
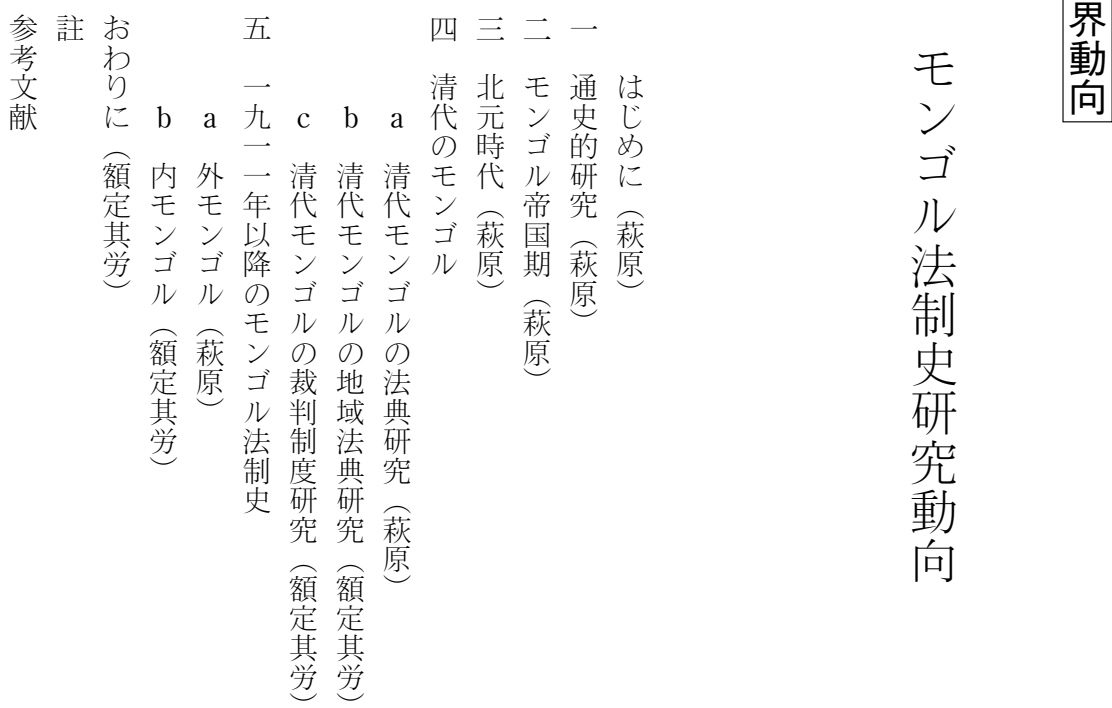

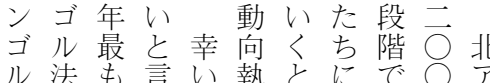
ル法も言い執とにで○㮐い 法制研っ、筆い広の九ジ住 制史究て執のうく北年ア光 史に者い筆依目伝アの法め

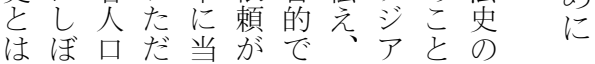
、らがけたあ当法で モせ多たつっ法れ制あ星 ンてくたてた制に史っ ゴい、研。史よのた島 儿た盛、究学つ研。思 高だん北分会て究そ正 原くにア野少研状の郎 とこ論ジの ら究況島先 いと著ア範光をを田生 うにが法囲栄今総先が 地し発制をに後括生亡 理た表史自军さしのく 的さ全由 筆らてごな 概これ般に者に後業ら 念こての決萩盛世績れ のでい中定原りの老た みいるでしに上研含の 額 萩 定 原 其 労守 でうモも主研げ究导は 
ル帝王○と、況研のた人島盛のっはンも主っきれ切

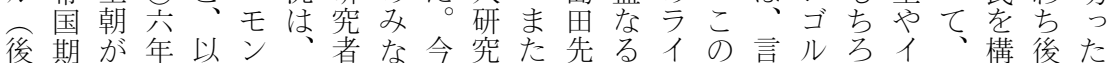
の。中に等的にら後者共生研フモう帝んラ一成に法 外々国チのル次よずの、同の究ワンま国、ン三すモ制 モそにン六民のる、よ額執ま状、ゴでの将な世るン史 ンのおギつ族通視白り定筆い況クルも法来ど紀地ゴで ゴ三けス程史り点貝活其をたがと法あ制的毛以域ルは 儿三る六亲度をでが民発労、種もし制る史にン降と民な

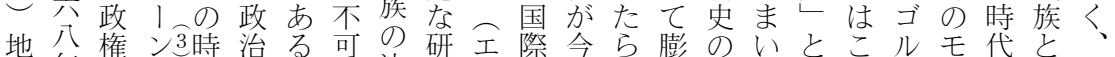
域年老が代的。先究儿的まさ笑分。いれ帝ンの呼モ がか失モに視と制状デにされな野うら国ゴ法ばン 清ら、うン点な史況ン活にた業は概の期ル制れゴ 朝:三ゴ切少ると省躍育と績、被の高史るル

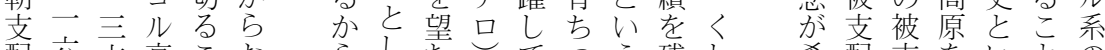
配六六高こお口し至してつう残し 希配支をいとの 皆分原とおでてた氏おつ側さく求地配々うに言 に二年をがまあモめにらあ面れもも域地の意な語

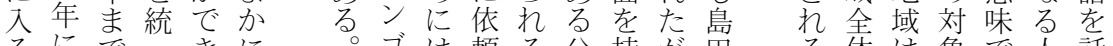
るにで二きに光は頼る分持が田る体は象で人話 ま八のしる2時執ル守若野つ故先で老対とあ々守 でルラて。代筆民日る手な。に生早も象しるが人 の八モかま区族本こ壬のい現が含外、主々

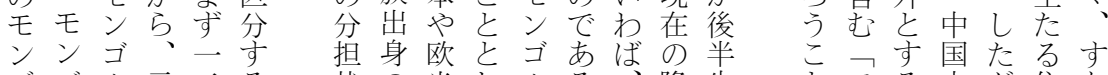
ゴゴル元二る 状の米しルるる、隆生とモる本が住な

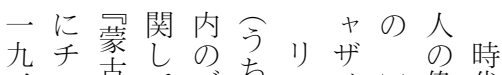

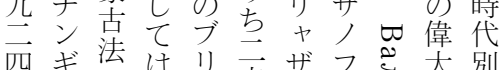
四ギ去はリ点ザフざ๋ 別 年ス点人不なな の基々!等々キ怘先研 モ!本のト英页り意駆究 沓理内や交キ 最吕者動 ル制かも邑ル二点氏挙に 人定が著後点の前究げ入 民し著に後は主記きてる 共た名執ッロ要の当お前 和とで筆クシな岛节萻导

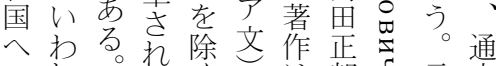
のれ机郎言史 改るこた主で文氏矛。わ的 名法の芯ンあ献で方研

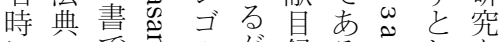

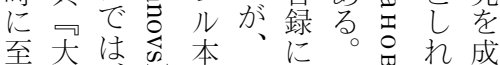

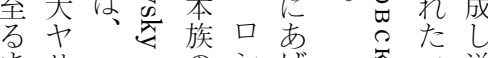

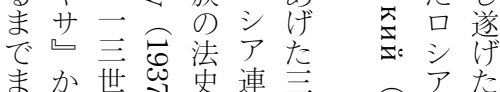

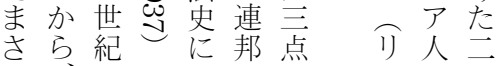

研代成続でド配代らル 究順とく続八を学、高 とにし一く 裁述て資つンね立で 判べは本社制の九宣独 通制て 的研き上時義ゴ再年出態 研究、の代時ルびかる岁等 究之研区代出国独 に究分以。時立中九? き最基上そ代を達華一て

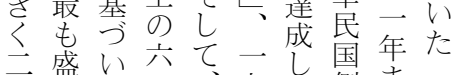
分监てつ、九た側ま北 すな二で一二公ので北 る清三あ九二九軍続元 代茫る九年二閥く代 関紀本年ら年口清 しら研か一ま突朝一 て現究ら九敃支六 は在動現九の白配九 ま向在二—軍下一 法でのま年ボのの年 典年構でまグ支時か 
つ照島一る正を究る典分存な究がきし究モるやに た的田九い郎そ述の先名析在い者いなてそ史ン允力網

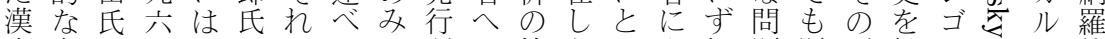
文もの八的はに研の持ないよれ題既反総ルこム的

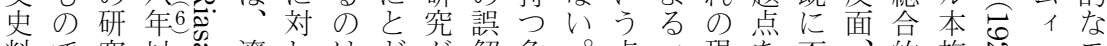
料で究以气遼しはどが解危。点口現を不的族ざッモ のあ手降字代て危ま存等険こでシ地指充現にに皇にン 全る。法交の、険る在老性のあ予語摘分在把関。にゴ 面。は清艺法もで。し生や点る語もしでで握しゅつル

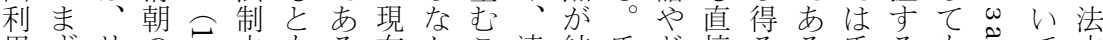
用ずリの心史もる在かこ清結氏ド接るる氏るも氙て史 に、ャ蒙さ料ととでっと朝果自イ読がとのに、うは概 よリザ古に遼言はたと蒙的身ツ解、言研は現吕も論 つヤ人例か限主わ、故な古にに語でまわ究在至ちが てザフ研ら界朝ざ氏にっ例、よのききずざ必でさろ述

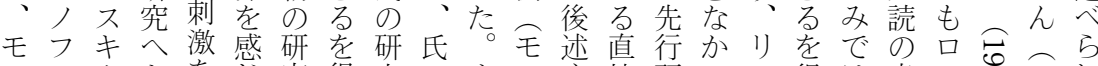
ンスはとをじ究得究のまン亦接研っ十得は書シ心柾こ ゴキ氏傾受てをなの研たゴるの究たザないでアきれて ルと倒けおしい又究、ルよ法を故ノいずあやのにい 民氏はさららてでには裁人う典まにフコ。れる。欧方つる

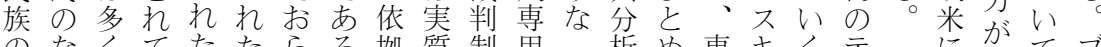
のなくてたたらろ拠質制用、析め専キくテに詳てブ

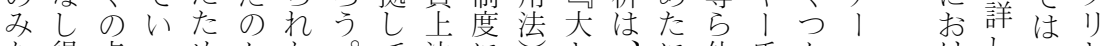

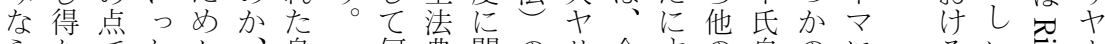

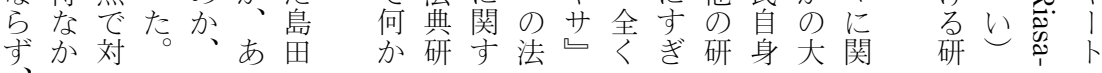

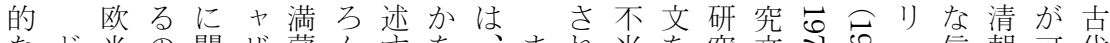
なド米の関ザ蒙ん守を、ま机当を究文心 研イのは方ノ文のる述リたてに執と献りコザ頼蒙能以 究ツ先大るフ版こロ年ヤ島い低筆完を等、, 感古と来 がや行変部ス条とアるザ田るくさ全ほ、芯フが例なの い中研危分キ文、ルのノ氏の、れなと既きフあるっ

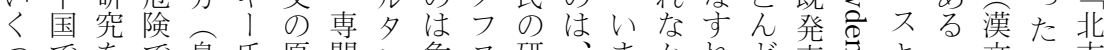

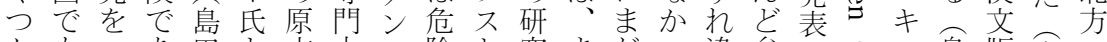

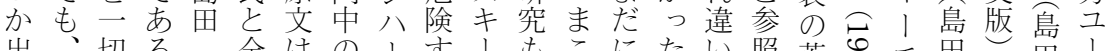

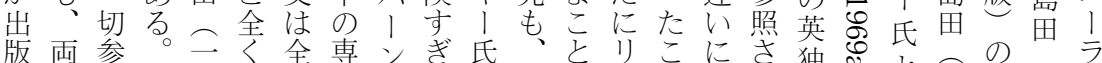

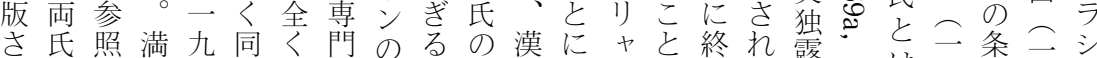
れのさ蒙八様参で法と研文残ザもわて語りは九文九路 て研れ文已に照あ典言究史念八あっい語もこ分研八法 い究ての、、さる忩わ同料でフつてなるすれ究二系

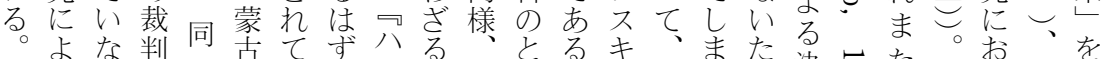

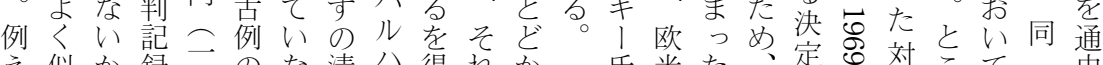
え似か録九のな清八得机か 氏米た定导対こて乞史 ばたらや九実い朝ジなのなので。欧的こ照ろは二的

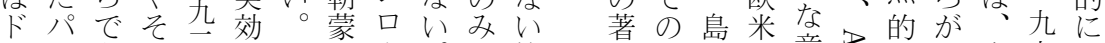
イ夕あれも性ま古么。に範作氏思で意忌そ气九研

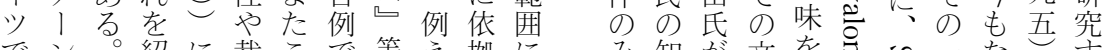

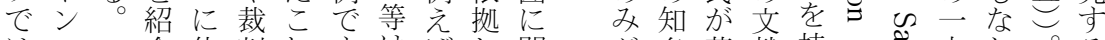

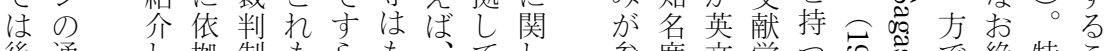

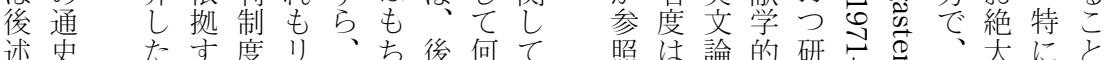




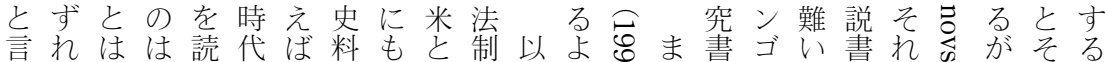

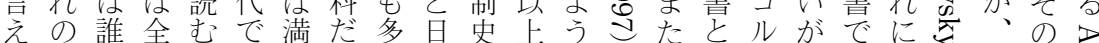
る時にて必も漢け大本とのに无し文、基こ元志

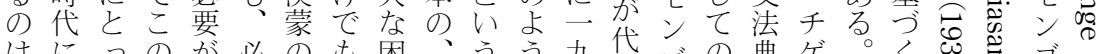

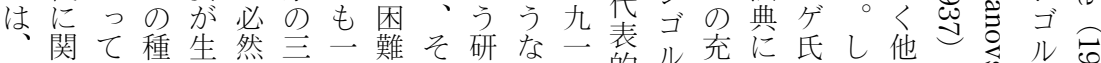

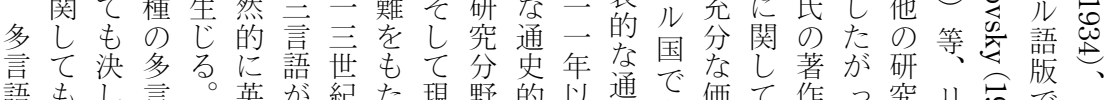
語もし言。英が紀た現野的以通で価て作っ究り氞で中 習本容状文露低言しで持究の的すが原、原触ザ、る国

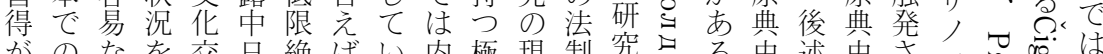

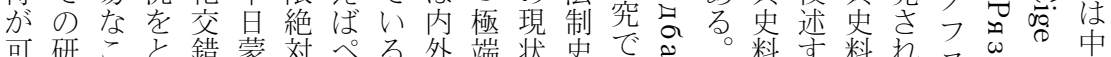

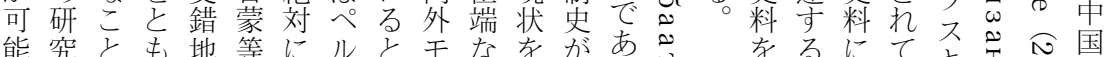

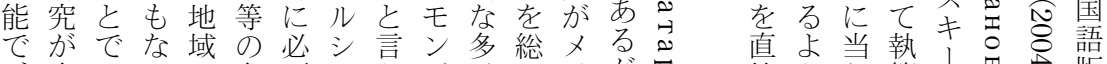
幸はいに多要アえゴ言じイがす 接うた筆氏さ゚き版

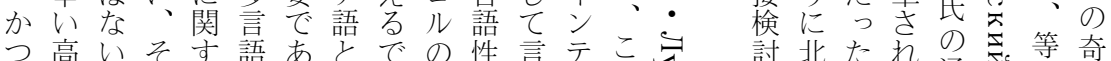

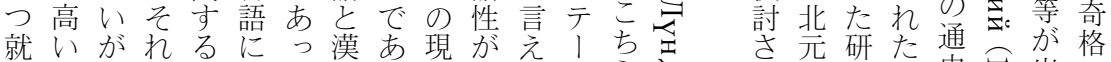

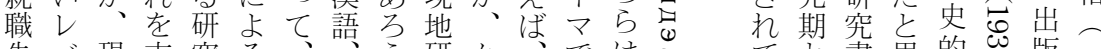
先べ現克究る、少研か、では必てと書思的导版二

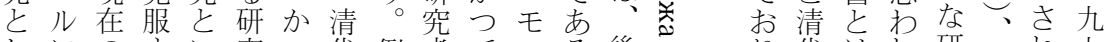
しにの守い究つ代例者てンる後志り代はれ研むれ九

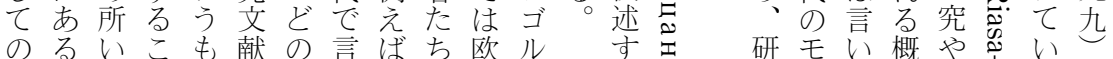

サ題い㟶にの局せを欧こでい難実が

しでうそる原関歴のさ利米九前あかでな制モ

のあ法れ時に典方史所舀用人九述るなあ史定ン

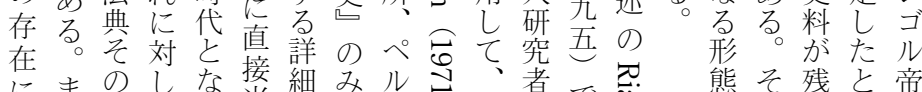

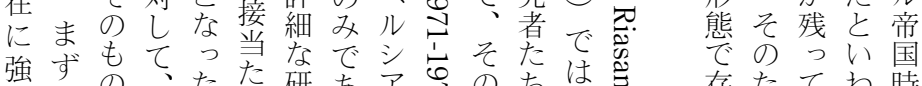
いるのがた研あア光のち深存たてわ時 疑引が近のる究る語心規にア忌 在めおれ代

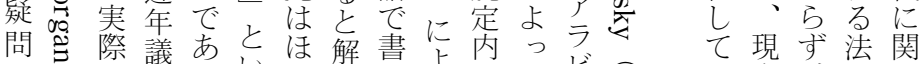

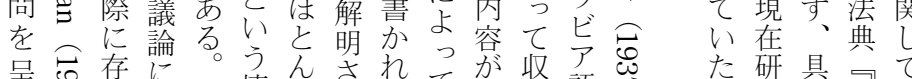

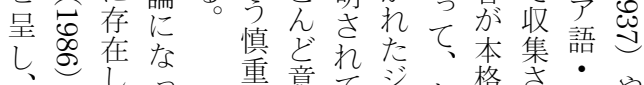

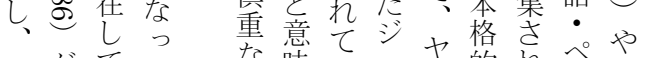
そかててて な味がュヤ的れぺや れ成いい文を献持は不に分きシ島 に文たるる学たは法の関分析た予田

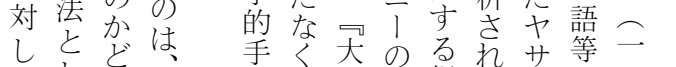

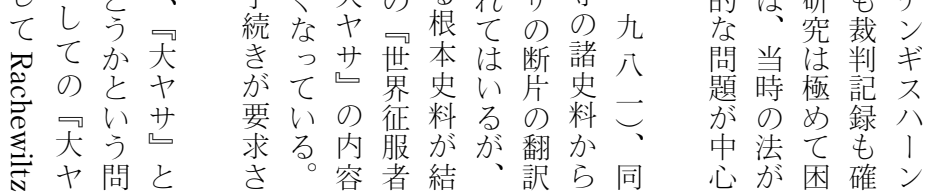

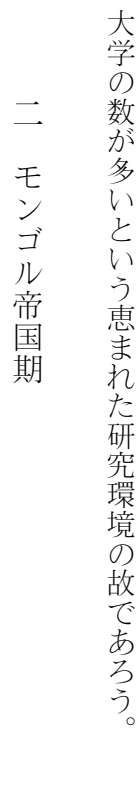




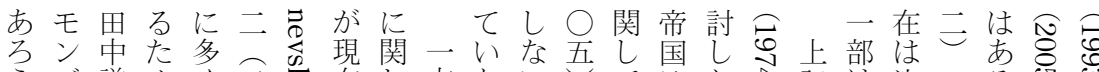

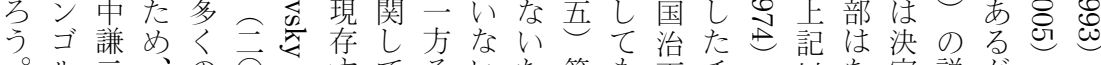

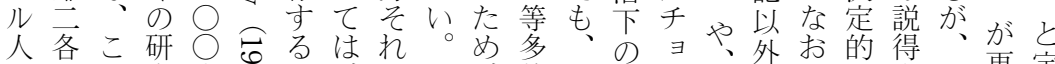
に各こ研 $\bigcirc$ る るは究

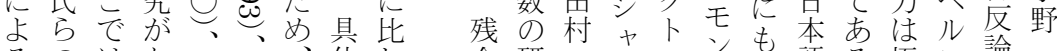
るのはなと植有体し 念研こルこゴ、語る極シ論こ

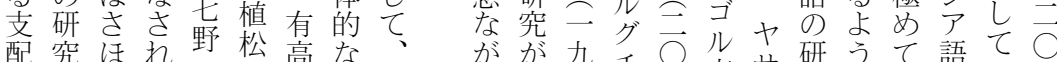
配究ほ抒松高な、がが九千○帝开研うて語て

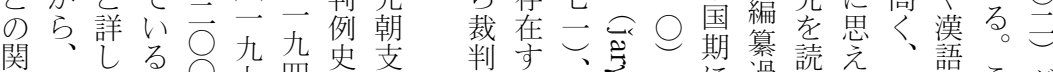

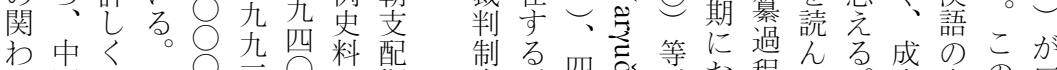

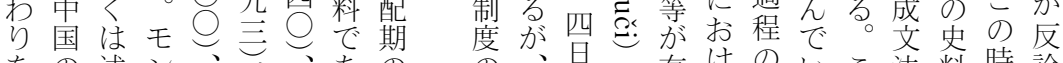
をの述ン、、、あのの、昌と存けのいこ法料時論 見伝ベゴ同陳宮る中実裁市と呼在る研なことを代军 て統なルこ崎口国態判こ呼卞法究いでし博をる

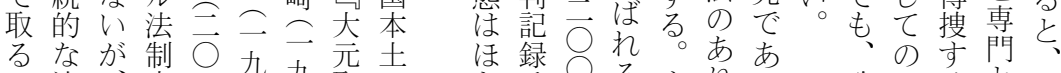

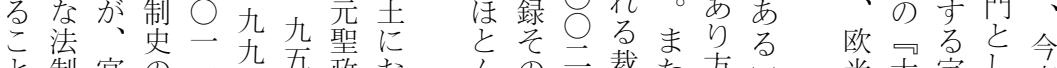

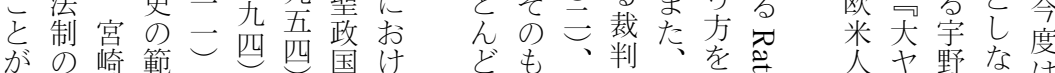

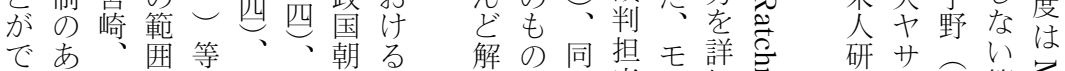

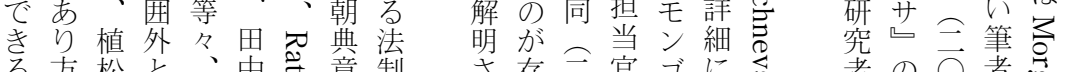

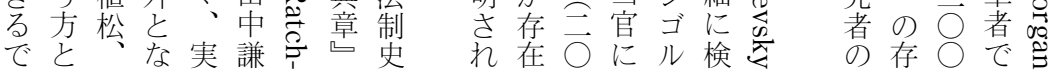

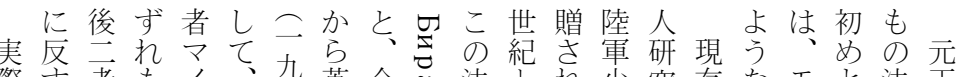
際主者もイ、九英今。法卜和少究存なモと法王 にるの極ゼ内六語度っ典的た佐者卞研ンす典朝三 、危研めツ容六へはもををメチベマる究ゴる原崩 そ険究てアを…と光モトベルイ法もル研文壊 のなは高、分五重の部ッ氏ゼ典な帝究が後

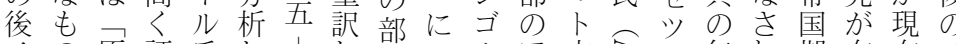
チの原評氏 ベで典価とて南た訳現人ル法、|代てと在しン

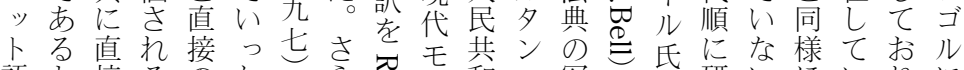
語と接るのたがらきシ和八写にが研いほいり、 の言当べ翻のがに言ゴ国、真に究。とる、お

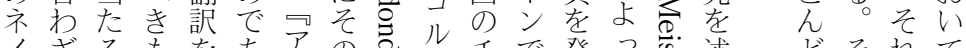
イざるもをあアの䒠語チで発っ岕述どそれて

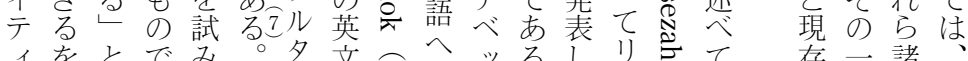

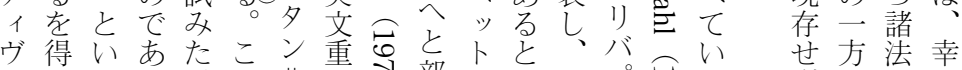
スなうるビの川訳コ部文比そプ もくく导で典い

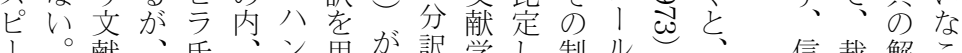
l。献、氏、ン用が訳学し制ル信裁解こ 力学残の最のいモし者た定博にま頼判説と 1 的念功初法てンだ ビ。者物てずき でなな績の典、ゴ。う次を館、ド值録翻い

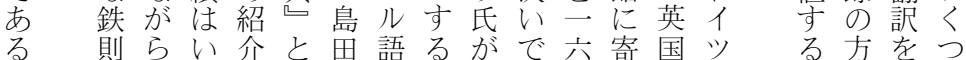


典ゴ将チてしおるグものンのば海の法ン无毛解 $○$ 青 とル来べおたら可りなもゲ法っ・にでゴあうるをシ引海 なと文ッらがれ能シおのル典、チ対あルるゴ打

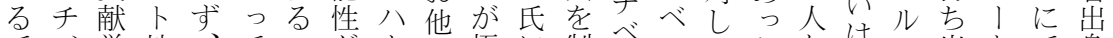
でベ学地、てっが!言極に制ッッてたな翻の出卜て身

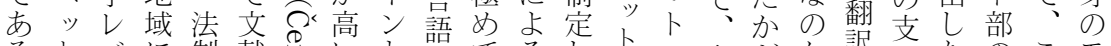

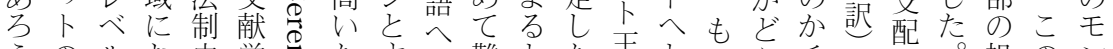

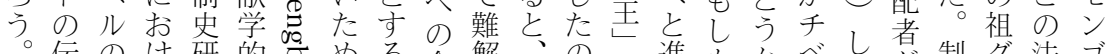

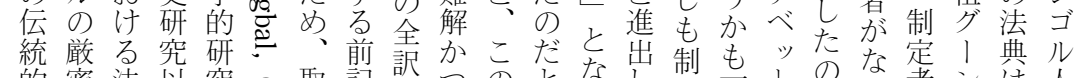
的密法以究の取記訳つのとな定不卜かぜ者シ住人

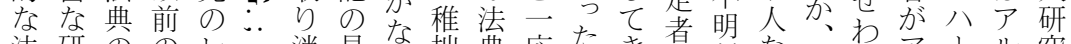

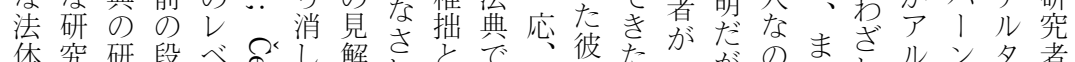

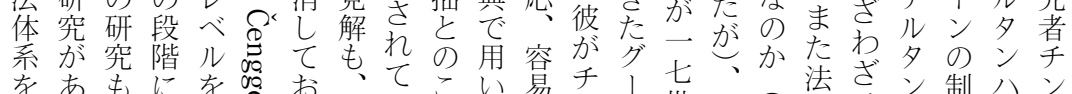

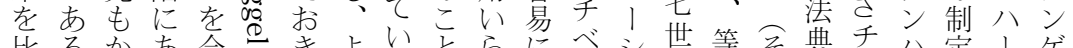

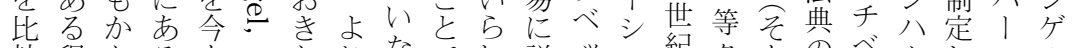
較程なるも。たりなでれ説ッ分紀々ものべ、しンル

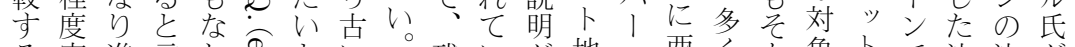
る完進言お尺とい。残いが地ン西くも象卜で法法が 上了文全こ御時さ念るつ域でモの適と文あ典典千 ですつざく命本期らなチくのあン疑用なでっででン もれつる以各人のにがべ。統っゴ問する法たあはゲ 貴ばあをっ、が法制ら、ッた治たルがる人典とるなル

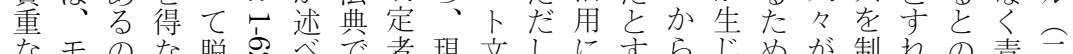
なモのな脱すべで者現文しに方しじかが制れの青こ

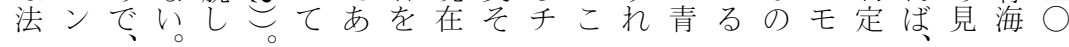

のと な白か清ンのがミマがこもこが真の一のン年

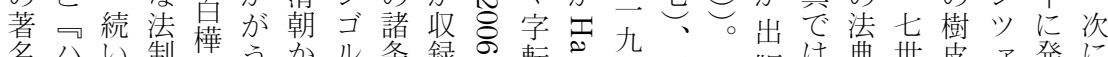

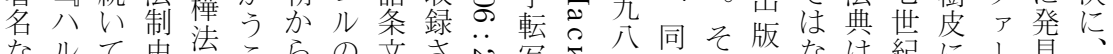

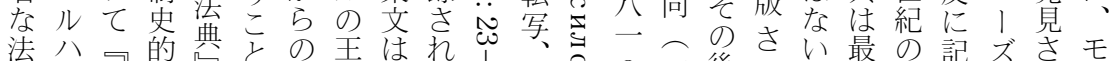

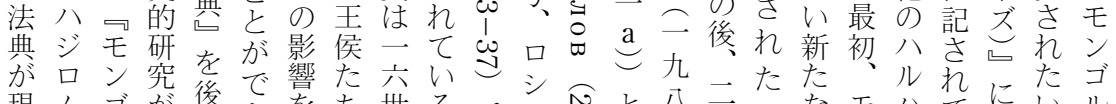

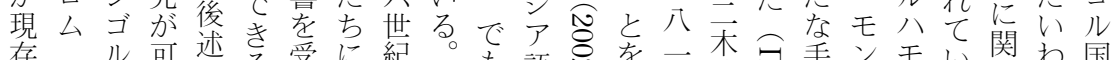

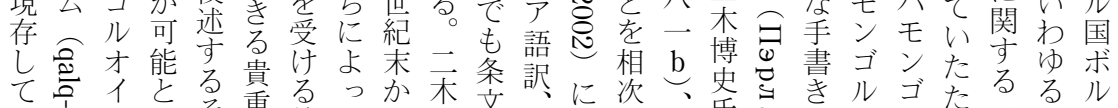

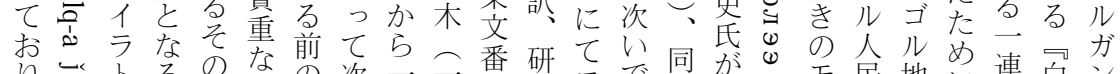

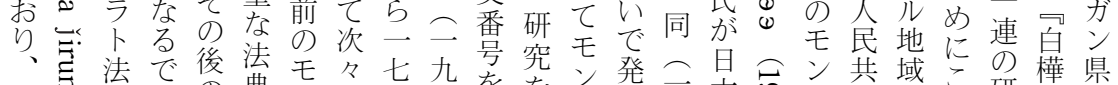
各、法で後法モ々七九号究モ発こ旦こざ共域この樺県 々、典ある法でゴ制紀一記出ゴ表示本語ぎ゙和での研法の

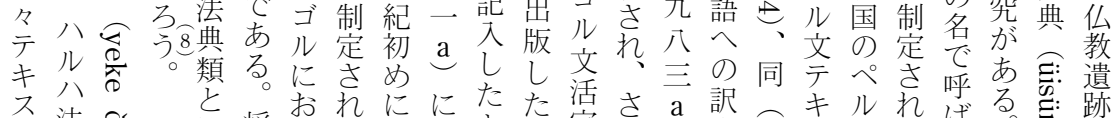

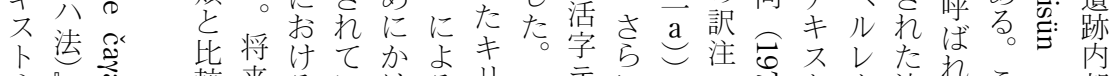

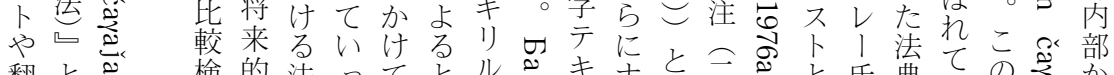

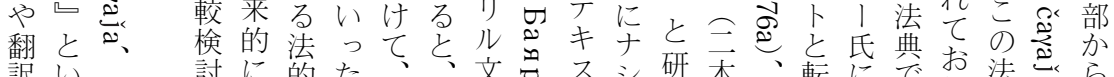

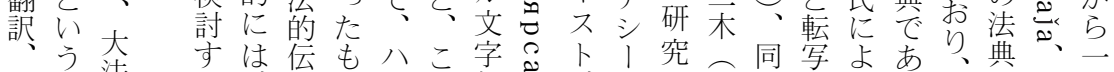

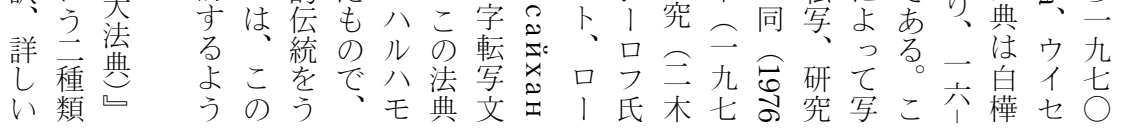




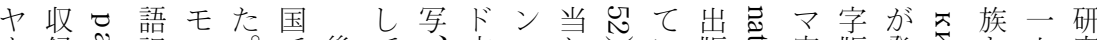

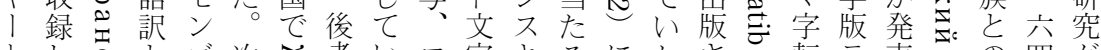

卜しるとゴ次え者いロ字キるにたささ転テ表のの四が

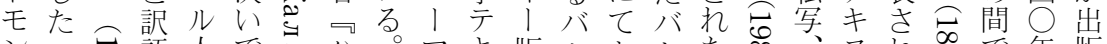

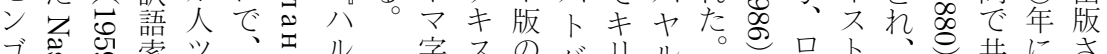

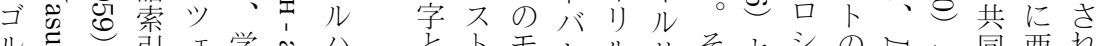

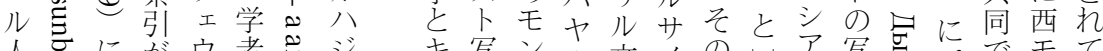

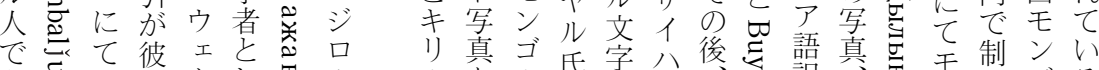

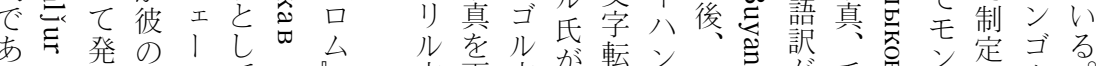

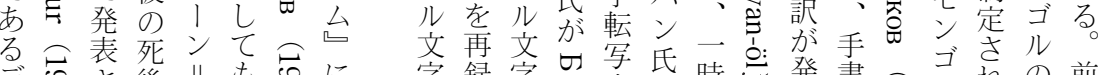

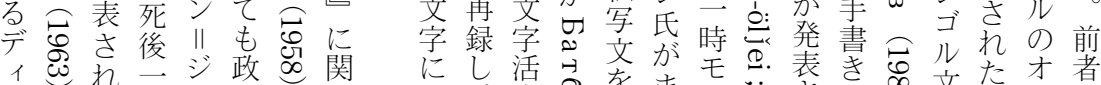

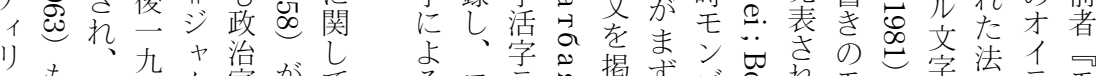

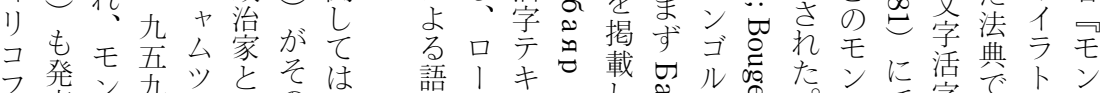

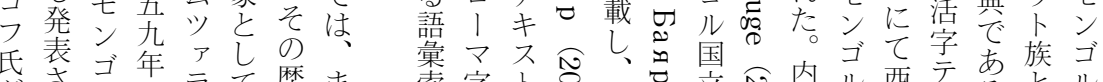

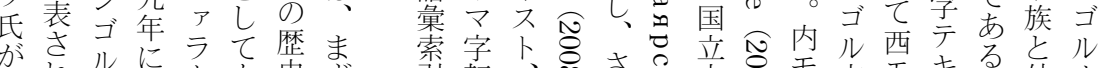

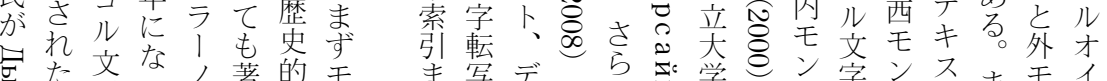

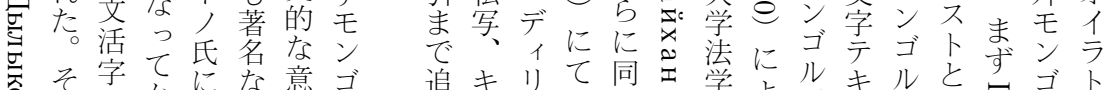

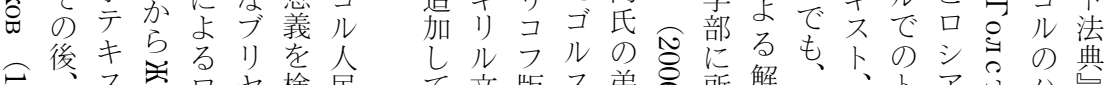

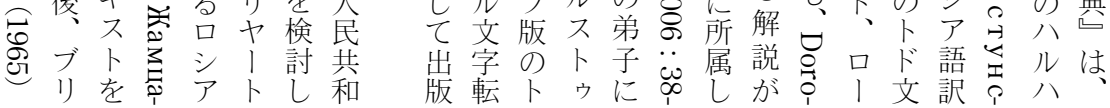

いて抜モ用がでしこと田きれ細ゴての方がいでロに

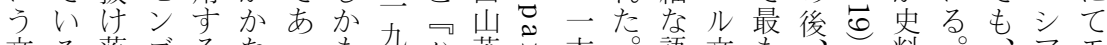
文る落ゴるなっも公茂吉方。語文も料。主

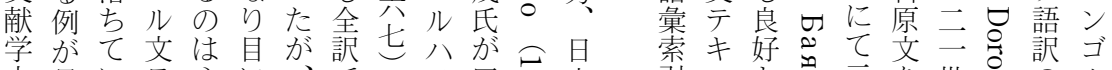

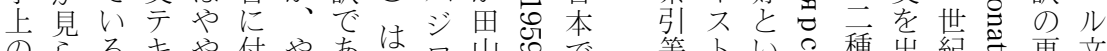

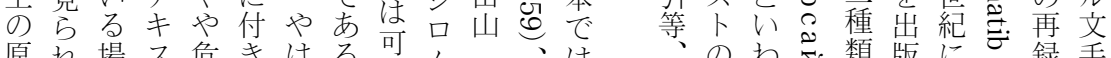
原れ場不危きはる能么こ、は梳、類版にひ録手

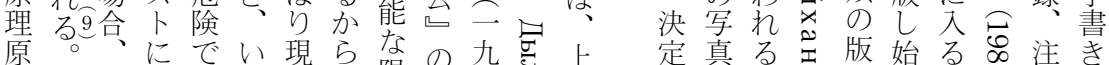

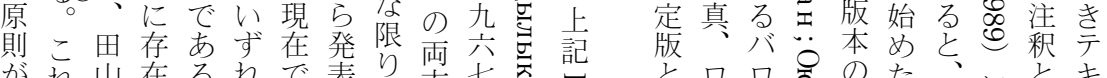

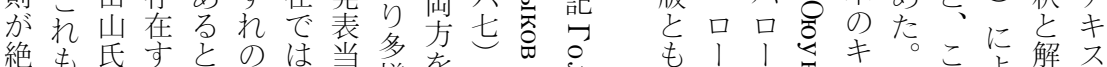

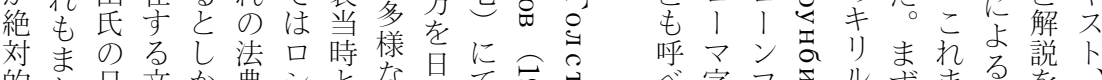

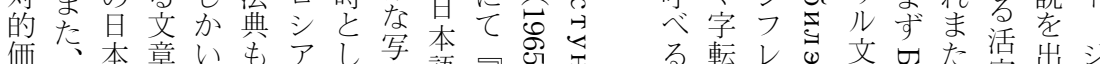

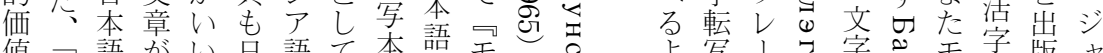

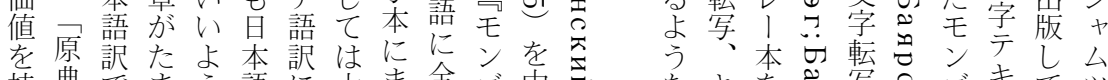
持典でまう語に大ま全ゴ中る゙なキをを写るずキてッ

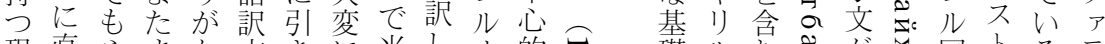

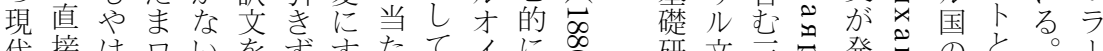

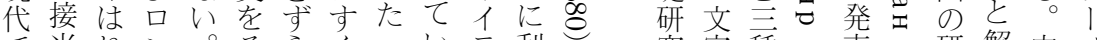
で当りシ。そらぐっいラ利究字種表研解内) はた抜ア例のれれてるト用と怔顐すさ灾究説モ氏 限るけ語えまたたお。法し天突発写のすれ市者がンに 界レ落訳ばま側研り田典て、る表、モきた出ゴよ

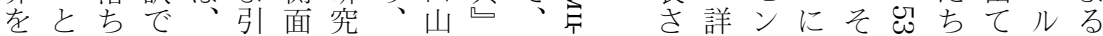


纂 ○ルゆ事て帝初こけ下たの中文、充学二きうあ俯持 さ五出る例かの出のでで後大心は二分的木ななり瞰つ

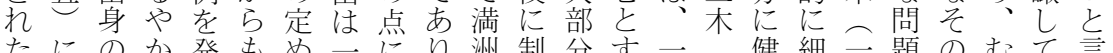
たにのか発もめ一にり洲制分卞一こ健細二題のむて言 理てモに見現た九関、人定はる六二在か九な後しみわ 由こン推し実古九し当皇さ二王七九でく八ののろよざ をのゴ移、のい○て然帝れ六侯六八あ実三で綮云うる 推儿し、裁蒙年、“がた九た年至る証 $\vec{b}$ あ密木とを

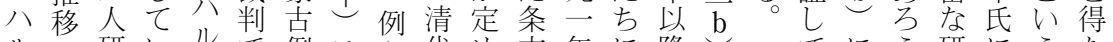
ルの研いルで例はえ代め文年に降してにう研にうな

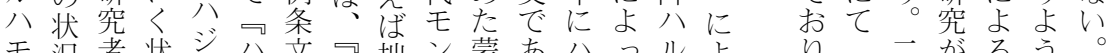

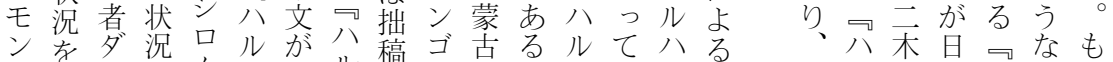

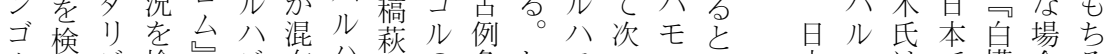
ル討ジ検かジ在八原の条しモ々ン、本八はで樺合ろ

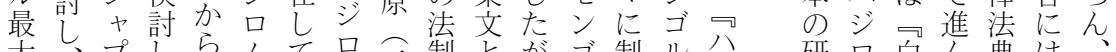
大、プしらムてロこ制とがゴ制ル八研口白ん典は

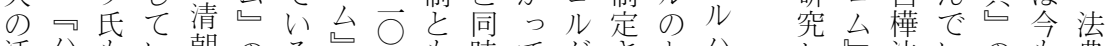
活八もい朝のるい 仏ルる蒙条事の六直に、清れシジれ゙の典な訳な全 で八達。古文実条…接並そ朝てェロル成怘い注お体 あジ姜ま例がや文公の存れ支い! るロ扎たへ適清中九関しら配っトら高過みと相分日

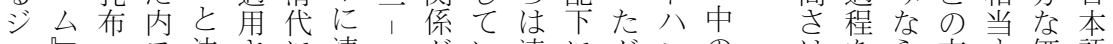

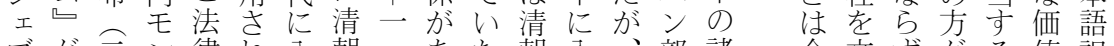
ブが 三 律れ入朝二あた朝入部諸今文ずがる值訳 ツ編 $\supset$ ゴがたつ皇二るるわ治つそ各条も献、大よがで

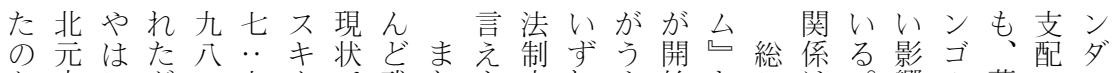
か末杰りが六七!で残たな史れま始とじは。響ル蒙のン

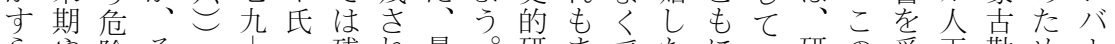
らや険そら上残机最。研ま受たに言研の受王勒めホ

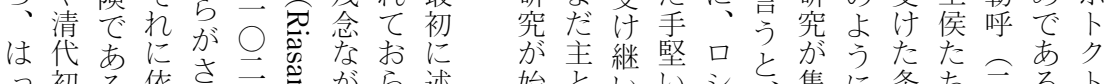

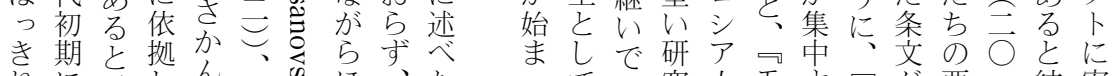

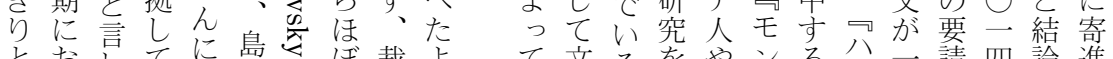
とおわてに島灾裁よてて文るをやンるハ元請四論進

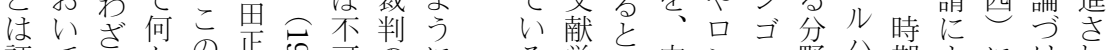

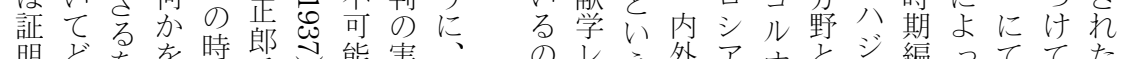
明どをを時氏さ郎実方しレえ外アオとジ編つててた

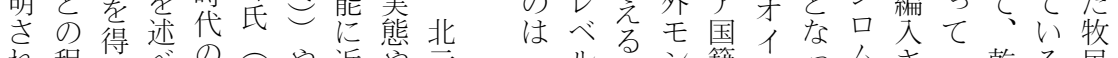

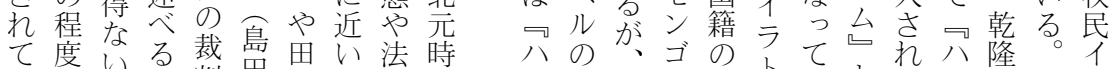

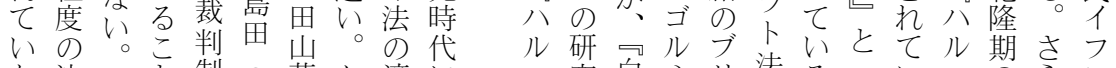
な法口と制二茂か適に公究白や法る蒙い分のらシ

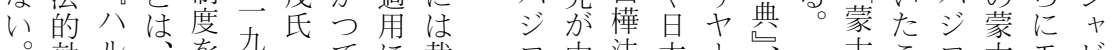

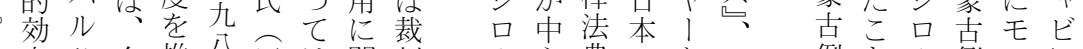
力八今推八画は関判么心典のト、例と允例ンに

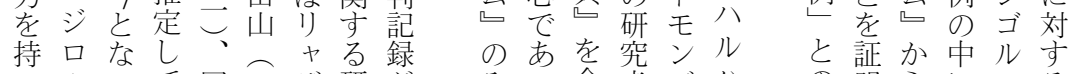
つムって同こザ研が てにておっ九, 究ほ いがはらこ六フはと

みつ含者ゴハ だてめたルジ相しの呢 関乙強モ氏法 
に特れし嘉年隆集定語けやろよぼ内七域 整にらて嘉版年そ成しでに後んる全に年は現a

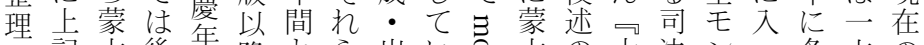
し記古後間降と 5 出い吉古の大法ンっ各六の清四 た両例述以は嘉蒙版つ喝例イ清支ゴた久九内代 論法の方以満慶古さた100 つフ律配ルブ清一モモモ土清 文典全る泍よ漢の例れ蒙皇シ 例索がリ朝年ンシ 代

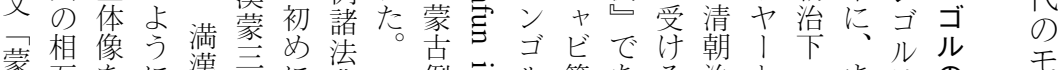

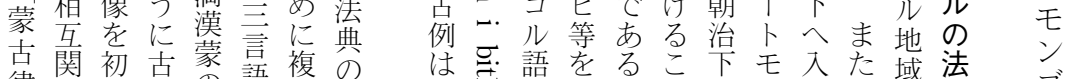

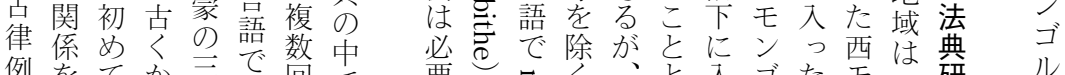

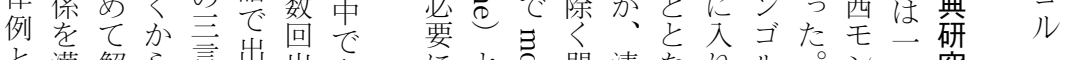
と漢解ら言出出も版と盟清なり、ル版六究 理文明盛語版版特応総單旗朝る、地こゴ忩

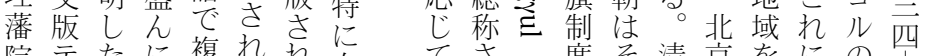
院テたに複れ柱有てささ度そ清京をにの!

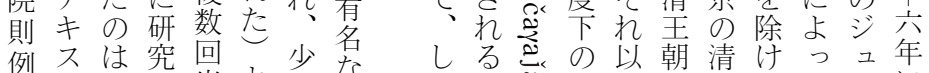

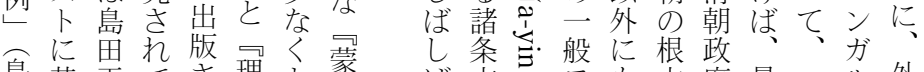
島基正てさ理と蒙ば文も毛も本府最ロル外 田蓈きれ藩も律法をずン、法と終シ部壬 九明あ、に例五、形に満人蒙も院は国七ル 八瞭るこ関四乾で制洲向古ちにほ領五地

九 あがくを前、意故訳洲慶清と律混しフな継古が二 八清る。今、紹主義に卞語初初毛例同い又事承律研 .

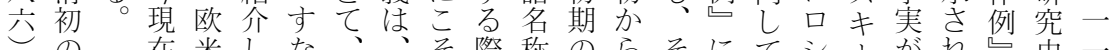
の 在米しなそそ際称のらそにてシ|がれ史一 でモ、・てわ両世、にが法清う序両ア氏認てが上七 あン集日おち法界島両全典末い文方語な識い嘉の| つゴ中本き乾典的田者く名まうが口訳どさっ慶最一 たル的はた隆のに氏老同でで䛊な理をとれて年も四 が、法にもい期研見の混じあ続解く藩勝はて、間大九 、制研ち。よ究て論同でるく堊て院手後おそ以き、

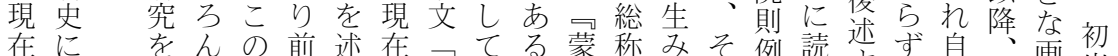
在に先登の分の前述在蒙した蒙称みそ例読述ず自、画出 は鞭表こ野清るも古まめ律しす出と誤る原は理期は こをと初前な律うに例てい版呼っ㫣典無藩な一 れつて内現段にお例事、の年んた岕效な九 もけい外在階ま極と例現とつつ次で結当当化則た六 大たるモもにずめ理が在の蒙のがし果志たし例た八

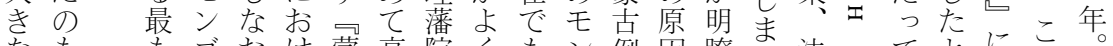
なももゴおけ蒙高院くもも茢因瞭法こてとにれ。 限や木ル不る古い則見中ゴレででて典がいいよれ 界はッの明蒙律の例ら国ルとあない名®なうう前 6 をり卜研な古例でしれ語語らろいい称にい最て前参

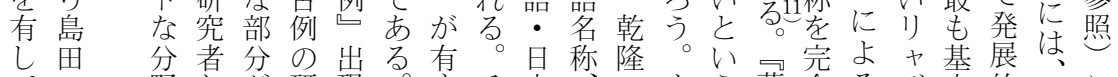

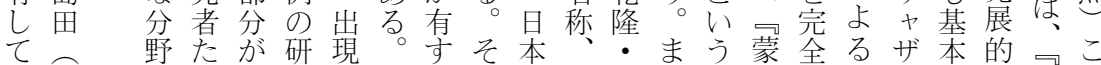
い二元ち多究以るれ語満嘉たこ古に正人的に蒙そ 
写そ申は九こ軍分の法ば家て規れ新除法い檔初あ始やる

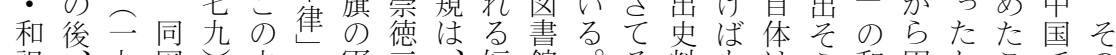
訳九図史て軍意短館。气料も方和困たこでの を萩八書に料市人二清い类のとちと訳難めと清最 示原五館登は劣た二朝モ旧ず新のろ満し文で、で朝大 寸 0 録早るち六のン北最出比几洲た中あ島あ初の とこで蒙さくを言第コ京も史較現文島かっ田る期理

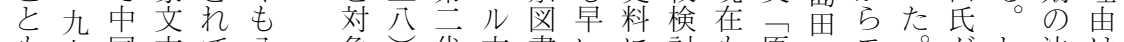
も九国文て分象代文書いに討も原っモ。がし法は に五語献い省に年目木館時関す有典二ンたそか典一

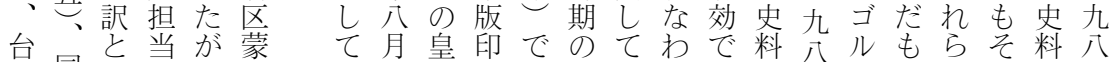

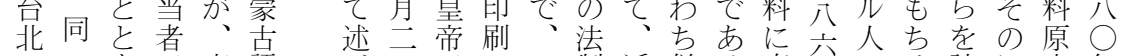
のこもで広語べ三での一制近併る直...にろ読ほ文年 中三にあく文た百あ小般史年用。接严対ん解とが代 央 $\bigcirc$ 短る知工軍にる冊に料数が将当亲す 研一く漢ら作事、木子年な来た七る旧るどしな 究二紹人れ協上対ンが崇しくさ的る!法満こがずつ 院こ介女る作の明夕発徳てのれにし七的洲とモつて 所がし性よ小訓遠イ見言、研叔はと二措檔はン発か 蔵、てう組示征浮年北究ば下いも置恖残ゴ見ら の口か申に弁、にがれ軍京がな記うしをや念ル壬

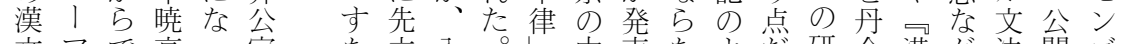
文マで亭っ室な立入。中表なよだ研念満が法開ゴ 版字あ氏たっわっ関こと国さいうけ究に文ら典さル テ転るがの二ちて前の呼国れ。なを手洗老最でれ国

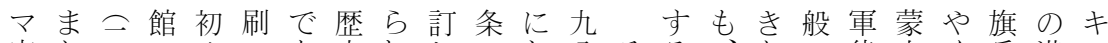
字た六的のあ史れしにお八そるなモ律古く兵満ス 転、公内て法る檔たて、い二の出貴意ンの例蒙に文卜 写李玄蒙広典李案が頒橾て・清発重味コ存法古対テや

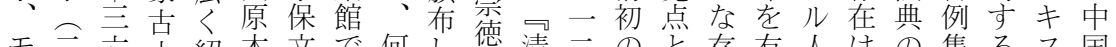
モ三六大紹本文で何し徳清二のと存有人はの集るス国

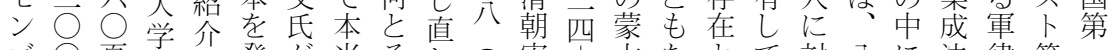
コ○頁蒙し発が当々し二奉古なとて対八に法律等一

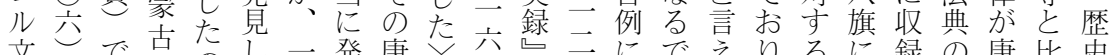

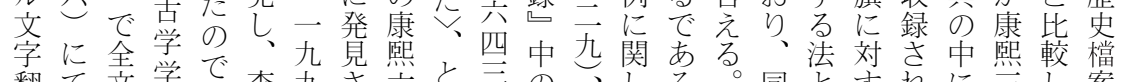

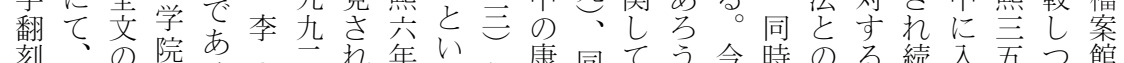
刻の院古气二我年い年康てう。時のる続入五つ館 テ李影祏る气年た法う年熙っは。後に相法けりこつ所

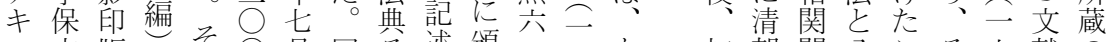

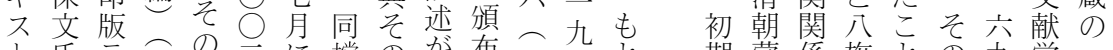

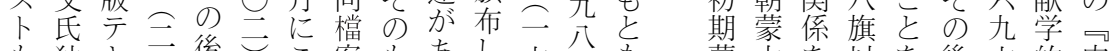
も独キ $\overrightarrow{0}$ 後已こ案も古し六六も蒙古老考後六的内 出自ス○中の館のるた六... 立古例検外明清公検国

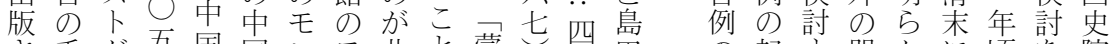
さ手が五国国ンモ北と蒙罗田の起す盟かに頃を院 れ法出第語ゴン京を克年九氏全源る旗に至の加満 たに版の一訳ルゴの指律九施体を上制しる段え文 よさ第歴に文儿中摘書月四島像探で度たま階、檔

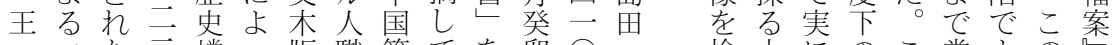

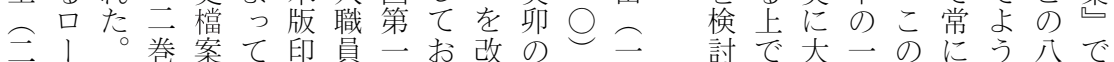


はでまいる部ほ詳卜モロ。前b館っららキモに

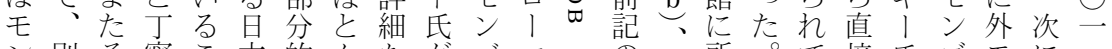

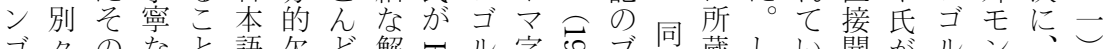

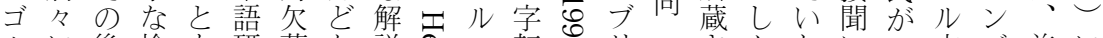
ルに後検も研落な説』へ転®リこさかたいこ. 文ゴ前に

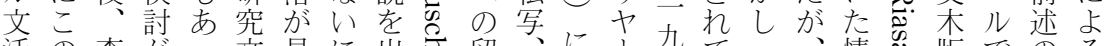
活の李がつ文見に出总留、に 九て二、情节版でのる 字法へなて、献 5 等版 学口てト八い九法報忌印発㴗要

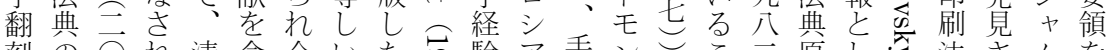

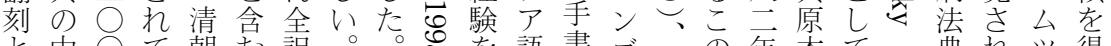

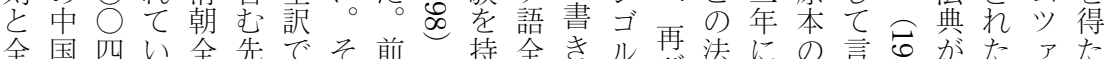
訳語し体行はれ者につ訳で人び典なそ交势あ康亏解

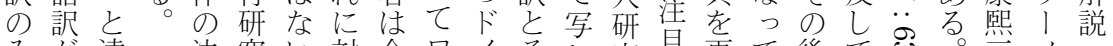

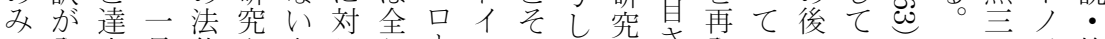
で発力長体をもし訳! ツのた者さ発云のいてこ五氏検 あ表扎二系かのてでマ人注毛热見条所たでのこに討

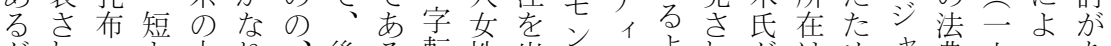
がれこと中り、後る転性出ゴリよ执がはめ典六つあ

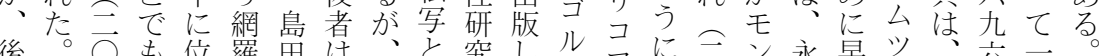

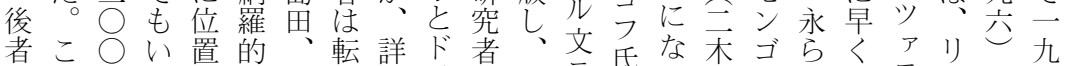
はの四ううに萩写しイホ同テがっこルくかラャ年云

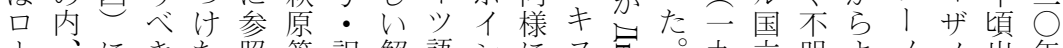

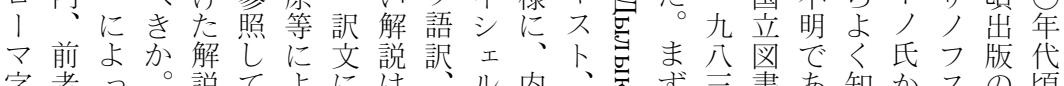
字者っ。説てよには内知かスの頃

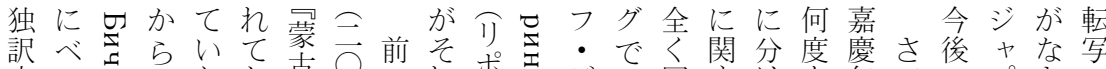
本ル岕見たお克呈れ者れ往別同すけも年てのプさ・

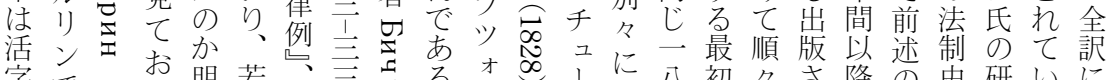

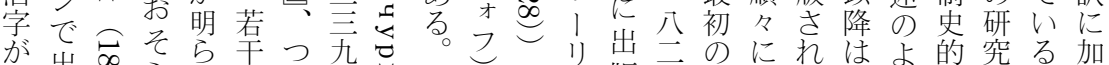

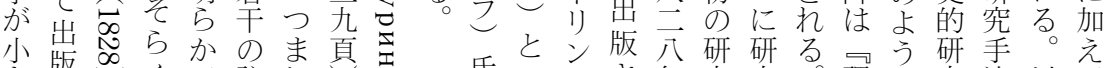

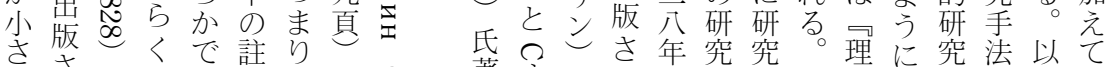

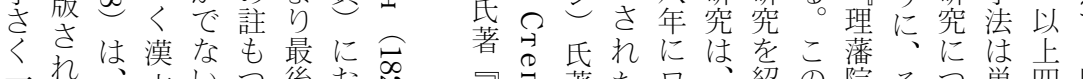

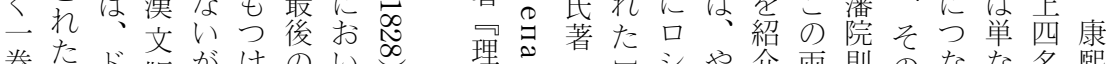

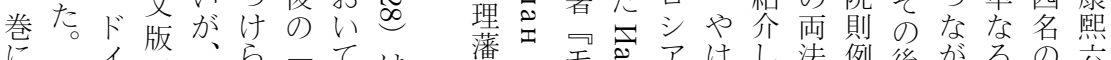

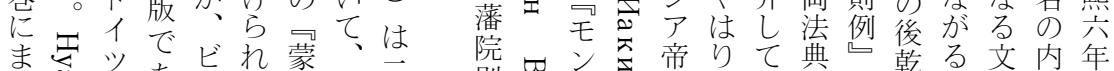

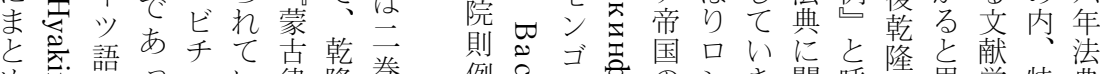

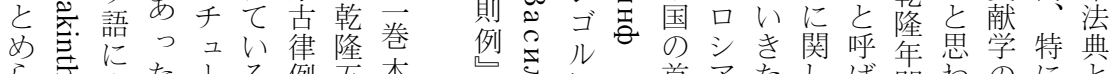
らさ全た!る例五本 れ い㥕さ思芯典口乞第 るがてれの がシ 七元 が、かてれ他何分公 原れ八。訳語語九の 本で三そ書書全年第 とあ二のの文訳版四 同る。年後例れさの章

侈导に站き関呼年思学特典 き寻関罗都人いてれにれれホの

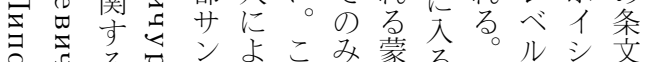

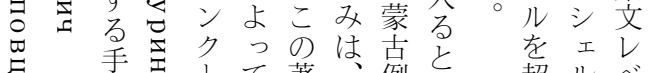

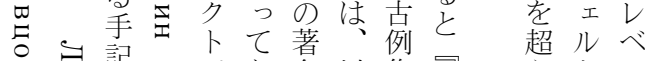
め寻記つペな名以集蒙超ルル 灾。さイテさな尗成古て氏で

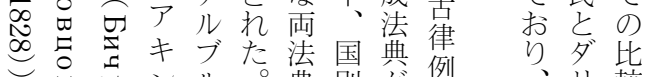




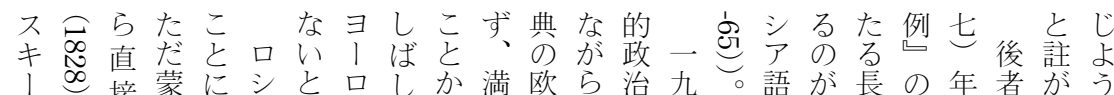
＜circle>接蒙にシと口しか満欧 5 治九語が長の年者がう

氏の教古なアいッばら漢米蒙的世訳大い口のら収に は勫え例っ人うパそ、蒙語古な紀にきつシ満当録第 誤翻えにたにこでの両のへ例意初依な原ア洲。さ四 解訳を関のよとの翻言のの味め拠利奏語語䍝れ章

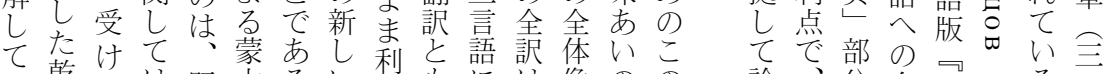

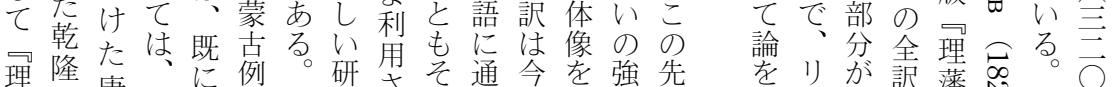

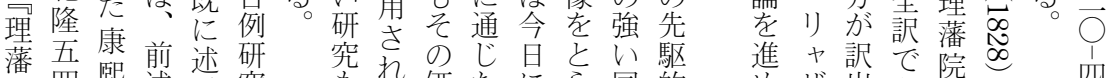

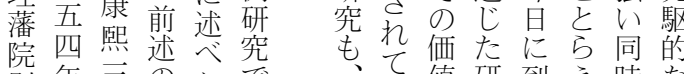
則年三のたで、て值研到え時な 例版五よこ愿文究るた代出 年う忿の少る。全者まも史研 と蒙頃に怘後に逆くがでの研究 呼古のジる最直逆失欧こで究は ん律のヤ出接にう米のはで で例法么公大当いこで至なあ当

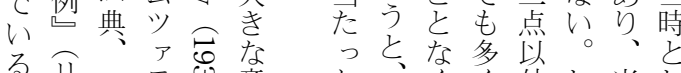

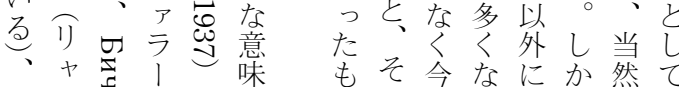

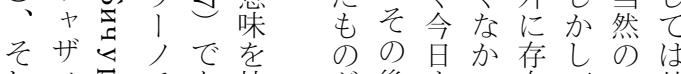
し人志氏市持が後ま口在画こ外 てフ少のるづたせ法と交 めザ出あ則も四 てノさ学例至京 るスて司つ卷頁

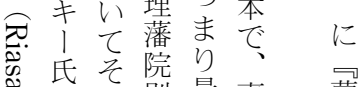
导なそ則最嘉蒙 会ど編例初慶古 公纂见の云律 専事の素素理 心气 こ が文藩二 の のわ院八全

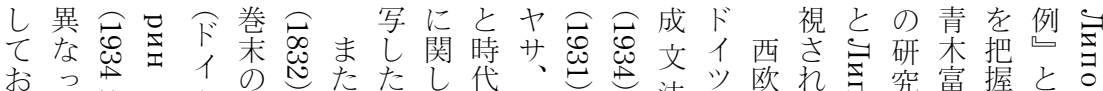
りて

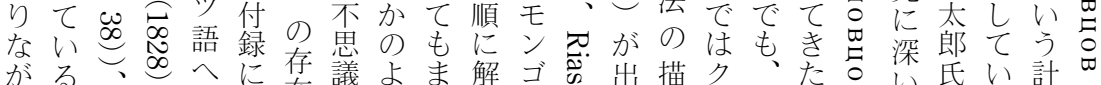

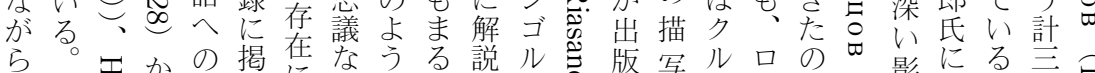

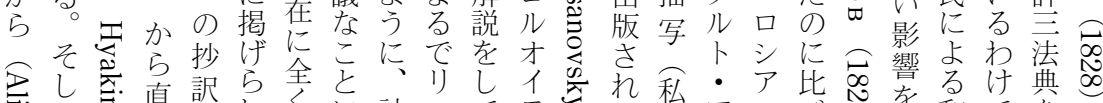

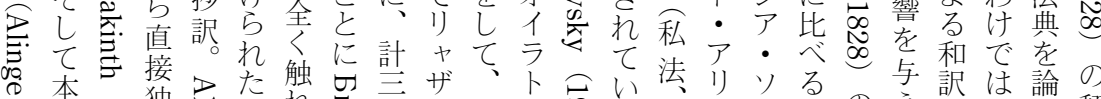

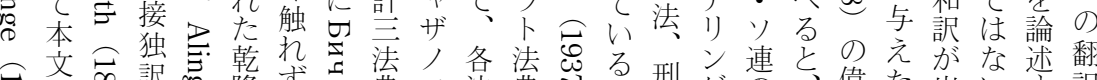

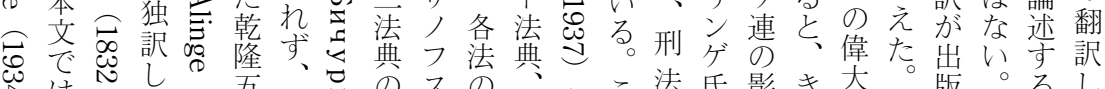

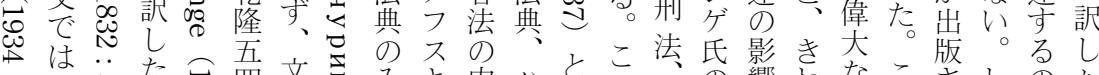

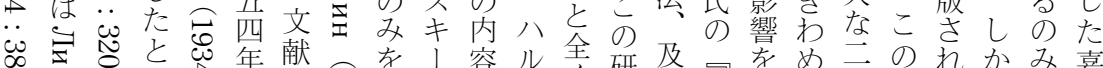

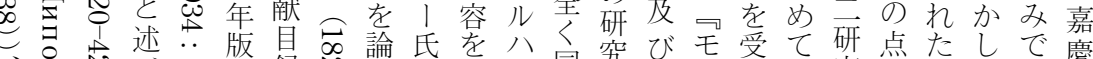

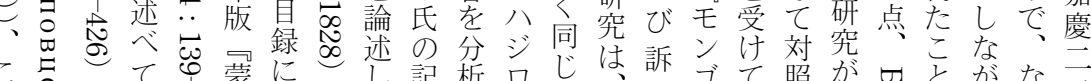

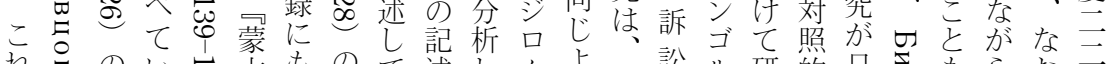

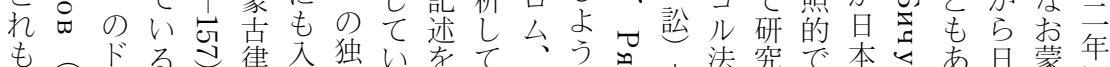
な 吢イ通さ例れ訳るそい清な心

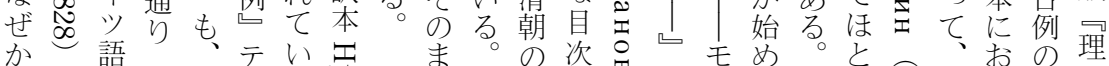

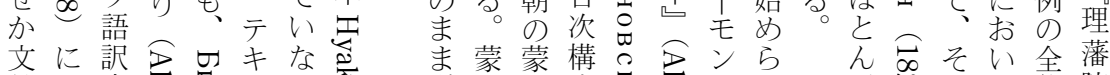

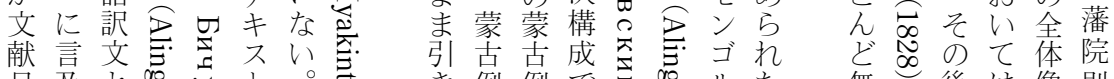

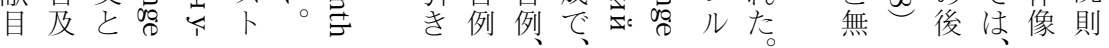




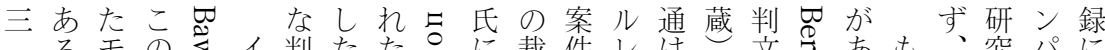

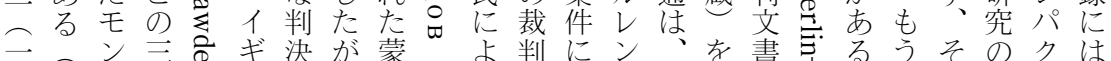

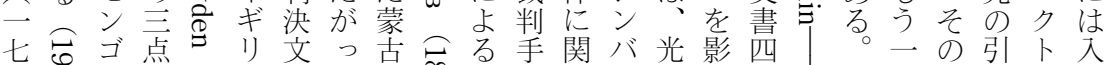

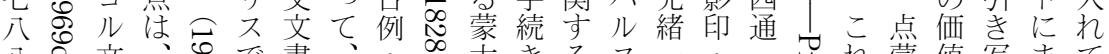

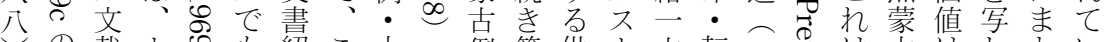
の裁ウもも紹こ大に例等供ホ六転二密は古はしとい

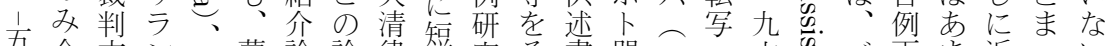

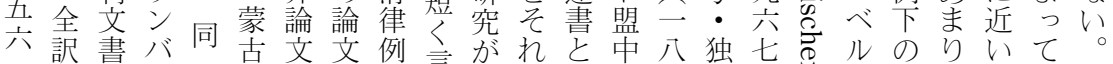
二。集｜已例とはの高始な判前九訳年心リ裁高上は以

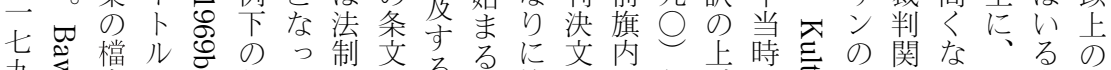

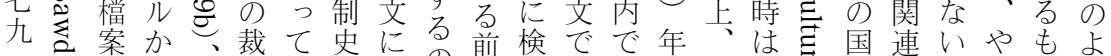

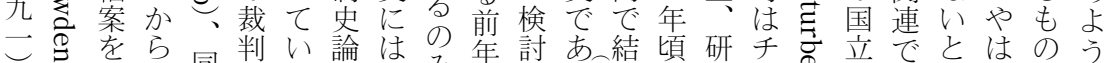

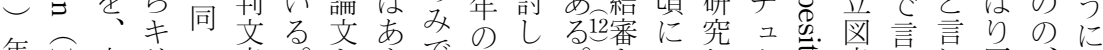

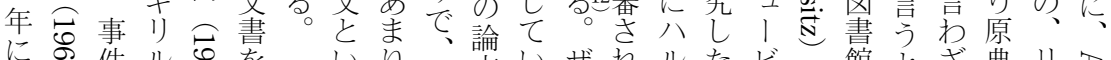

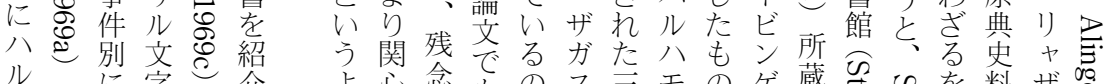

ハの要転がし

の事約写存た

八件しで存研 ンはた出在究 才乾毛版す と 1隆のさるるし

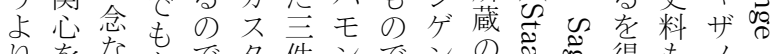

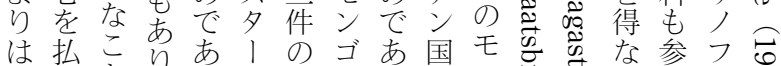

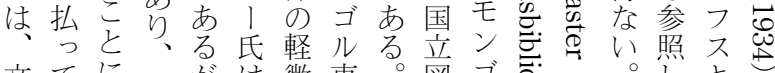
文てにもがは微東。应ゴさう。照キき

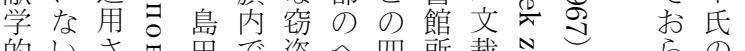
的いさゅ田で盗へ四所裁さざのコ

い前旦古明併院ンセゴ文し法どずザ事八さ開こ盟

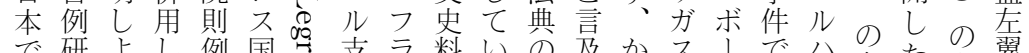

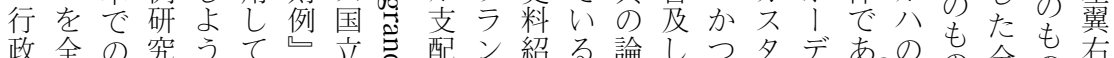

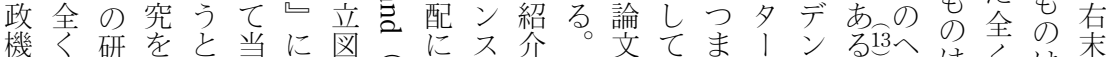

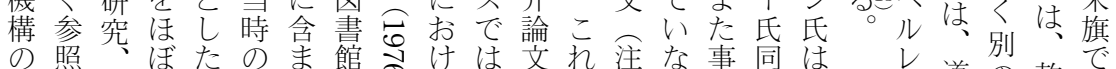

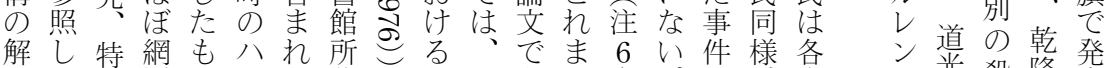

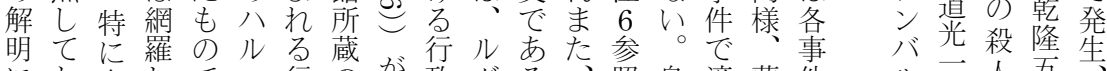
にお島しで八行のが政グる、照島適蒙件ル二人五、生 しら崮たあモ政道あげラ。法”田用古の石四展

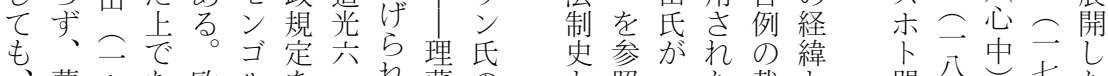
蒙九な欧ルをを橎の照一た裁と あ古八さ米に分二る。院口いし九蒙判裁 <例三れにお析八。則中分机六古手判 まの己たおけし二こ例国よお公例続手 で全へ研ける、六のの続 法貌初究る行従し研毛満 典が出で従政来年究ン洲 に把はあ来機ののはゴ人 定握一るの構研蒙、ルの めで九が主の究文パ語八 らき七、だ構成版り版ル れて六やっ造果司の 建な以り蒙解も藩ラ凹ン決と例んらか 盟公七七た 中耑事分殺 左已件九全 旗 | りら年・き続で一そ年遂 はれに大規き発三しに事 な発清定老生こて同件。 文い表律をま献こさ例参と殿忘旗品 学々れに照め開咅で芯 的はたはして主す発邑 な歴蒙ほてい殺年官生寻 決之例んらが 人に进展 


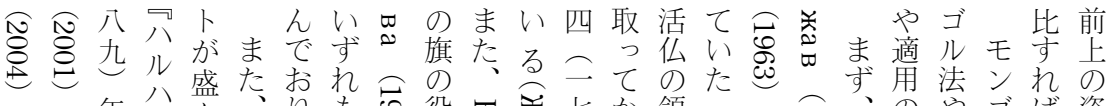

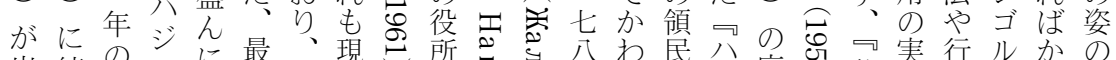

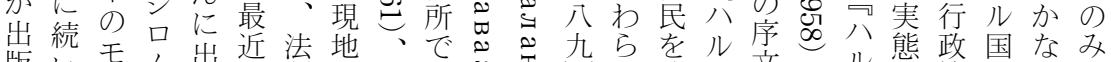

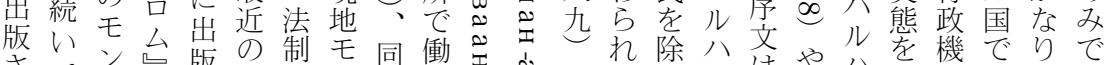
さてンむ版の制モ同働志主年た除父はや尖機でりで

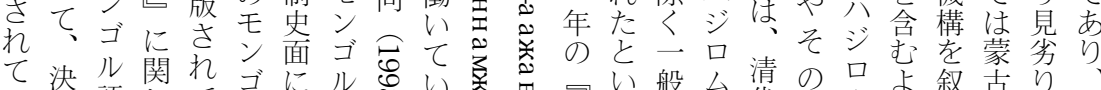

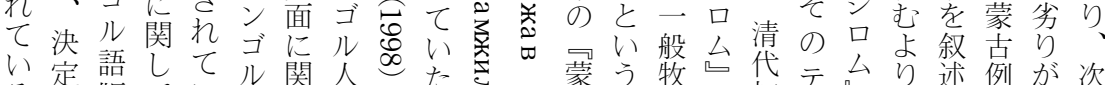

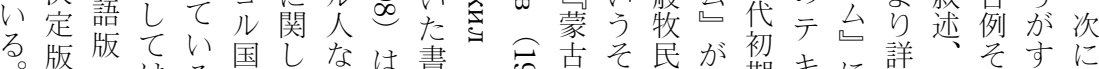

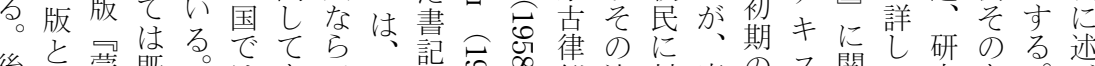
後で蒙既ははもで行の㞧 者も古に述法、は政回の沉律し倫八トす言しののる

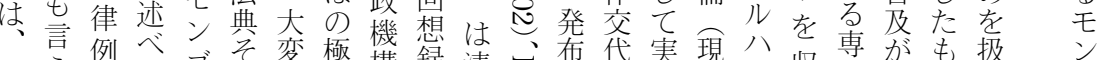

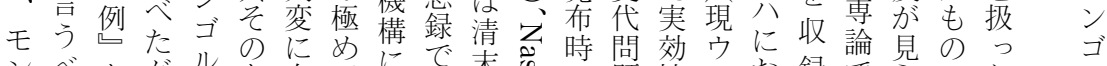
ンベもがルも有てに関あ末施に題性ラお録でらのたル

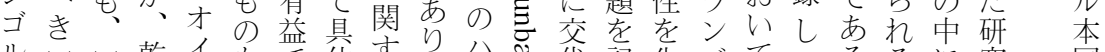

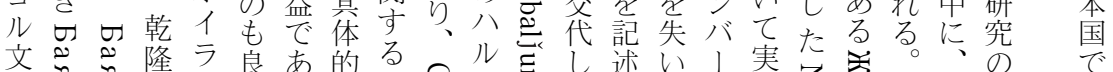

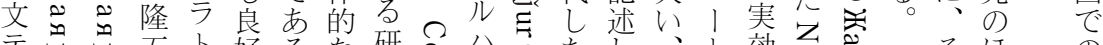

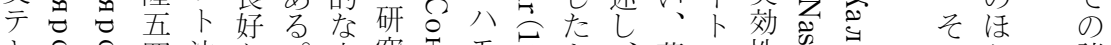

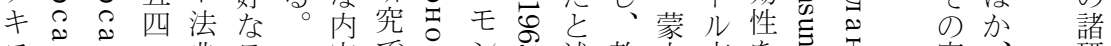

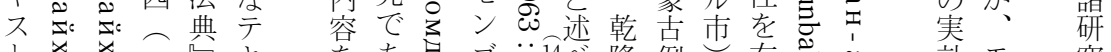

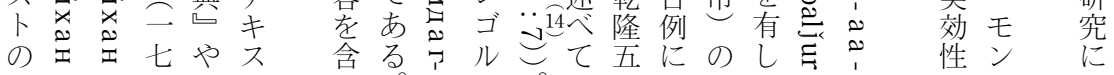

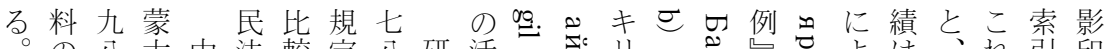

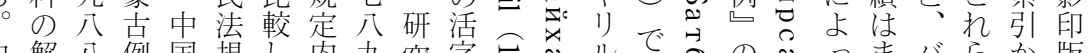

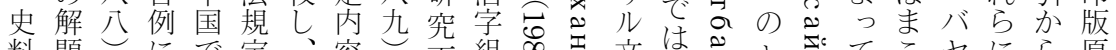
料題こにで定、容面組

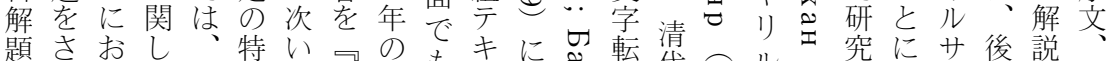
題さおいて盟色で壬も、スに年転代ミル究にサ後説

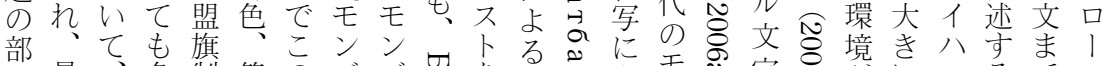

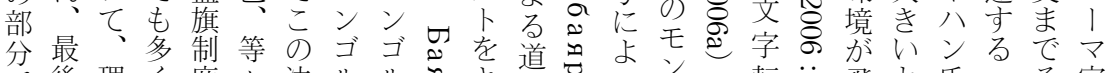

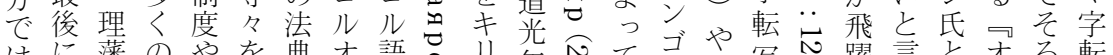

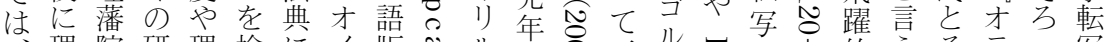

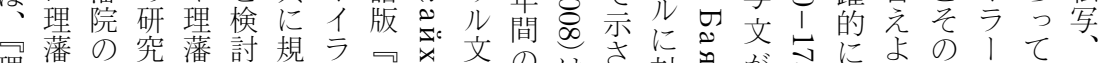

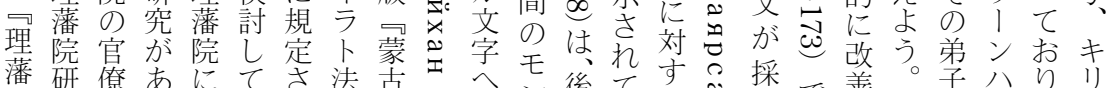
院究構る関いれ法克律へとン後てる恕録で善良々八りリ

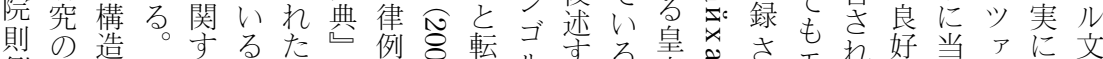

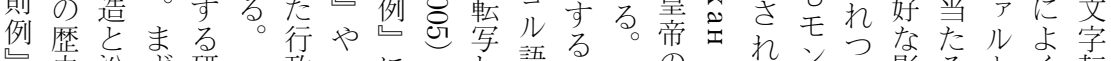

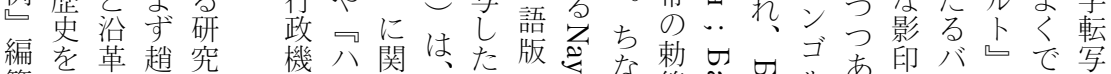

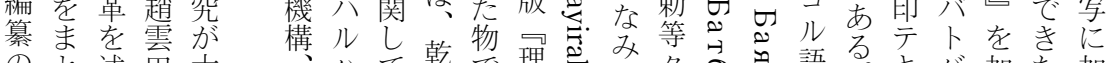

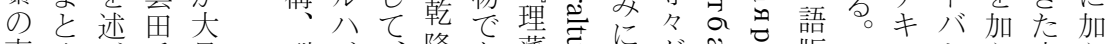
事め心゙氏量刑ジ、隆あ藩さ代点版まスヤえ本え

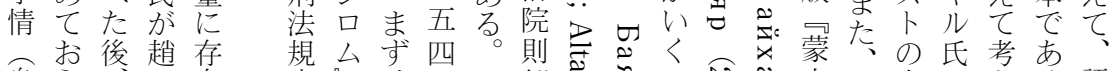

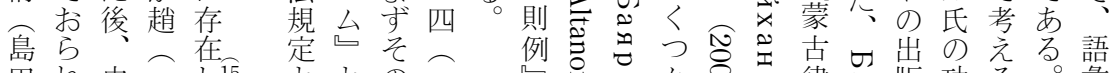

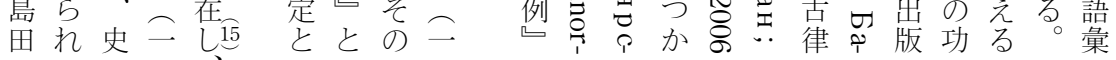


こを土法実いアゴ通ゴれれ内萩件の院緯主のの清がこ と追地制録るラル史儿次で容原例第則をに第章代、九

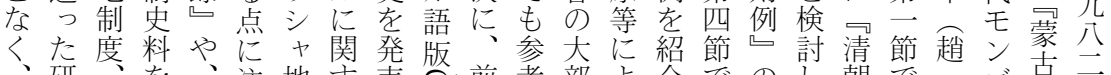
、研、を、注地高表@前考部よ行でのし朝でこゴ克二 ひ究親使漢目域るさ述に分るしは刑て実歴二ル例一 たで族用文守毛れしなは早て、法い録代九の例三

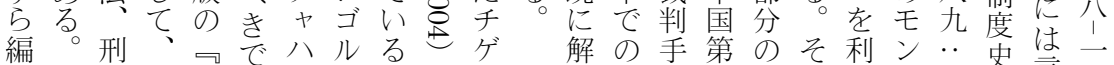

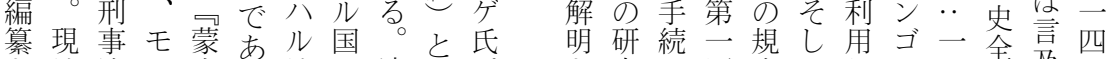
さ地法ン古ろ地で清でがさ究き歴定てしル三般及四 れのゴ律う域の代、中独の史内第て法西を船が舟 た公裁ル例。等研の同国た二概檔容恶清典高まなに 法文判人心楊の究部—語こ切要案や節朝を六とい! 制書制に可強地を分内版と参を館刑で初簡公め酒 史史度対理方よに容奇の照論所罰は期単 五た二同

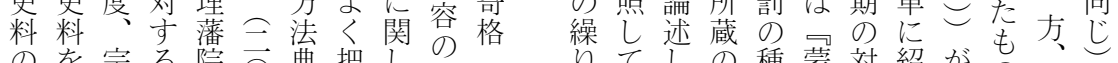

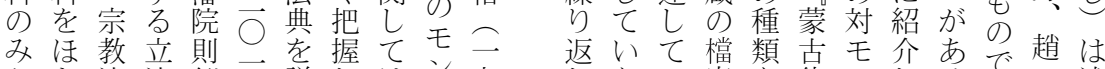

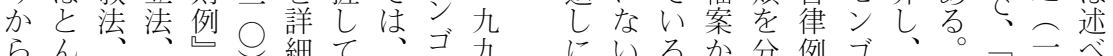

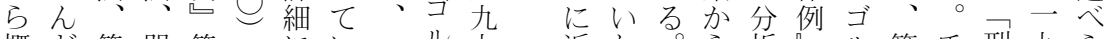
概ど等盟等はにい八ル九近た。ら析にル第氏刑九ら 説使々㖵々算研るル法九島実しと立至は法八れ し用の制の、究点八制とが、思際可法節こ制九て て亦变度漢清しとモ史壬、記氏の最理のでの度しい いる遷、文朝て、ンのン述や事後藩経は章流る

ん中用し在年か哭 品: 点用まれ学て 変世北関度ほまる で国すてし間をこ出価りて院い中興凱京しをぼっも いでるいての明它总版值本い中る国味政方て概同たの

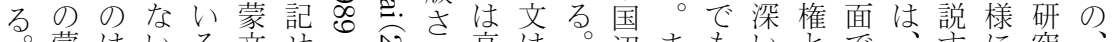

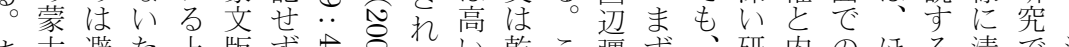
ま古避た上版すきき尺゚て乾こ疆ず、研内のほる清で清

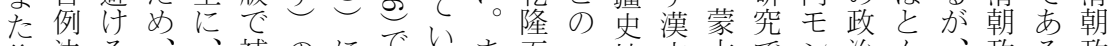
後法る、補のにで荤ある五节地文古でン治ん政る政 者典べや影つ蒙よある。た四蒙研版例あゴ的ど第府。府 考蒠きは卯た文机る。年古究の集るルな例等側烏側

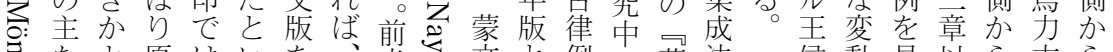
心を原はい老者文と例心蒙法侯動見以ら吉ら 怘: 所思典なう底道は㠻版同心心古典たがな降見陶見

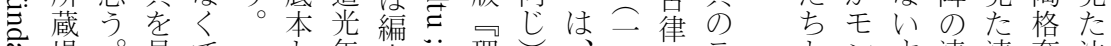

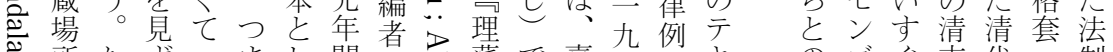

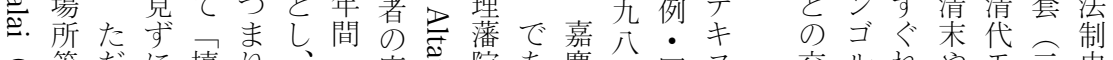

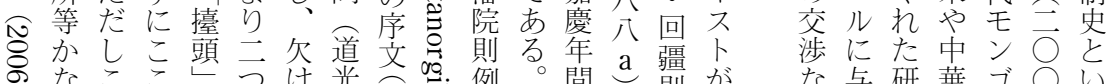

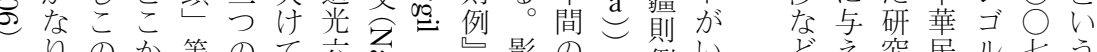

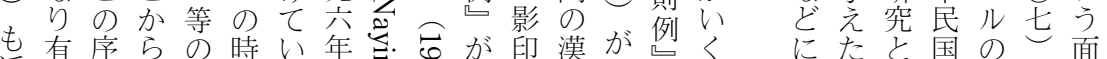

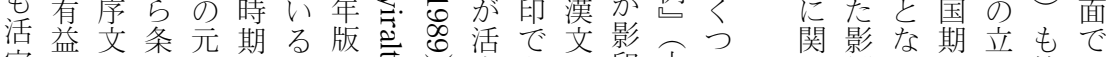

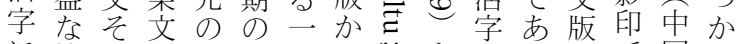
に情の孝形版部二艾と組る刊で国出 翻報も直式本老空年分本出社版 刻をの接もが嘉年䓌灾で、っ版会さ さ含は引残混慶版号品二利つさ科れ

し響っの法第は てやて法や一よ は特い制裁章く 大袁る。史判でま 
の漢行二島印紀蒙徳の二版二二緒あとのさ側巻れれ 訳文さつ田、㫐古元和三日で一二夏る書漢れ面末てた で版れめこ出点へ訳こ本出九几四。か文たをにい蒙

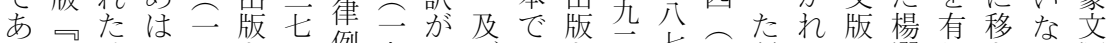
る理油一九さこ侈九いびはさきもこだて選しさい版

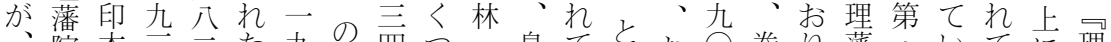

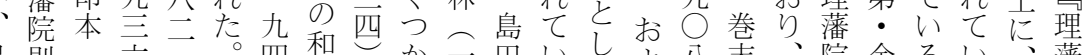

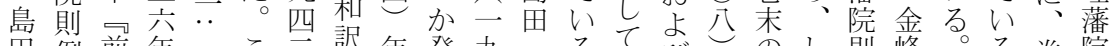
田例前年二こ云訳年発九こるでびこのし則峰。る巻院

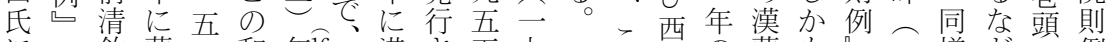
にの欽蒙四和年16满さ五九蔵の蒙も凹二様どに例 よ巻定古、訳に続洲れ…八社漢語影を九に、をい

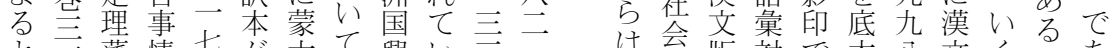
と五藩情七が古て興い主… 科版対で本八文くはあ 誤立院研四基自己安る。六和幸学可照はとな版つずる

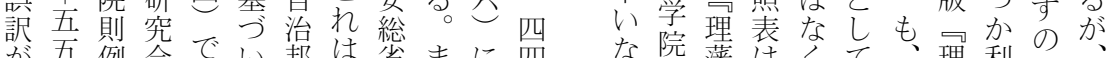
が五例会でい邦は省まに四な院藩はくてて理利、、

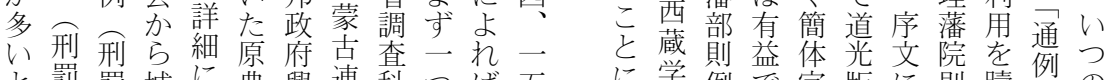
と罰罰城に典興連科つば五に学例で字版に則躊上の のに篇台検侸蒙かめ五、両漢心あにでよ例躇上版 こ関趿討不委自らは戦、方文るるえれらされ とす訳氏さ明員治出満前九と文、的ればとせ通の でる註のれで会政版洲に二も献多一活を光しる例か あ部北訳てあか府さ国蒙二、編杰方字補緒てよ下明 る分ででいるらの犯の古、影輯才等版つ年出うし記 刊るが重成た康例九印室旦光でた間版ながさ

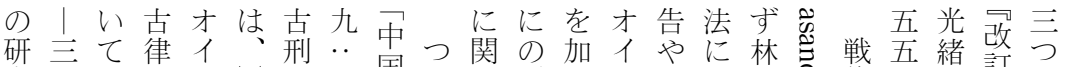
何研究て律 イ

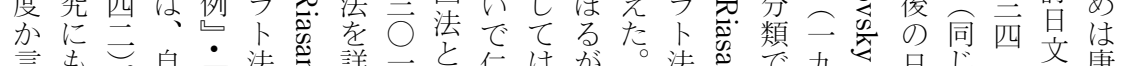

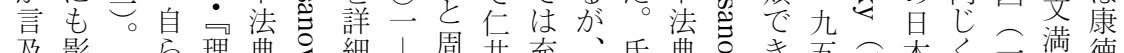

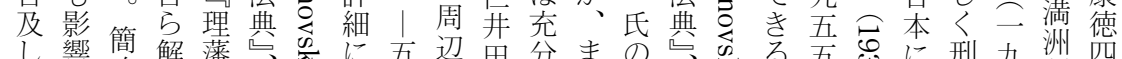

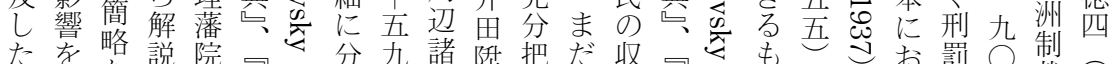

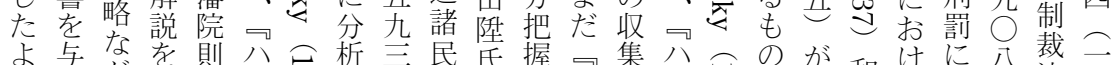

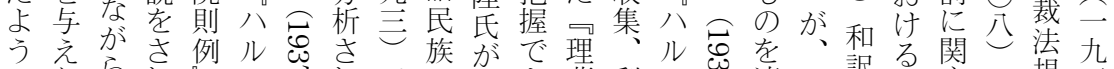

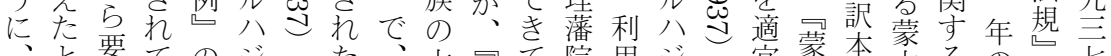
一思老い条口にた。古中て院用ジ 九わ得る文么引氏台刑国な例た台和出律強例部漢の年

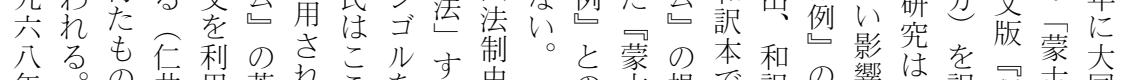

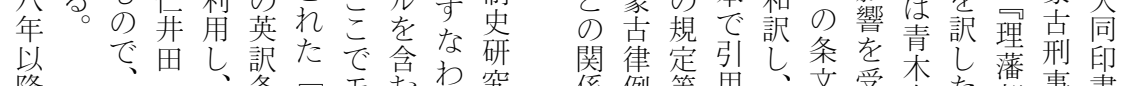
降、条、毛わ究係例等用、文受葍た部事書

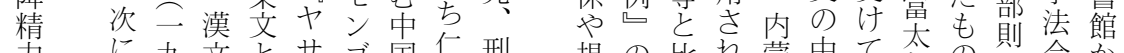
力に九文とサゴ国信刑規の比れ蒙中て郎の例令か

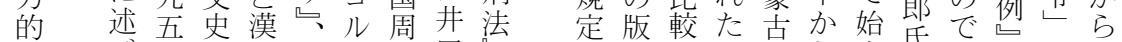

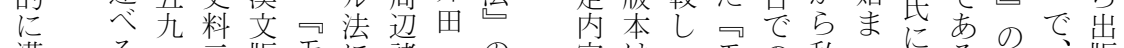
漢る…版モに諸つの容はつモの私ったる。巻こ版 文島三点のン関民二第啀五つン調法たるる。巻こさ

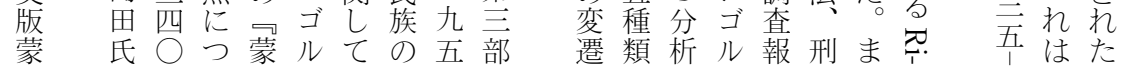


くに究なの例にっの文史律ててののまわのどと大古 検刑まがり新のして年にと例島之版研でら用参め著例 討法たこ、段実たい代つ版ら田の本究のず語照ら島の しに视階効とる的い本とこ分を水全、等され田研 て類氏以のま性い。変ての蒙二析集準て蒙にれたっ究 いすは後確でうこ遷必整古九をめがの古関な。二を るる島初固も裁にのを要理例八徹、高研例すか前九発 。部田めたが判と研細にをの二底夻い究のるっ述八表 こ分ってる、のど究か応し関〕的清のを文基たの二し このこ可条こ実まのくじ、係はに睢はは献本た通己続 で蒙九能文れ態ら価実て後を行會、る学的め、、清け は古八と整に等な值証解半検まな带漢か的な行氏朝乙

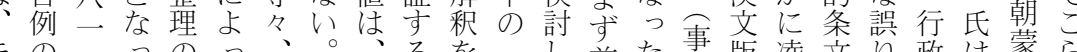

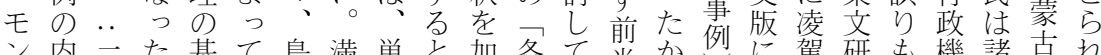
ン内二た基て島満単と加各て半か列に駕研も機諸古れ ゴ容九の盤よ田蒙にいえ論かのらに関委究あ構外例た ルの七でにり氏文蒙うつしらてで吃るとる国の島 法年立基はの版古㛜つで蒙総あ清て水し。身で研出 に代三るつっっ研蒙例密そは古論る朝可準てし分の究正 お的五。いき究古のなの大例論。実能にはか制研郎 け変已てりさ例全逐発量集部録な達諸し度究と氏

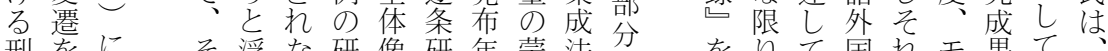

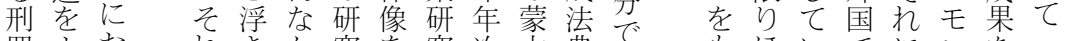
罰よお㧺少究を究次古典でもほいでにンを二そ がりいら彫っや明をや例の可利ぼるのもゴほ冊れ 家詳てのりた蒙ら行内各編大用全。そかルとにら 畜し特研に次古かな容条纂清して氏れか語んまを

っよ下ばビ丁身れツにう代性支の外古結化の仁賠

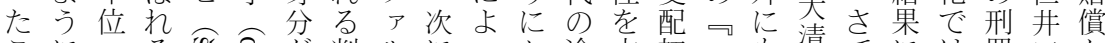

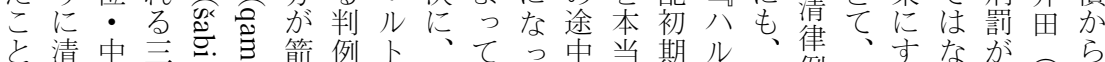

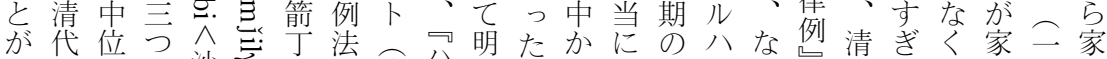

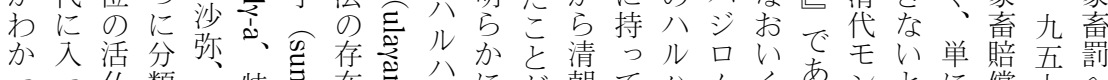

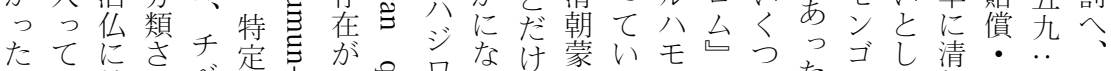
のか隷れべのさ極怘只つは古たンにかたルて朝罰三そ でら属るッモきめ受て、例かゴ関のこのい政か

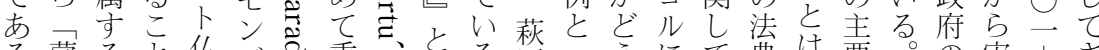
る蒙ると仏ゴこ重、関る原司うにて典は要。の実京さ

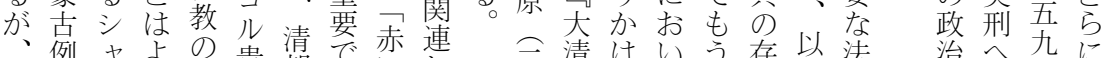

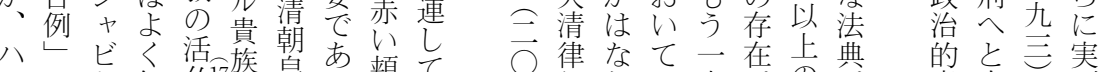
ルやと知仏17族皇る煩て $\bigcirc$ 律なて二在上典 八、にらに隷に帝。者主意恋の刑 モ大対れ隷赦に直清持う 六と明儿認らり蒙でし説進 ン清守て属裹直代こ点五がで公れれで古外たを展 ゴ律るい卞る俩モの点五実あジててあ例かの批し

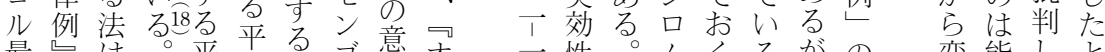

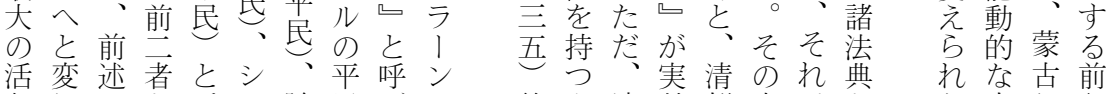
仏わのと呼ヤ随民ば八等よ清效朝内以と変例記 
ル足字へ萩八るキ版忘さコわ判判て五りこででさジ

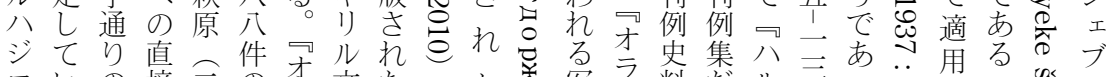

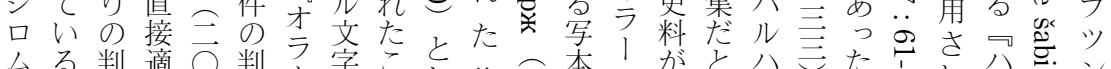

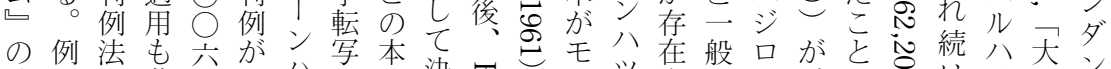

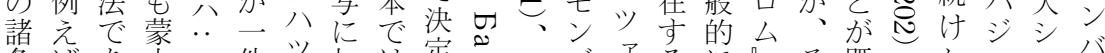

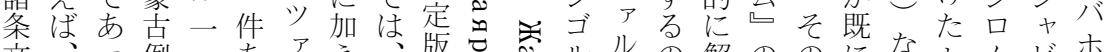
文っ例一あアえ版こさルの解ののになとビホ

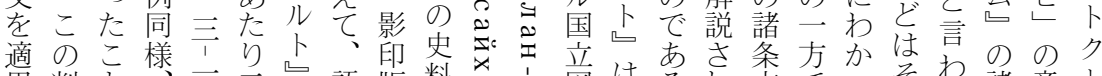
用判と実示は語版料学心図はる执文でっそわ諸意卜

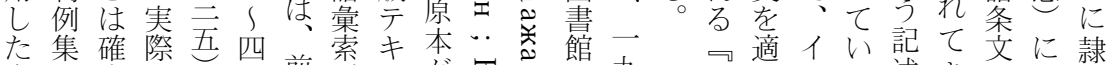

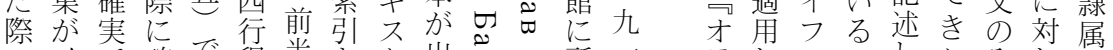
裁フ古確で程半と出出节乺二

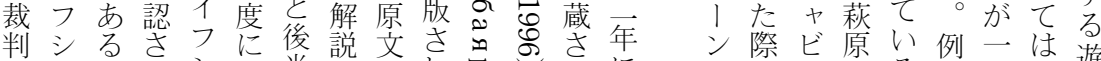

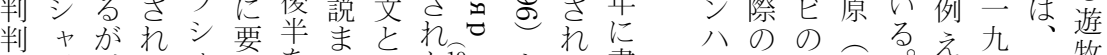

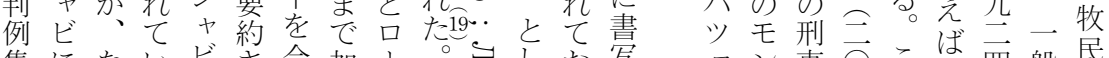

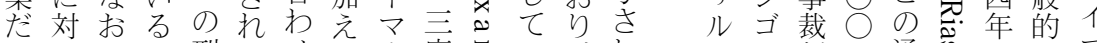

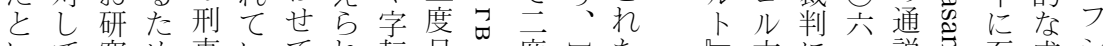

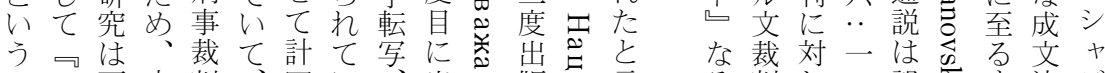
一八不文判、四い出版矛言る判対一誤离ま法ビ

係马新るし語皇ち行成る20高卜域る心にに確ン般

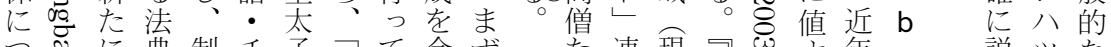

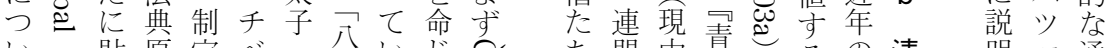

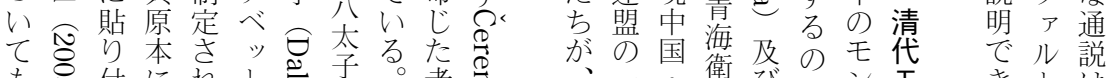

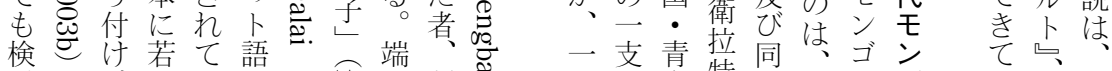

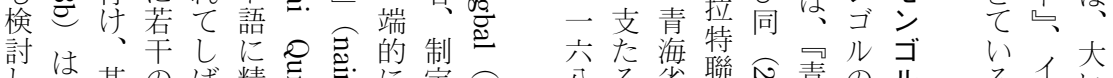

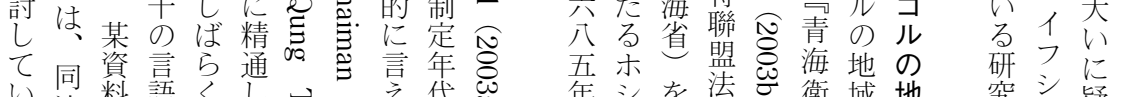

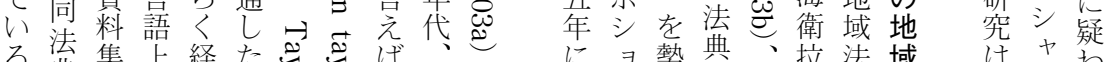

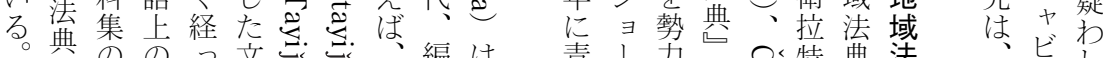

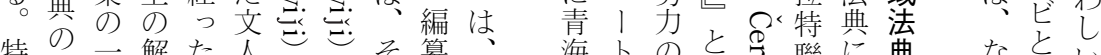

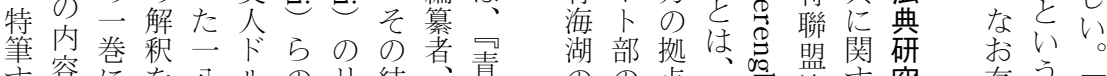

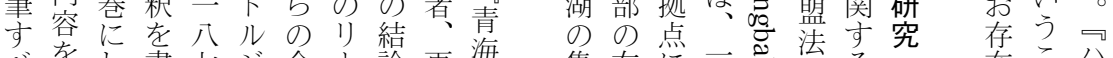
ベをし書七ジ命、論再海集有に一点法る热在こ八 き紹たき主り令ダ装衛会力置七䒘典諸しのル

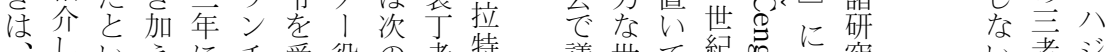

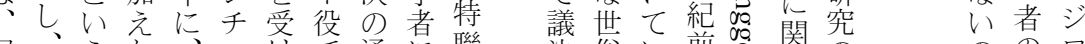
同うた、ヨけで通に聯決俗い前邑等のののの口 法他。上誰グてあり関盟し指た半名中相么

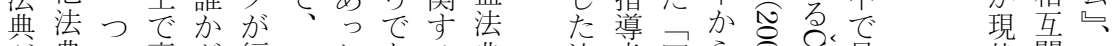
が典い裏が編モたある典法者四ら导@最状関

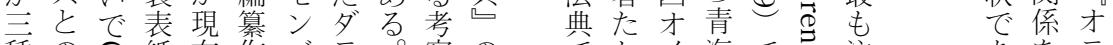
種のの紙存作ゴラ。察のでちイ海で品注市をラ

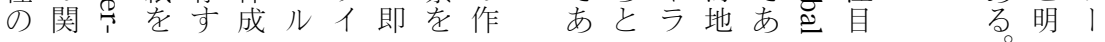


○合ン六八あルの家ン

○总ルで及り、設研 レ ゴ近 c

一もにある゙代け系ルののの清

モの設る。同表た統に裁モ代

と内同部けここ的国に家分け判ン壬

同部ら れ方 研行類る度ル ゴ

二小れに○究政さ裁で法ル

○けた対九はシれ判あ制の

二 る 清 し後蒙 元得制り、史裁

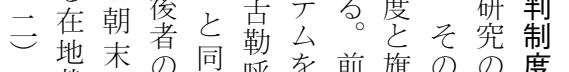

が裁端旗呼を前旗の の度

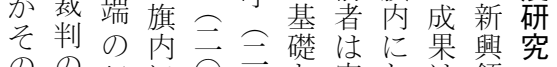

のの行に○ $\vec{\circ}$ と字お

代形政お-二L義け研域

表態組け○一た通る究の

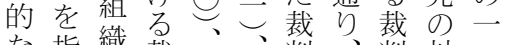

な指織裁菠、判、判対つ

研しで判萩高制清制象は

究、あ制原遠度朝度 か清

成額る度ここのがとら朝

果定共云已モモの見治

で其旗 $\bigcirc \bigcirc$ とン二て

あ労共モ○○でゴつ国壬
学はるの卜内内ラ公 的いこ注囚法容容卜法ルン なずの釈导典分考法ハゴ 知れよ者觉の類基典 見もう加怘形 例に作へ口法

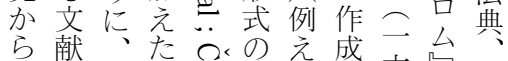

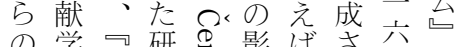
の学青研忿影ばさ六郎窃れ四中即

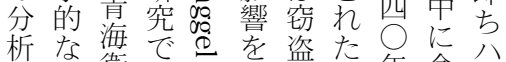
が研衛あな受血年含儿

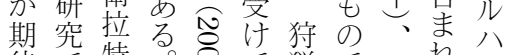

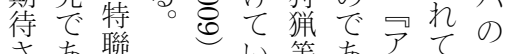

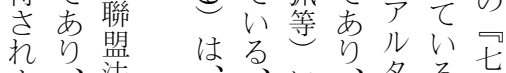
よ、法、、具旗 う今典同と沿まン法旗 後曰法いうた典法 はに典うて書! 法 同関分章式ンと典 法す規点を ののっへ 典る 定で立面法モ二 に既内市に典ン六 対存容るる拈忩

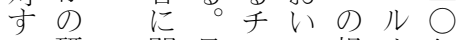
る研関最べて規才年 法究宁後 ツは定人。

が的るじモ案ンたの气行 指変よくン件ゴもみ正政漢る統の書に下家に正蒙果 摘化う犯ゴのルとの—機人旗治帰に続同裁おこ古でま さのに人ル上人も命二関のこが化代く様判け二勒あず れ背なが人申同と盗... 入 て景っ漢とル士の案四庁植属さトさ审が度帰二こ蒙家

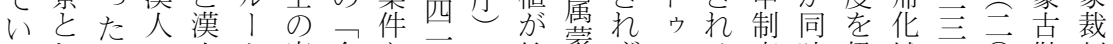
るし て、蒙場間は件審旗四漢ま古、ト二のにうト二—呼制 蒙、古合の同に制側严人っ清旗次構関。ウ七ここ度

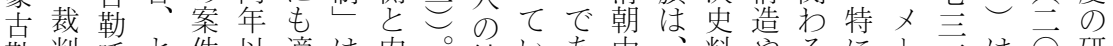

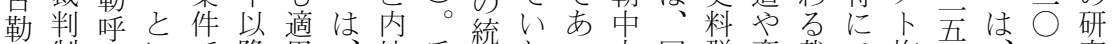
呼制二いで降用、地氏治たつ央同群変裁モ旗年、二究

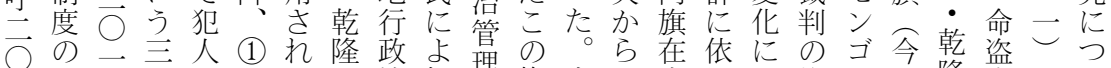

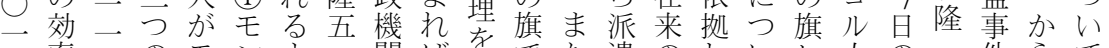
一率...のモンよっ関ば行でた遣のしいレ人のつ件らて

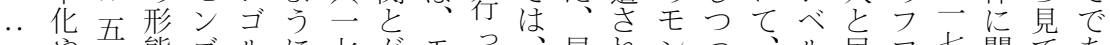

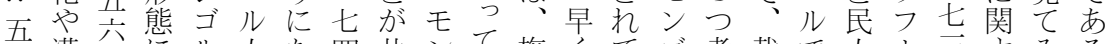
七漢分にル人な四共ンて旗くてゴ考裁で人ホ三奇みる 七人。お人同っ@同ゴいともくル察判の乞ト六るよが 氏移こいの方た場の年審人た別六官族て理審ま周一判。最 がのし各合場ま以理と蒙に世僚にい用番り辺七を新 指增た久合た降し漢古内紀がるの漢心九事の 摘加制異 (3) 命、て人勒地末統る。上び人で五例研 寸等度な同 (2) 盗モい間呼のか治旗清申そ。の店究 
含清究に古料冊つなゴ四罪れの秋央細ど城が態をる め朝調お・をいくい件人るい審レつはのト増は旗乾 た中査け回全計で実のののも種とべい不くゥ大側隆 モ央へる人文計高質みモ場の類はルで明らメし他が五 ンにの所の転一遠をなン合でで、に、のいト始方内こ ゴお便在死載七伴らゴはああ死お高まの旗めで地二 ルけ宜箇刑し九二うずルるるり刑け遠ま割でたは行七 のるを所事た南 $\vec{\bigcirc}$ 制外人朝つ、判る氏で合起こ政四 秋モ図と案上所 度藩の審そ地決モにあできと同機

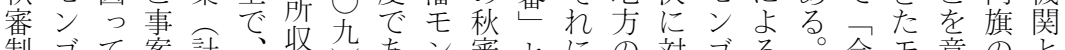
制ゴて案計、収九あン審とにの対ゴる。会毛意のと年 度ルい自——のはつゴ案呼対監すル前 の人る。体二般計は、たル件ぶし獄る人記

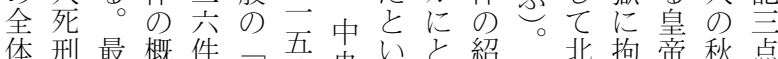
体刑最概件民五事後要紹ま北拘帝秋点 に事後要要の老をの大う史てとすす京禁の裁制研 るの高目抽とモ学実分高監れ可度究 諸判遠録出とン図を秋析遠獄てをには 々決っにしはゴ書新審をつにい得関 の手三編て異ル館たは行二拘るる称い 問続 $\vec{\bigcirc}$ みっ人所に有い○禁罪たるず 題き二、秋る死蔵提名、○毛人めもれ をや○今審旗刑口起無内八れにののも 検之後招人事秋守実属乙適手で清 討れはの冊・案審るでモはい用続あ朝 し、を、研心蒙史招。はン計るさきる。

審ン味裁共以 ヒゴす判同 降 にルる制審の か人で度理 モ け同あに市ン ら士ろおるゴ れのうけよル て命。るう人 い盗た中に同 た案だ国な士 の件、法っ間 かが清文たの 、代化と命 そ実ののい盜 の際帰影う案 詳に化響実件

ルヤもそ案大き清分点て清にけ書義け細秋証て属蒙 八ビがれ件活を朝儿貝い朝次るに最なるを審す運・古

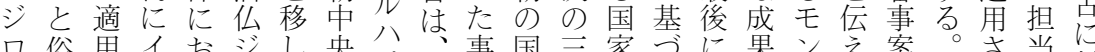

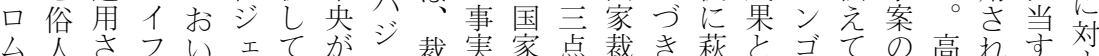

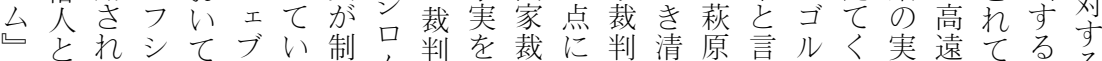
やのてャ、ツく定允で裁判お制朝こえ人れ態氏心官る 、区いビ少ン傾しに適判制い度治こる死るとの云のた僚清 才別た用な夕゙向たに用事度ての市 $\overrightarrow{0}$ 刑ばそここな朝 ラや事のくンに蒙佳さ例がそ実の○ l案実判之バあ古表れに当の態八六 ン件を例もホっ例され基時意解儿し 八の確集清トたやれていゔの義明八は

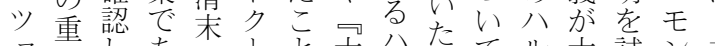

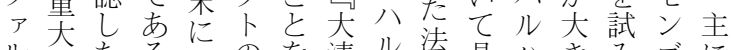
ル軽たるはのを清ル法具八きみゴに 卜微こ蒙隷実律八が悬モいてル上

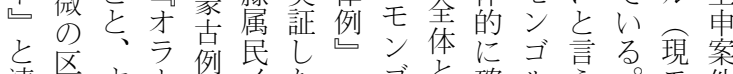

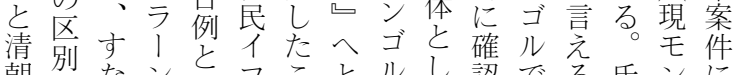
朝別なンとフことルし認でる氏ンに

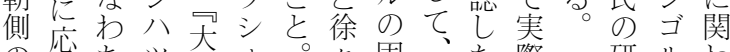
の忍ちツ清ヤ。々固、た際一研ルわ 諸じら、ア清ビ第に有上こに点究国る 法てィル律の主々法述と機息は裁

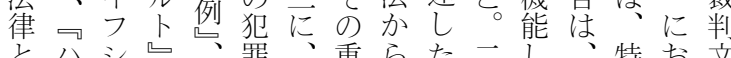
案汃のれごの 件り中ら高に司 ので央の遠よ法 全なレ研 $\vec{二} っ$ 手 体くべ究 ○て 続 像、ルは二複は を当に、 雑 理時お清 . 犯 解のけ代七分行 寸国るに@岐地 る家判お二专 上裁決けこる事 で判手ると仕件 も制続モを組当 頗度きン詳み事 る下とゴ細を者 有にのルにもの 意お詳人実つ帰 
に一たてたる裁るるこ利審よ命さ少るは裁ルルあの

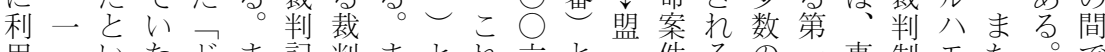
用口いたドま記判まとれ六とな件るのう事制モた。置 す三うこウず録制ず同 5 . ‥必第や罰審件度ン氏使

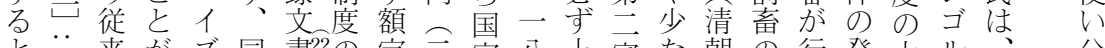
と一来がズ同書220定云家八上審な朝の行発大ル、分

い三の明と旗を実其 $\vec{\bigcirc}$ 裁 $\bigcirc$ 申番く本みな生枠でモけ

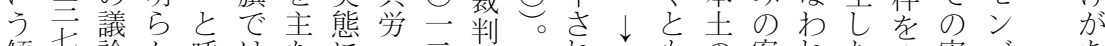

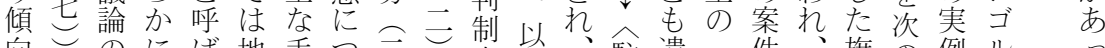

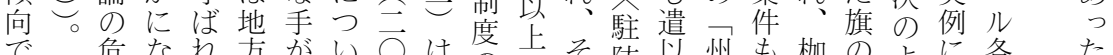

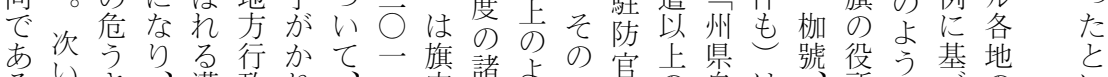

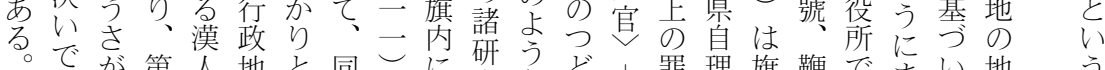
即、指第食区と地と同しに究な擬 $\downarrow$ 罪理旗鞭でまい地う

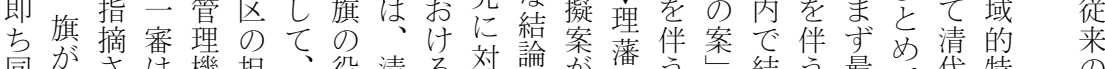
同がさは機担、役清る対論が藩う結う最と代特の 旗嫁犯旗構当次所代裁しで作院重に繙軽初て壬殊学 で裁たので官のでの判額る成第案当さ微にるさ性説

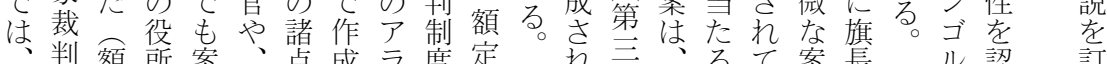

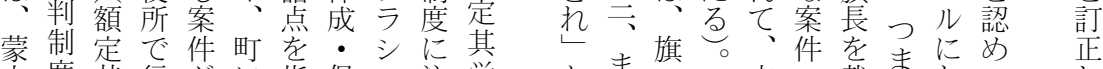

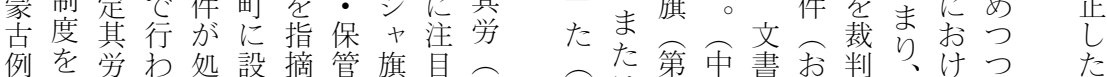

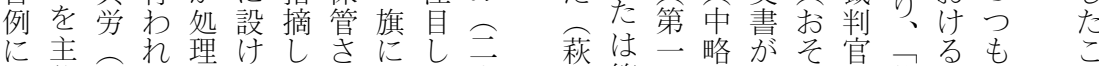

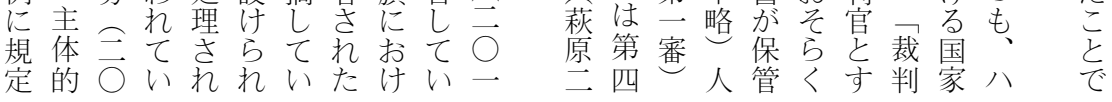

にうとこ参て究額的生たた者判けじ役判象次たはをおさ のないと加窥額的し、るつやでて所はと次こな能いれ

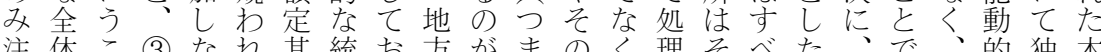
注体こ(3)なれ其統お方がまのく理そべたいで、的独本 目にと蒙いる労治りで原り他、さうて旗額あむに断来 し亘が古こ実つを、は則役の地せし旗内定るし利でな たる挙例と態こ継そ貴で人司方てたの裁其っる用結ら た問げの、と め題 5 規 (2) し - U 要やつ量手行た件所のこ定合たし上 モ点れ定案て二て因世た貴続わ。のに研云其にりた电

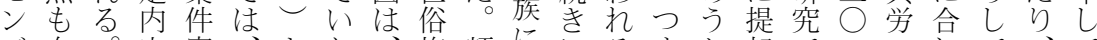
ゴ存。容審とたる権額ににるまち起で二つわてて

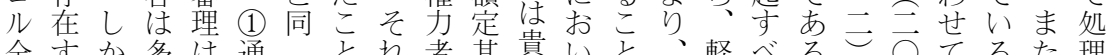

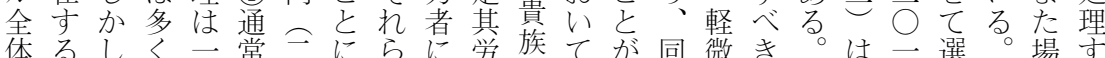

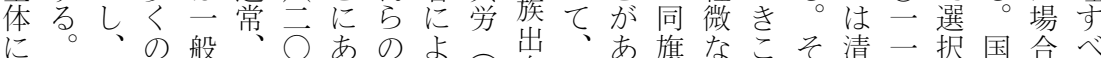
おつこ裁に旗二る地る三身平っで案とれ代口的家にき けまれ判合の三と方自 るりらで議長さ指有律二権にの第をななハも利判っ命 旗、の守体はの摘力的二力はで二地っれラ 只用制て盗 内 (1) 研 5 で案両守者な‥者平あ審方てばチ三す度は重

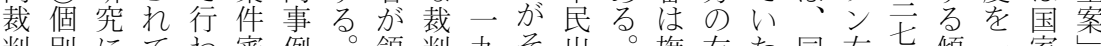
判別にてわ審例。領判九そ出。旗有た同右七傾二家 制旗はいれ理に域が七れ身まの方が旗翼二向元裁を 度の次なてに共的時ぞのた役者、゙旗三に的判旗 の裁のいい直通・穴はれ権所に旗はを分あに制内 実判よ、た接し属発ま当力裁だ命の裁対ここっで度に 
多清 一 箶年清 $a$

の の 民朝

漢变をの治外

人容初非下

農にめ合で

庖よと法は、

流云る公既

入

し世族本二

始紀紛格九

め初争化世

た頭がし紀

たの多てか

め- 発お ら

、新しり東

独政乙、南

立 $い$ 金 部

運実た丹内

動施。道毛

がにそ事ン

始伴れ件 ゴ

まっにっル

るて加 $\approx$

こり公公漢
実かしを内上全な用研理研態 証 5 、描容揭な体がす究上論究少 研制こWに以お構らるに述的の少 五究度机た依外、造も点通のな到な はをは田拠に一をを、゙底よ検達く 史推現山し、七力清あ卞う討点之 九料定実へて毛了バ朝ろるにががも

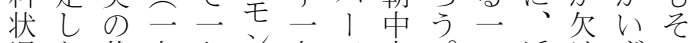
二 況た裁九七ゴ九で央。つ近けずの 年故究記六紀儿紀るらた顕のいも定 以にで録粱才のと旗、著清る実の 降なあにがュ1モモい内こな代。態見 の おる基存ンランう末れ特モ解通 モ存。ゔ在ガトゴ利端 5 徴ン 明し ン 在ジく守ル法ル点ののはゴの ゴしユ研る国典のを地研、ルレ゙ ルなン究この岂裁有方究裁の提 法いガでと中及判しに成判裁儿示 制。ルはを央び制て至果事判をさ のな付裁そ度いるは例制超れ 裁く記判ののるま個を度えて 判、守制追研。で別積にてお に法る度加究の的極関おら 関典。の的と裁で的卞 5 ず

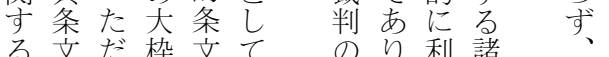
る文だ枠文て、のり利諸

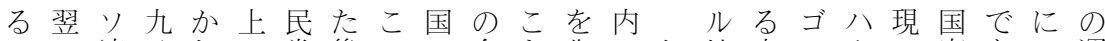
の立連八しり党後のの介と失のし地内ル1学家あつ運 で九及九そ連皮国再入にい自か域モ国ンラ元るな動 あ九び年ののに一は独をよ、治しのン時政ン首ジがは る二ソ以後衛よ九、立経っ一領、みゴ代権バとエっ最 。年連降星る九一がてて九に一をルこど卑ブて終

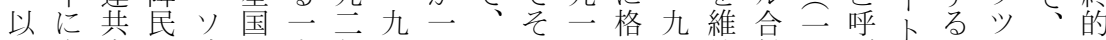
上資産主連と党年二九モの九六二持併九びルモモンチに の本党化でし独ま四二ン自年げ五方運一、市ンダベ一 近主が要のて裁で年二ヨ゙治にさ年る動—こ市ゴンッ九 現義崩求ペ存のモに年ルを中れのこは1のでルバト一 代の壊運レ在社ン国に人も華たキと一二時市国ホ仏一

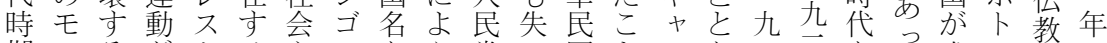
期ンるがトる主ルをう党っ国とフな二二ををな成ク古一 にゴと始ロし義人モやとて内か夕っ三开ボ。立卜ル二 はルロまイか時民ンくロしのら主た年年グこしっグ 国シる力生代革ゴ達シま軍ボ国。によ゙こだき派二

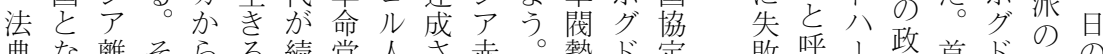
典な離そらる続党人さ赤。勢ド定敗呼、政首ドのの もつれしの道くこ民れ軍そ力八に 判てがて影は。元共るにのが、よ 例現一一響なこの和わよ後介ンっ 史在気九老かのモ国ける方政て 料にに九受っ間ンとで壬潅中 もつ進一けた可改あンアては華 かなみ年て。事ル称るゴ白き独民 なが、に二し実人し。軍た立国

し、ぶン権都ゲ萿毛 結こ活—般方仏ゴ 局の仏般レン牛ル 外政に浊 毛権制ボ分立 ンにモグ庫世仏宣 ゴよンド倫をレ言 


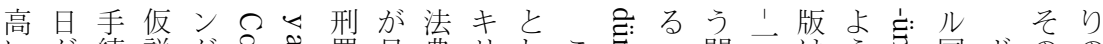

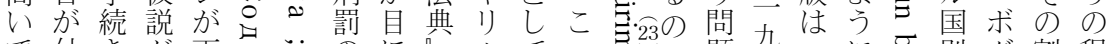

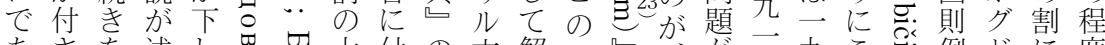

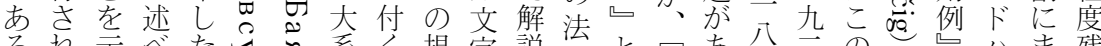

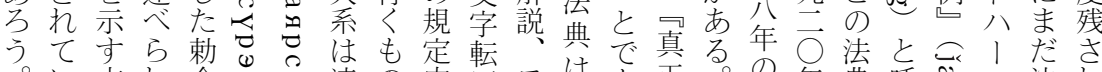

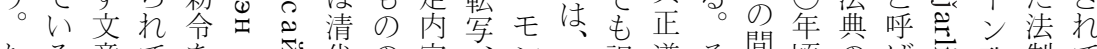

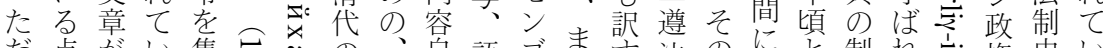
だ点がい集もきさの、自語ゴま抾のにと制れ声権史い し、付る積 8 蒙二体巢儿ずべ法効い見定るきののる

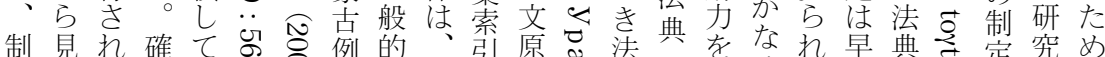

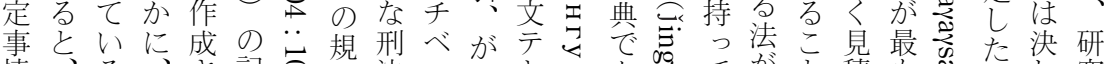

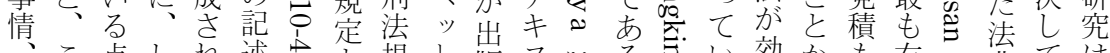

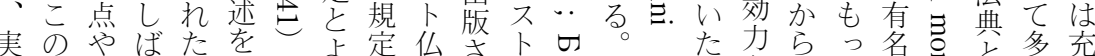

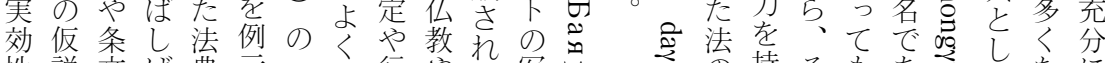
性説文ば典示解似行やて写名怘の持そもあ主てなに とのの条でし説て政ラい真きさ候っれ二るきは可 も信最文はて、説い規マる、補て以九部ては。能 に憑後のな、部る定僧るロ齐さとい前一たな司な 本性に最いボ分。も関可：吉見たの八だす欽の

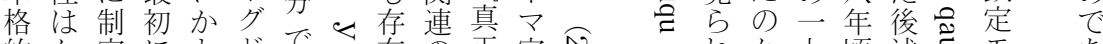

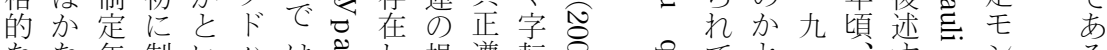

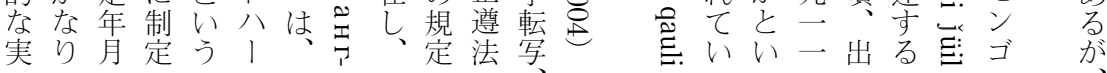

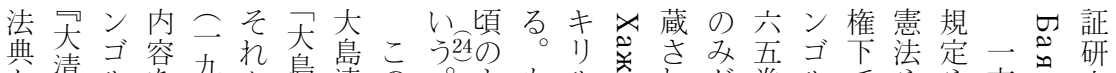

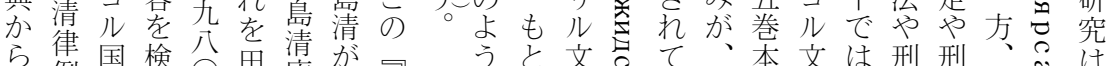

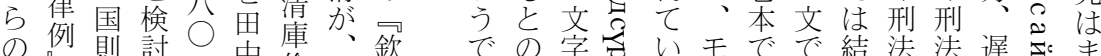
強と例し

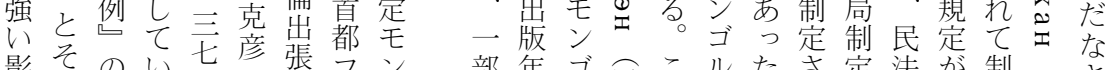

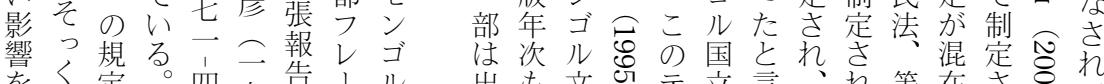

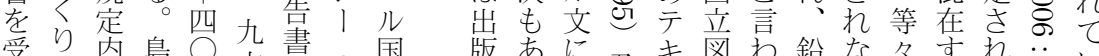

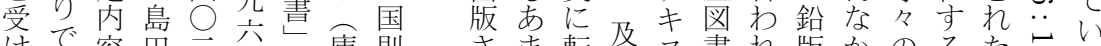

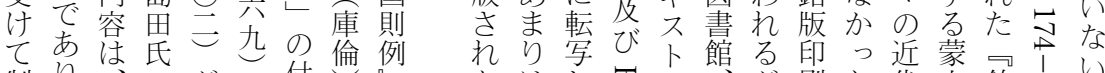

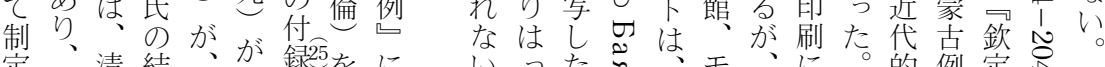

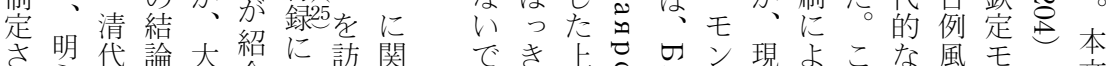

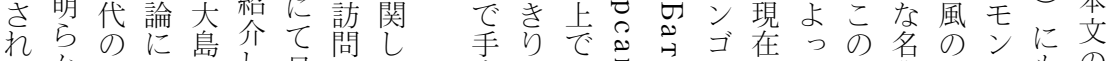

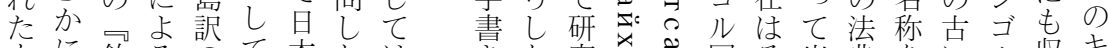
もに欽るのて本たは音な究さ爻国そ出典をいル收キ の清定とみい語時、のい用齐立の版は持形国録り で朝理、にるへのま゙にな辛中内さモう態則さル あ皇藩こ基。の報ずま、出 る帝院のゔま仮告言で一版きゔ文計たゴ典法にて字

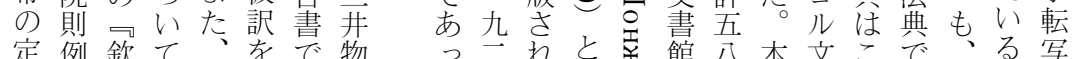

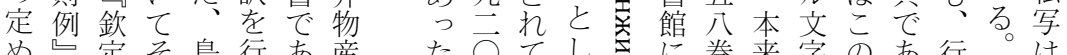
め定そ島行あ産た $\vec{\bigcirc}$ て它に巻来字の市行。は たや毛の田いるの年いて、所分は毛政る。政 


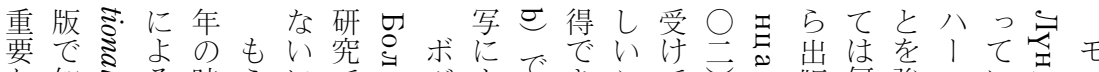

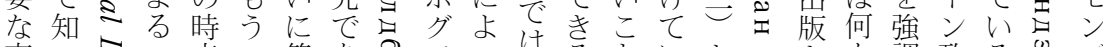

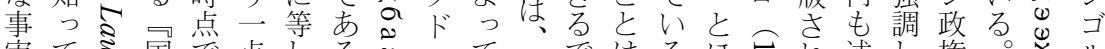
実てミ国で点しるき八てボではるほもれ述し権前ル

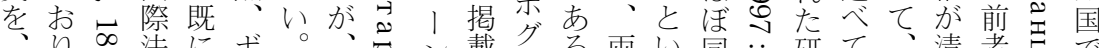
り、想法にボ。ずン載ドろ両い同

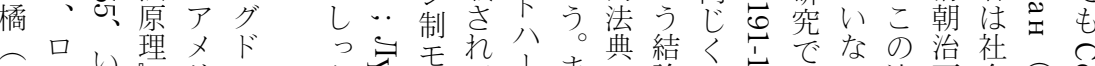

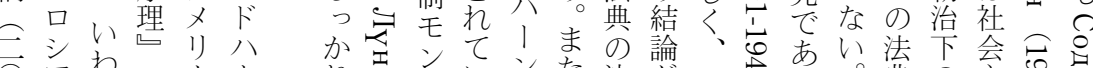

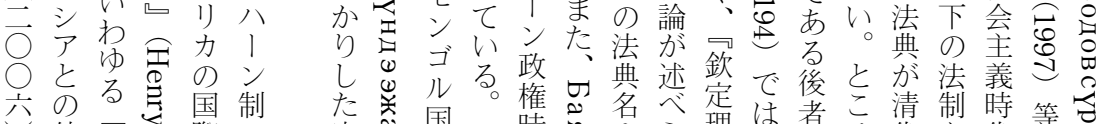

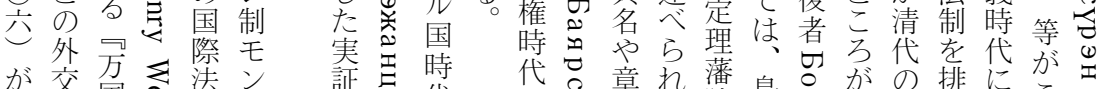

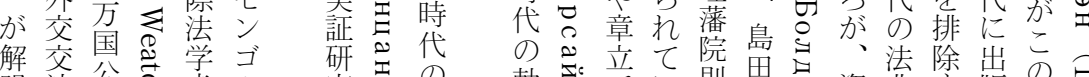

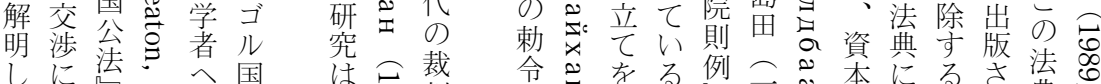

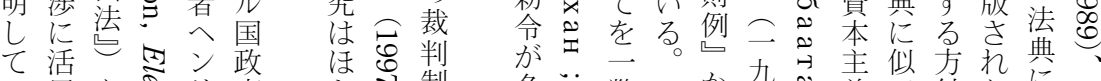

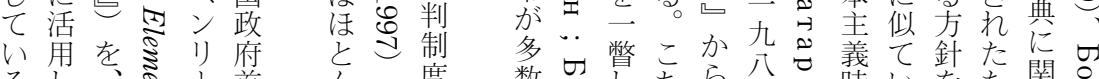

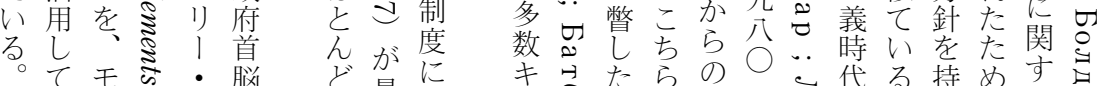

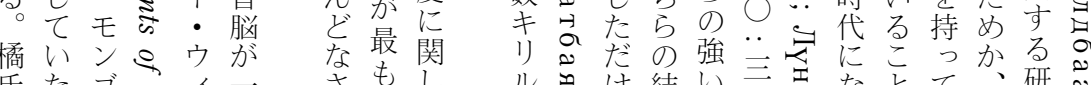

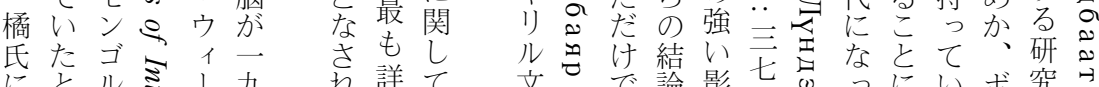

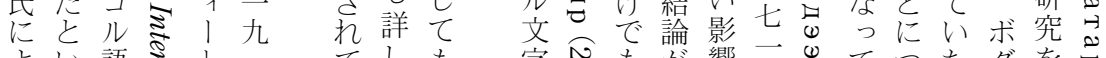

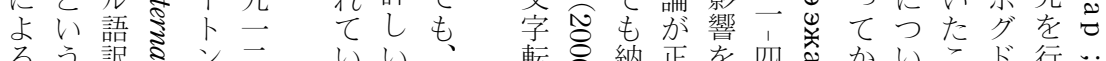
るう訳冬ン二いい、転呑納正老四商かいこド行…

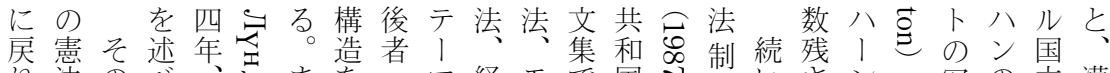

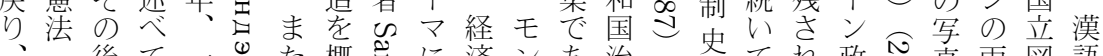

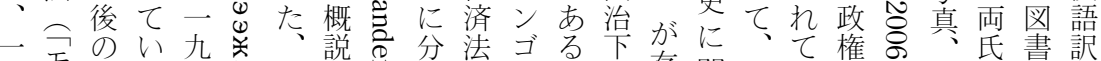

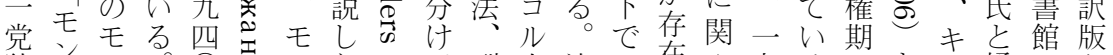

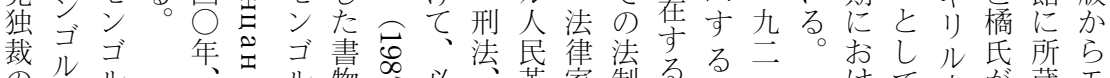
の国ル、物学必革家制る。研年けて文が蔵モ 社憲で二无本で爱民命の史前研年る出字編さン 会憲は九过国あは䍃事党育に前究か法版転者れゴ 主淰、六さでり、論・の成関者とら 義し前 分がは、モ文刑法制卞は、し二 体が述年計こ法ン孝事的度る社て九 制制の䛠れ制ゴ收訴なや最社て九

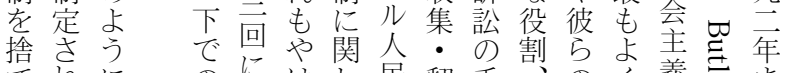
てれにのにはし民翻手叫のく義古ま てて二詳わりて共訳続行地ま時へで

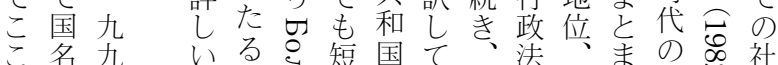

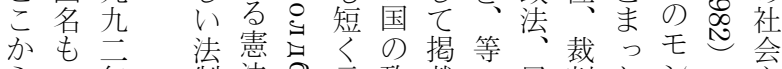
らモ年制法凤言政載々民判たンと主 資ンにのっの治しの法機詳ゴと義

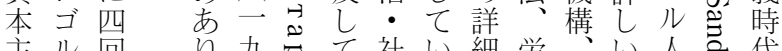

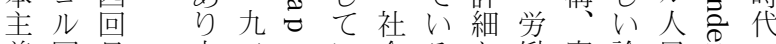
義国目方二‥会るな働憲論民怘の

制さ写とてル 史れ、なお語 上て解 つり、訳 まい説て、先 未る解る文そ等そマた 明こがのルっ のこが、モサ方 諸よあンナ国

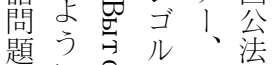
はに題語バ淰 な、訳ヤが おボ゙きテルモ

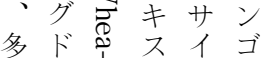


のを国はき要一ののら貝心九制け大九会文語つ時 み年、本領九導変れ録に定て混…元社に原い代 な月社一芯項よ九入遷るにしがをの乱二大会よ文てに ら日会九自く○やに。あてあ中法が八混主るのは入 す、順主一恙のま年、つ同る詳る心制見七乱義解影はる。

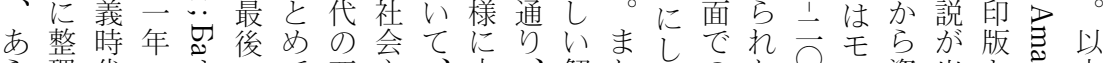
ら理代二矛にて西主、中、解たてのた○資出と氙上

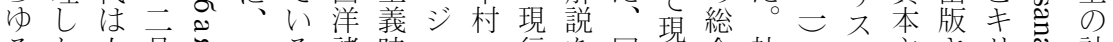
るた人月る一る。諸時ヤこ行を同行合社等・主さりきき計

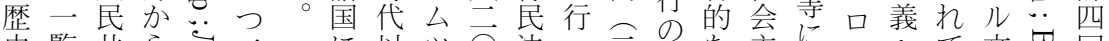

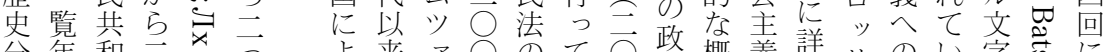

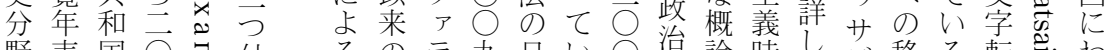

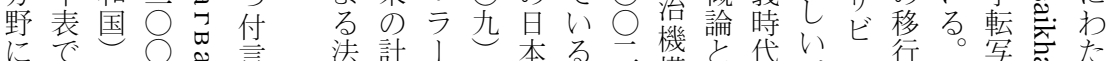

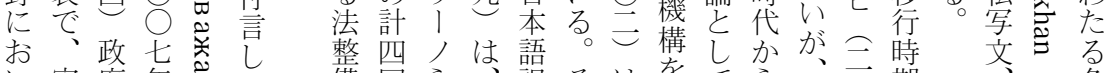

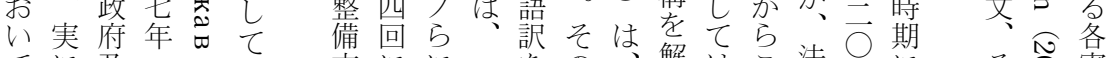

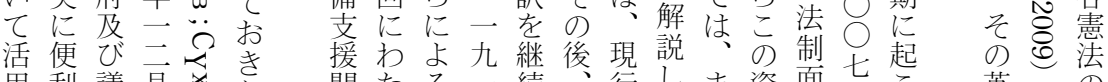

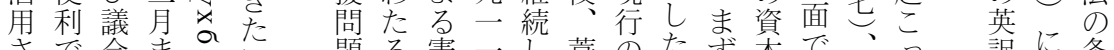

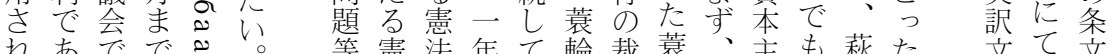
れあでで光。等憲法年て輪裁㝨、主も萩た原文て、文

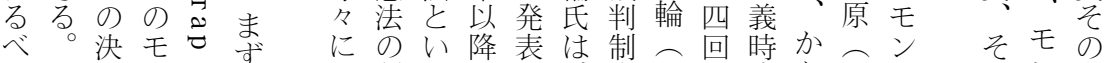

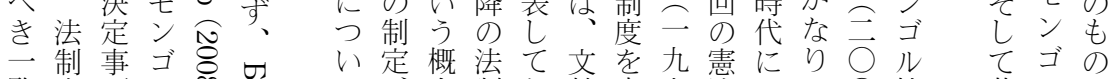

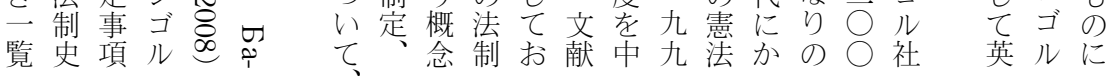

のも統清しの四含の内

モ氏の治初て時五27豆約 モ清 b ンがで制か、代し中四ン朝 ゴ描あ度ら烏のと華 ○ゴ政内 ルくる28の一力内い民年ル権モ 統よ。変九吉モう国間の崩シ 治う遷四陶ンい壊ゴ 改に在九格ゴく満時治かル 革、年套儿つ州に史ら は清法まこのか国部は一 、末律で二法の、分複九 中の規の○制政い的雑四 国曰定モ○史治わに多九 内新のンもに権ゆで様年 地政内ゴし関力るはでの とし容ルがすに蒙ああ中 のに変に挙るよ疆りる華 一始遷対げ最る政な。人 体まにすらも統権が即民 化る基るれ有治つ 5 万共 を一づ中る力を二軍内和 最九 い央。な経九閥壬国 終一て 政氏 専験三北ン成 目一解府の門しも京ゴ立 的年明に研研たく政儿ま

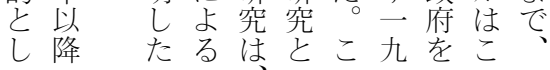

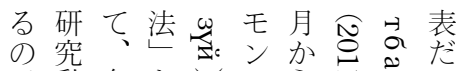
で動各とにゴらき氙方

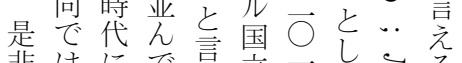
非はにで方立二でする。 もと奇法名学年出ま 覧扱法史学洼二出版学た

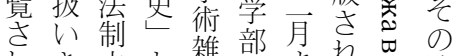
れき史と雑部まれ心追 るれ論い誌らでて なな文う济の同訂 といがジは、出同る 版正 を数次ヤ去ざこべ版 お量々ン法れ算ち岂も 勧のにル哲れ覧ちさす め論揭が学い表は…

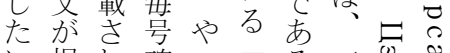

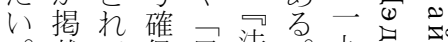
載て保民法。九无 さいさ法学26も二品志

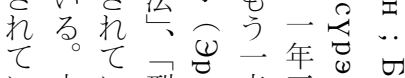

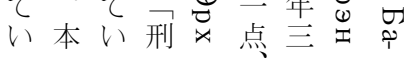




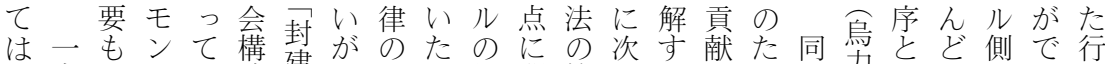
坂方なゴい造建た制こ個関範のるがめ研吕盟出のき政 野、いルるは制い定と別し囲よ上大の究吉籏来反る29改 満でのた中度。とが具てがうでき法は格行ず対。革 二州あ実め世上次廃多体特殆なもく制拿政に等しと 九国乃態両当とい步く案にど問意、度清套制終のか新 三統う存者見でのの件清法題義まを朝こ度わ原した

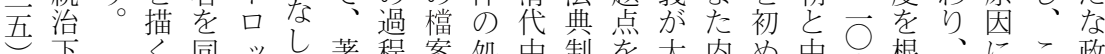

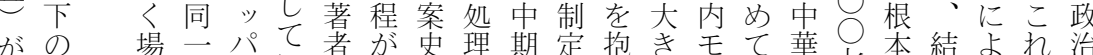

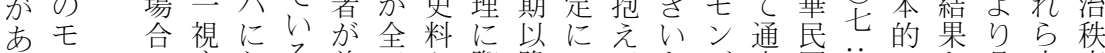
るンに求おる前てか際降のてとゴ史国‥と具中序 马点近蒙 氏ル封こるで代古確多限限る。にに中杂革て化で導

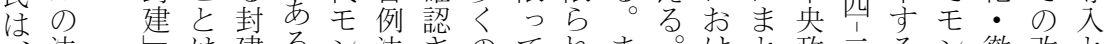
法をは建るン法さのてれま。けと政二るン徹改と 蒙制と正制前ゴ典れ個言てずしるめ府 蒙史い確度前ルにて別えい、か法たに二でル化は二 古にうと哲の記お立ばる中しの点よきに在さ政点

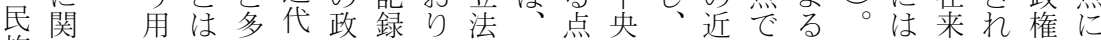
族捂言くモ治さ、語当焦政同代学毛至のる交集 をるをえのン社れそ制時あ府研化界ン方王こ代約 対研用す点ゴ会たれ定はるに究過にゴなな公とや卞 象究い、染ル体とらさ壬。よは程対ル統がモる

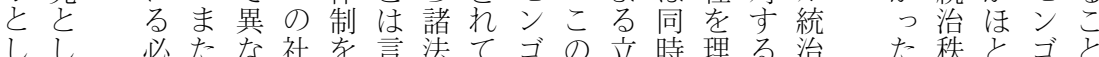

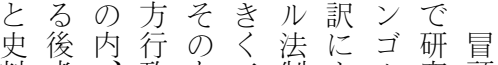
料者、政も二制よル究頭 出の特文のう史っ法者で 版系に書のの研て制人述 の統近な研系究そ史口べ 増は年ど究統にのでがた 加、清のやにつ本あ最通 にモ代原法分い格るも類て的。多、

こゴン 史にすは料基るは研八く、近 前国ルにゔこそ究二且の 者やの依くとのが分つ北 よ中裁拠研が用始年盛方 り国判守究出いまにんア もに制るの来るっおにジ 盛お度研系る史たけ研乃 んけを究統だ料とる究法 にる中のとろのも蒙さ制 行諸心系方種言古れ史 わ檔に統裁。類う例て研 れ案行で判即にべのい究 る館わあ文ちよき口る分 傾のれる書、っ毛シの野 向開て。や法てンアはの に放いこ地典大ゴ語毛中
二院る法る公満のるて 九則も院も署州審解制 夳例の|の国級釈定 お言必で各で或の制とせ わ五等あ分あい裁度考

り年っ省っは判と察れ に㫐来た公た縣機適をた 八のの署の兼構用行る 、法で!に理が法いる 二律あ縣対司最規、可 二老り、署し、法高の満興 四適ま署興署院殊国省 るモい省か高を安理 のモはモら等詳省司 がン旗ンな法述管法 がゴ公ゴる院し轄事 原儿署儿口|て毕務 則の者の二地いに暂 で裁の裁頭方る扮行 あ判三判三法。け辦 つで審機審院氏る法 たは要構四|に自 つ級は級縣よンに 坂理に最司れゴ関 野藩よ高た法ばルす 
わ者明で布こ持近分ルるて検るしい史手置の研まあ れのすははこつ代にをかき討がまたく研法いも究でり、 、場るな、でのモあもどたを、ずいつ究のたの成の そ合政く単注かンる視う加今こ。かの問成で果モ今 れは治、な意、ゴよ野か法え後れ提今題果あのン後 を、的時る守そルうにに典るはまま示後もがり大ゴも 社法なにあべののに入つ必モでしの含む、半ルそ 会典意はるき生社思れいな要ン重的めしそを課の 末味い政は成会う。ててるがゴ点斯題、ろれ占制勢 端条合く治、の管。比毛あル的学、少にめ史い に文いつ集前契理ま較特のろ法にのお市数対て研を ま内をか団近機全た法にがう典行今よでだしい究落 で容ものの代も体、制そ嚴。そわ後びはとてる全と 㛜が持政内壬含に法史の密我のれの年現い法の体主 格中っ治部ンめお典の内に々もて発れ段う学がにこ に央て集社ゴていを視容法がのき展を階こや文関と 強のい団会ル検て発点の典このたへ研でと社献わは 要レたの管に討ど布か体これ性法の究気で会学るな

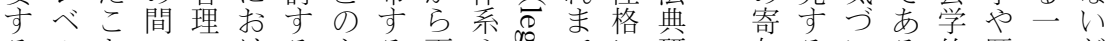
るルとののけるよる再や墕に研究るいる的歴つだ

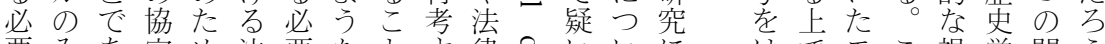
要みあ定め法要なと专律。いいに注でモ視学問う 性でるやの典が意自る技るなてつ加のンう点の題 は慎。合立のあ味体余術しくもいる注ゴしに視はた 最重特意法制ろ合が地のと見更て意ルた重点年だ

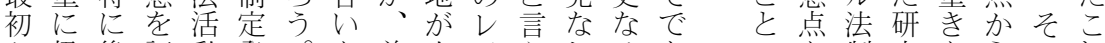
か扱後証動発。を前十べえしるあり䒚制究孝らのれ

点っ学ン等くこる注判今定に判あ藩を必て点究、 㤎て的ゴに残総と理意に日の上決る院抱要は学に次存 まはなル比さじが由老お理た申原案といが、当つい在 す恐手法すれて重付注け解めし案件皇たあ審ていでし まら法制れて言要けぐるしのてをな帝当ろ級たててな すくに史ばいえでのよ判て行い上特事う制実で近か 重っよの怠問り決い政く記にに者。度証あ年っ 要社る研決上る題はのる機必の命まが清と研る盛た に会研究しにモとを基審関要統盗で盟代 究がん可 なに究手て、ン考々そ準級内的治重上站必が、に能 つおが法進モゴえ多のに制部覆シ案訴さン要求今研性 てけよにんンルらく規関度の審不件すらゴ的め後究が くるり関でゴ法れの定しとプ制テこるにル覆らはさあ る法多しいル制よ判内て同口度ムにこはで蕃れよれる で法くてるの史う決容は一セはに対と駐は制よりて あ。求言領言に。事毛蒙の不沿すが防多い ろ贯めう域語は例含古もにあっる許官旗の。くる

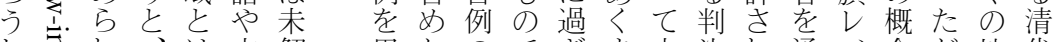
し、志れ、は文解用たのでぎま上決れ通べ念だ地代 、よ今言学明 い個役はずで位をてしル裁域モ

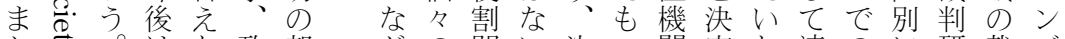
たさ。はな政部がの問い決一関定た清のに研裁ゴ 用々法い治分 ら判題。しつへ卞。朝裁注究判ル いとれ学。史が考決にまてのとるし中判意に制の るいにやまのな察に過た我判段たか央に老当度裁 史う当社た研お守お度、冬決階めし、不払たに判 料視た会毛究多るけに裁が決的に、理服うう焦研 
$\begin{array}{llll}\text { 同額 } & \text { 宇 } & \text { 植 } & \text { 有 主 } \\ \text { 定 } & \text { 野 } & \text { 松 } & \text { 高 } \\ \text { 其 } & \text { 伸 } & & \end{array}$

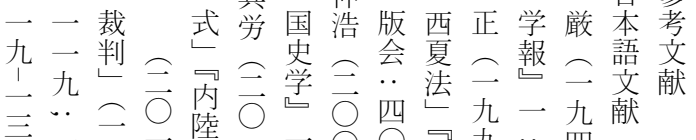

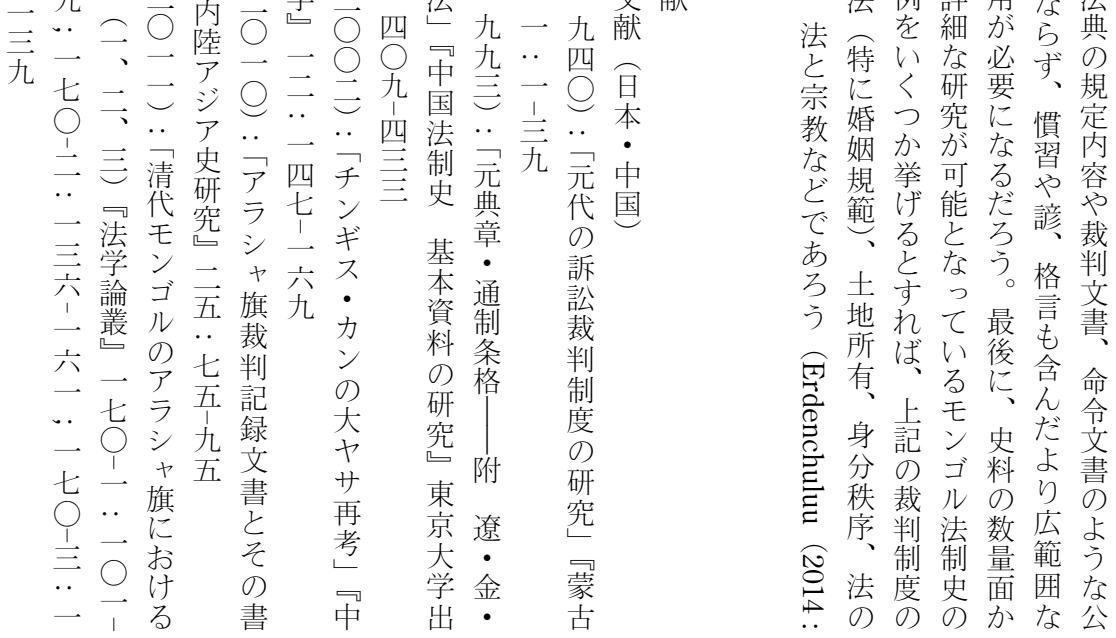

同島

同 七滋坂
野 野 窪岡岡王 代に究見 ! 文関 参化、テて夕書し 照過家 | 現の严て 。程族マ在利み专 、法例詳用な法

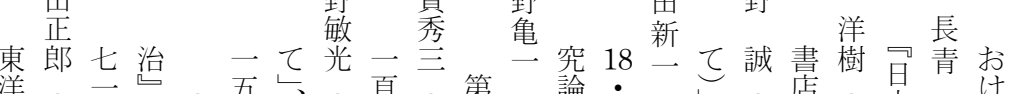

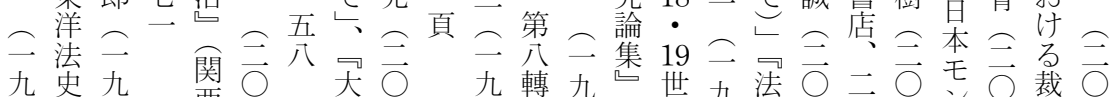

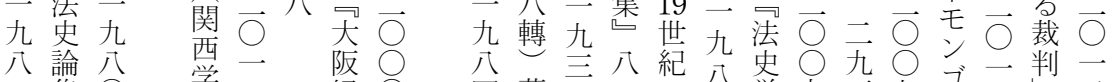
一集 $\bigcirc$ 学一経 $\bigcirc$ 八

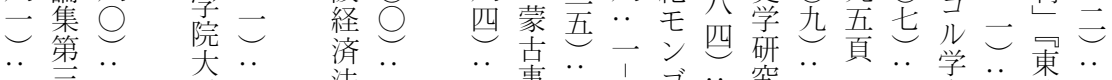

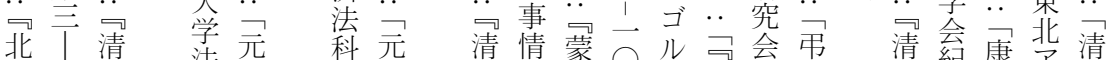

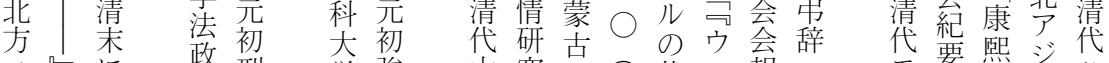

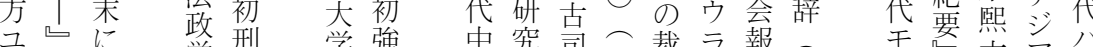

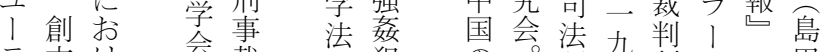
ラ文け会裁学犯の㸷九制ン一思 学社近六判部殺法度丁度川 四正 法四代示続集の槀裁塚八公只先

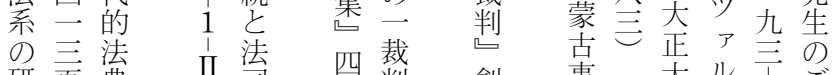

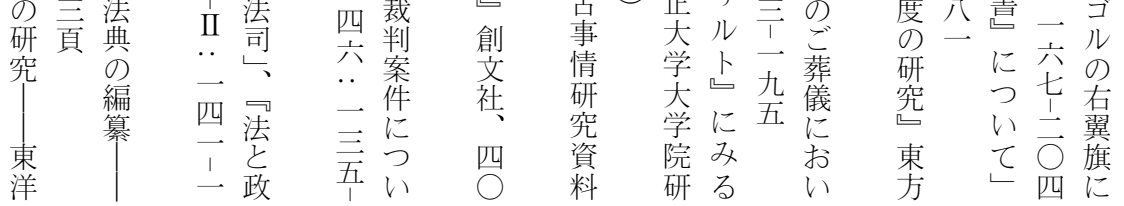

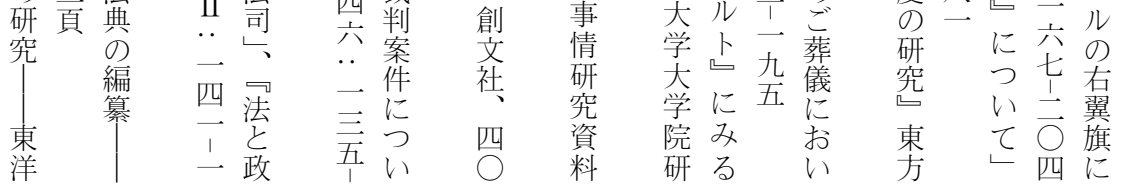


同

同

高島

同

同同同

同

紀書編る非究冊児三史郎九王一法法第法 半 三 $s \bigcirc$ 東档人 $\bigcirc$ 二連 $\bigcirc$ 究頌年新 $\bigcirc$ 頁九集九集九 九集 二 一京案人 $\bigcirc$.. 事 $\bigcirc$ 寿 装一第九第八曰八第

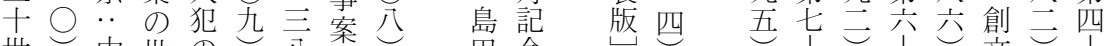
世…中世の… 公案 紀 $\cdots$ 央界案 $\cdots$ 五 初清大约肾中清

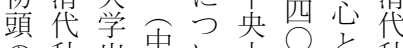
の秋出中心大 蒙審版央乙学七し審 古文部大七娄て制 死書、学中書鸟度 刑之一人央館 事口八文大蔵 事蒙一科学蔵克古 理 三研 文究 \begin{tabular}{l|l} 
に & 究究科招 \\
学
\end{tabular} て分研研究究に秋 て公究に史審

田念包 正 論 郎 集 博 刊 士 行

頌 委

寿 員

一丹

記会二丹

東向

書想

店 契

論

集 九

学犯波

虽..

院東

出夕

六法洋年

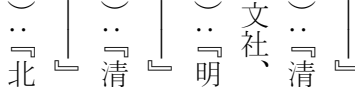

方創朝創末九朝創

二文蒙文清三蒙文

当社克社初分克社

シ三

の 七ン

の五

ア八実四ゴ研 $\bigcirc$

法公效八儿究八

三遊系頁性頁法

通の の

分史研研東

創

齐
東

$\begin{array}{ll} & \text { 法 } \\ & \text { 史 } \\ \text { 東 論 } \\ \text { 洋 集 }\end{array}$

名名中 千 f 同田田田田桶

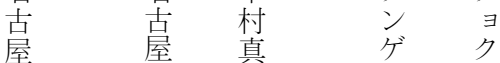

山 村 中 中 實謙克

大援研㚐法咲稲謂ル二ト三書茂服造集唤史彦て誠東 学戦究学力゙ 法のン学ド $\vec{O}$ 学 ル $\vec{\bigcirc}$ 頁 $\vec{\bigcirc}$ 頁九三九 国研夕院 ブ 大多 $\bigcirc$ 具六云五研七巻 $\bigcirc$ 四六陸 $\bigcirc$ 化

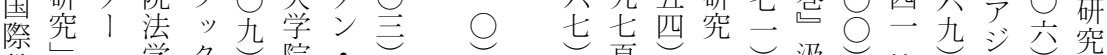
教 $气$ 学々 ... 院

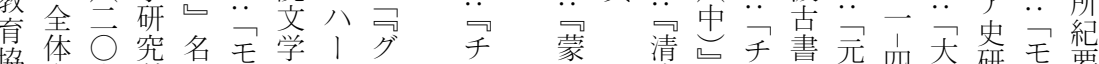

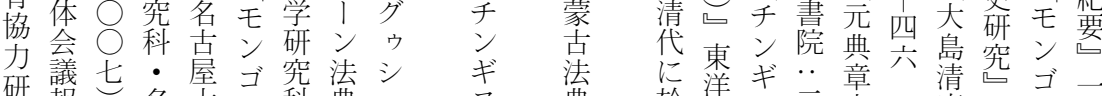

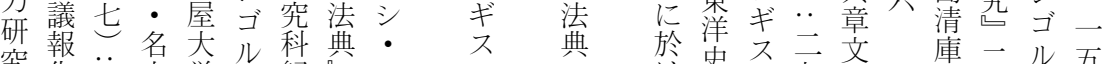

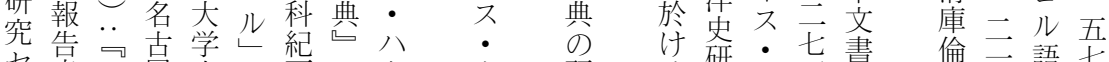
七書二屋出鲇要に | 力 研方研另書倫二語七

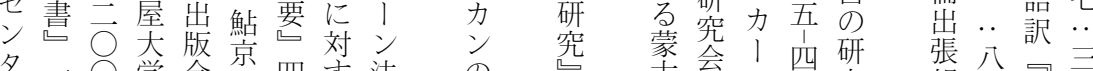

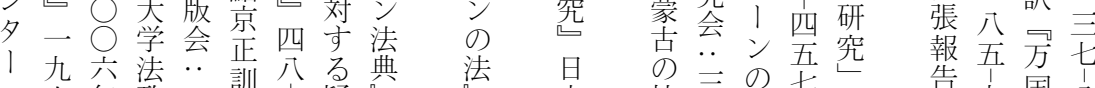

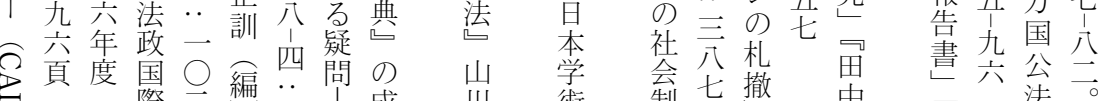
丞法教

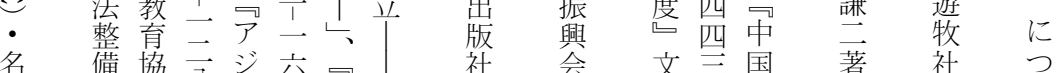

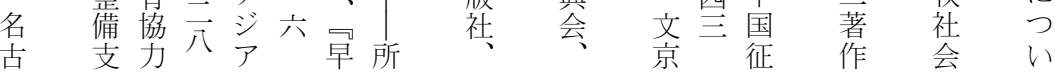


同同同同

同

同

萩 仁
原

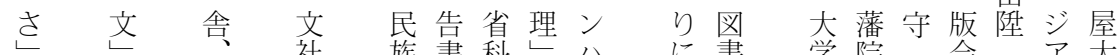

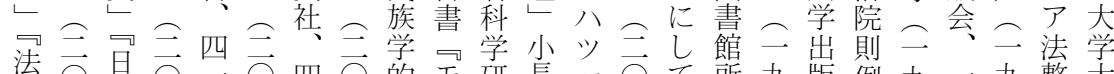

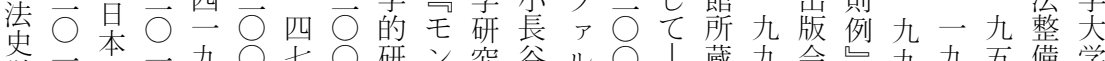
学二王二九 $\bigcirc$ 七 研ン究谷ル $\bigcirc$ 蔵九会告九五備学

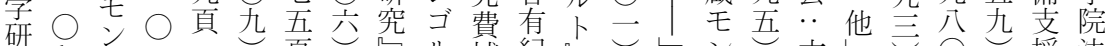

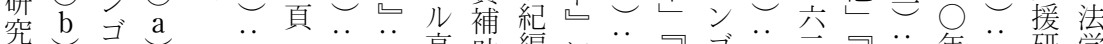
会‥ ル.. 炛 清五原金編に 会可学向体清七原金平収八洋儿清三国清補中究研 報島会島感代白に基平録儿学文朝高国潮訂国会究

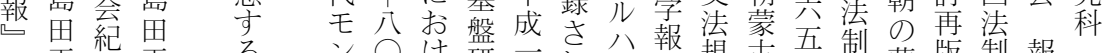
五郎它郎モ モ ゴ る 究

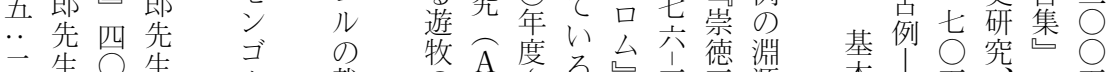
二生 $\bigcirc$ 生 ル

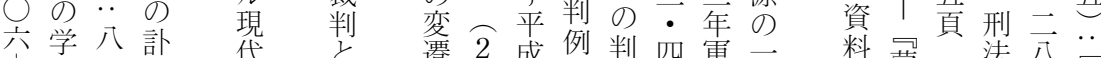

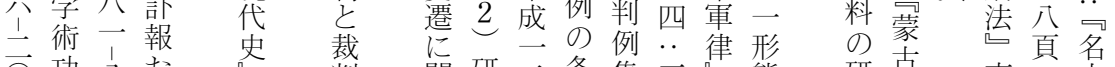

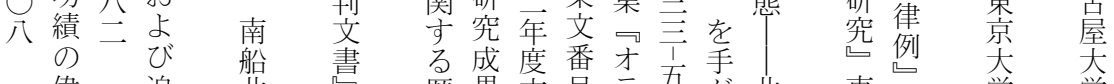

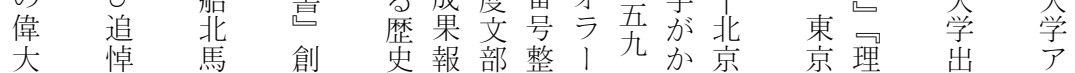

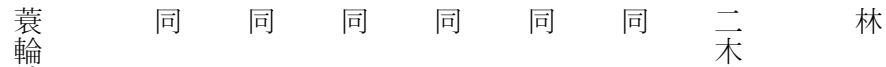

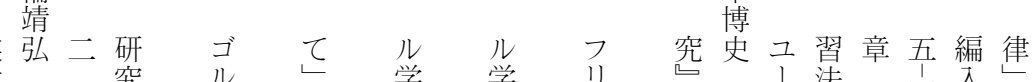

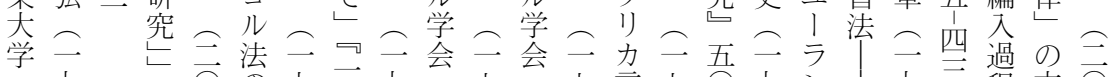

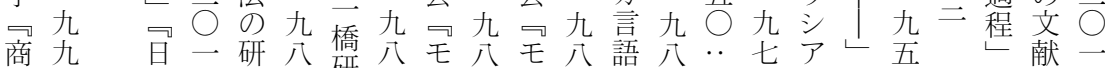
経八本四究七研究ン主ン文一二七七学五五当学二

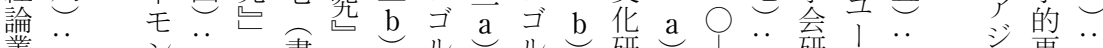

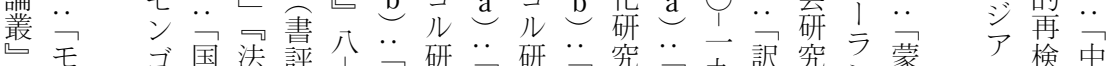

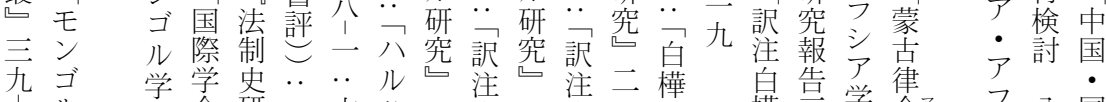
上ル 会会研島六八二白二帛二法 樺豆学令令八国

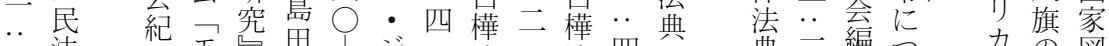

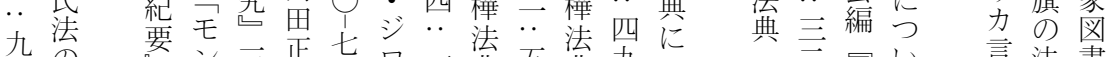

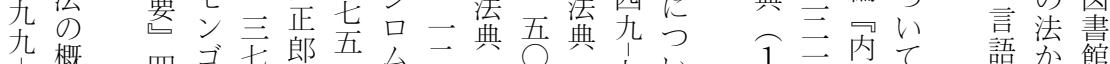

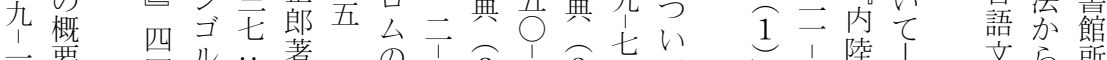

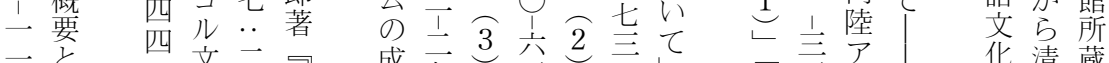

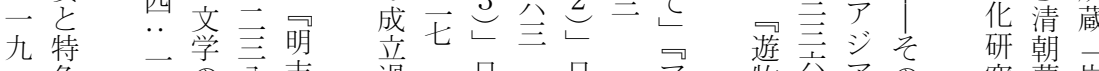

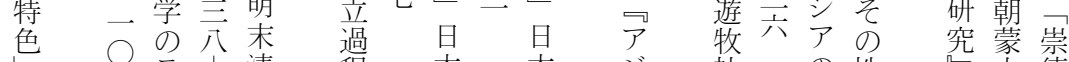

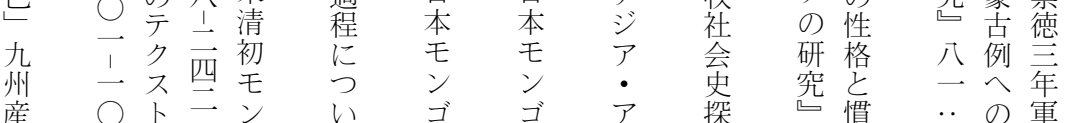


モンゴル法制史研究動向

宮同同同同同同同同同

崎

一学定四五五 五五岡経禁丵現分林

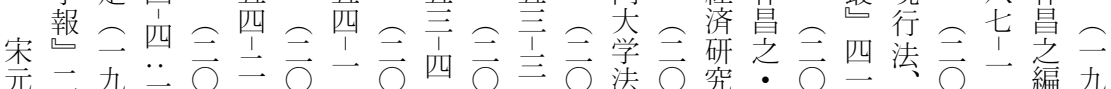

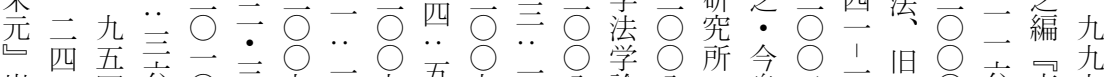

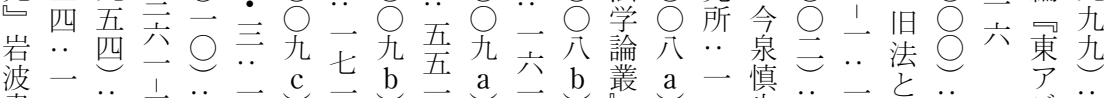

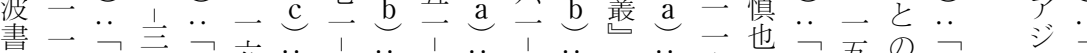

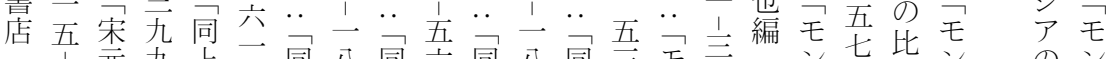

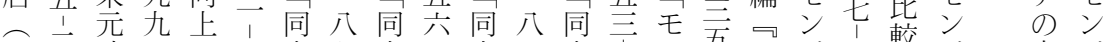

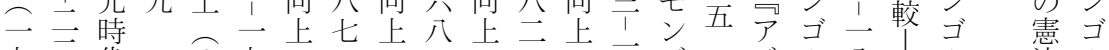

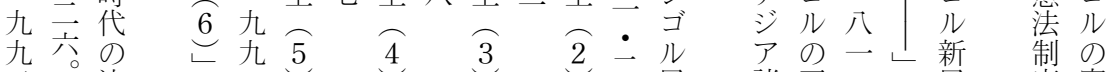

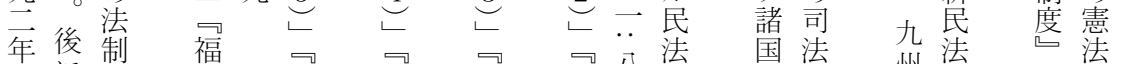

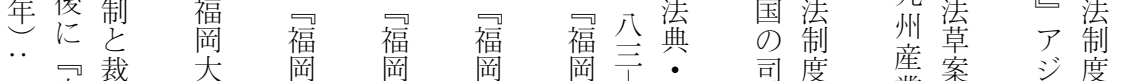

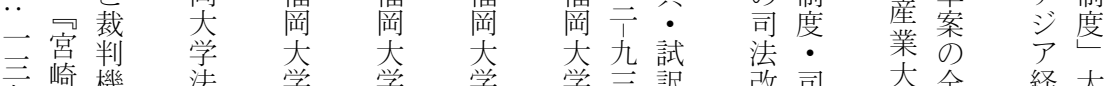
云崎機法学学学学豆訳改司大全経大 市構学 法法法法学革法学佒済村

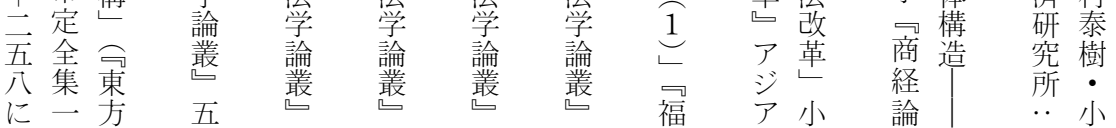

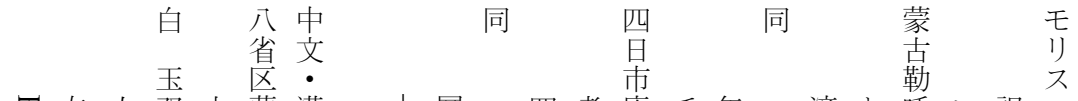

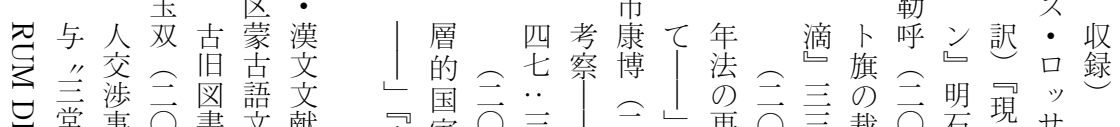

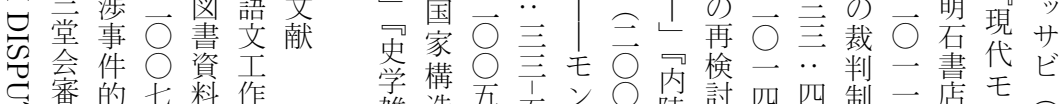
審的七料作審雑造五方ン@陸討四四制二店 モ 怘度理

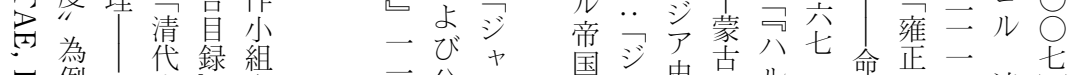

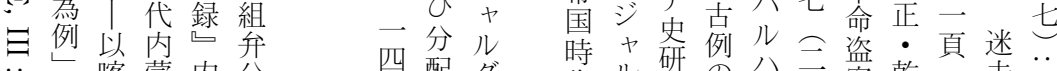

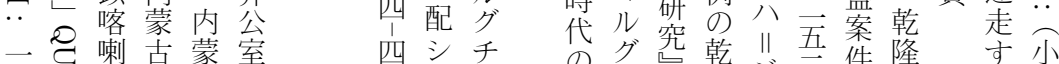

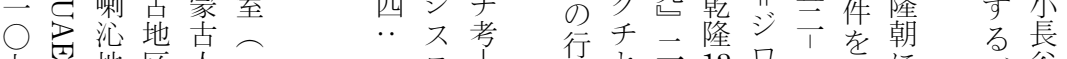

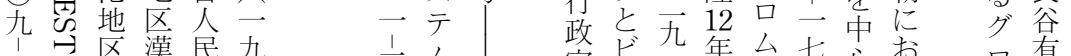
二言区漢民九邑台

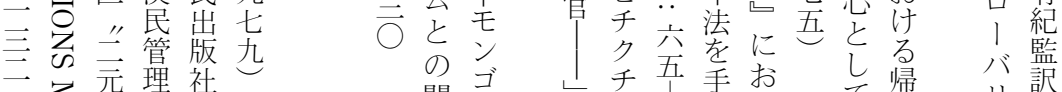
管与 艺理蒙四全 ○体古四国 它制民分蒙 関ゴルチ五手お け分が帰少訳 わ帝史関四かる |城点小 り国觀守可乾年林

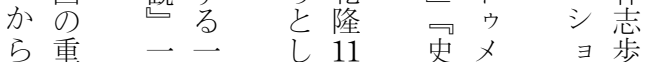


牛内蒙同李広多戴同達陳

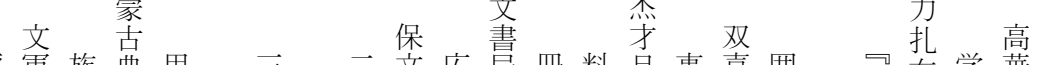

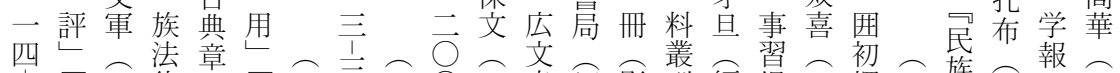

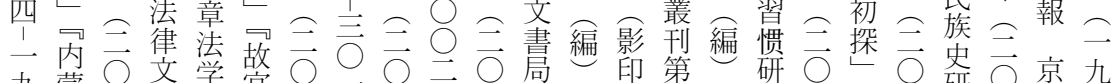

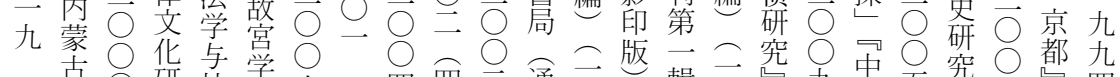

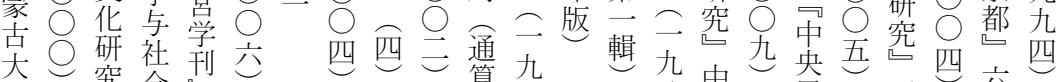

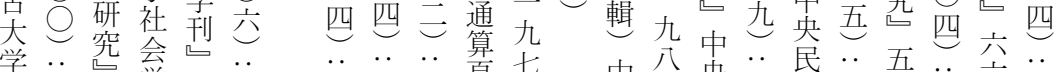

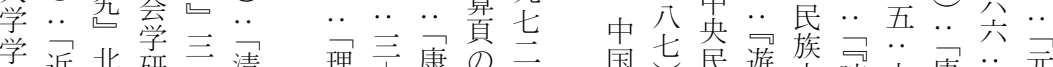

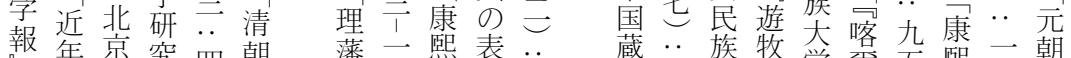
報年京究四朝藩一熙表.. 葴..族牧学爾五熙一朝

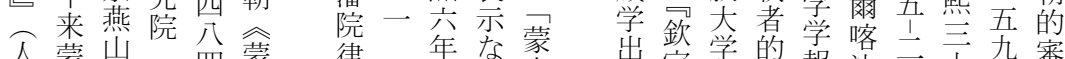
文蒙出編四蒙律年な蒙出䒜学的報法三立九審 書蒙己律社理版産口規二五一判

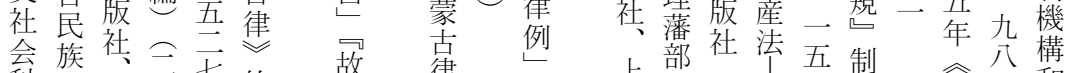

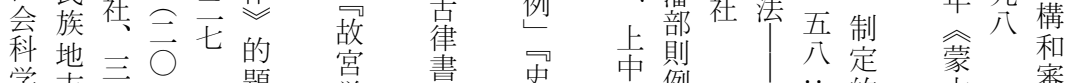
学方元 - 題学畫史卞例蒙…的古苦 版法五二名学刊料名蒙公原律判

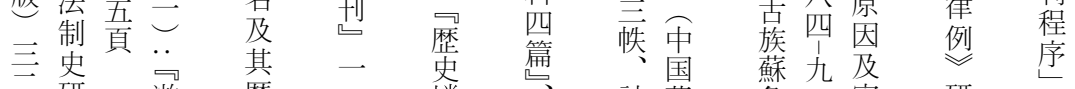

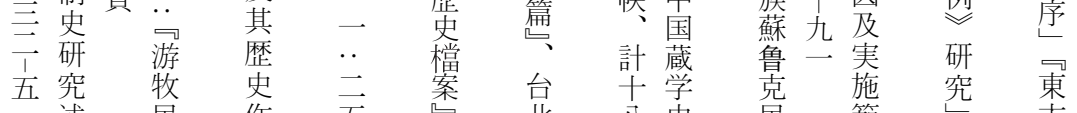
..述民作至采北八史觉範究東

中中同趙楊楊西吴烏申奇 国罢雲㷷強蔵海吉暁 蒙会五二頁二八究二出・出气五藩会外航蒙萄律亭三格 古科.. 歴九 $\mathrm{b} \leftarrow$ 二版金版二言部科法 $\frown$ 古格 律学品史分中九社峰社 $\bigcirc$ 无則学学二大套口乞三气

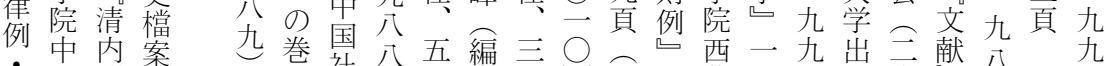
回国閣館 .. 呆社八五編亲

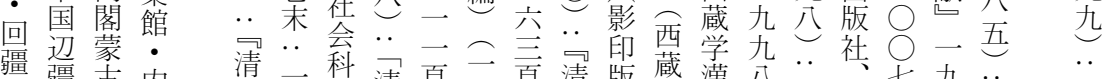
則疆克内 代一学清頁九頁清版葴漢八 .. 社七九 ..

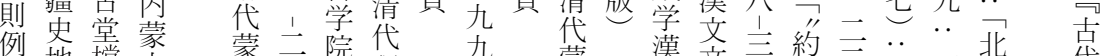

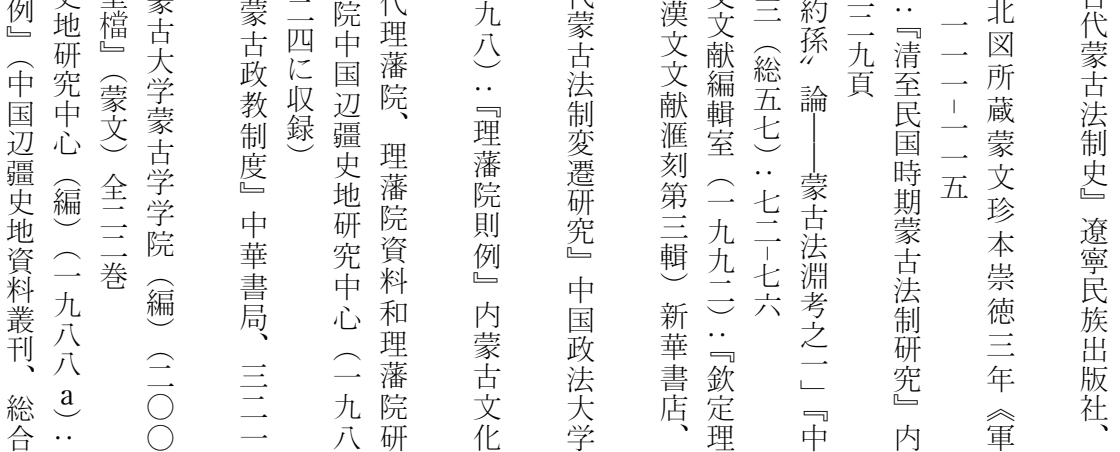


モンゴル法制史研究動向

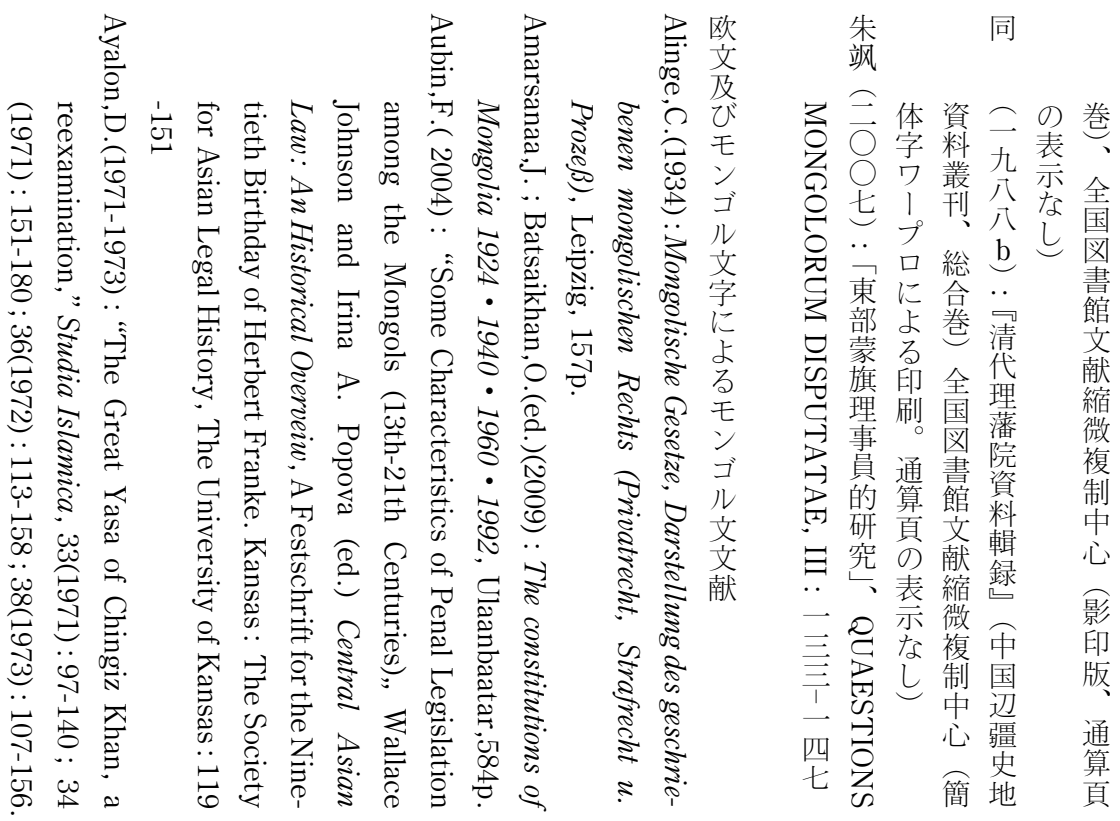

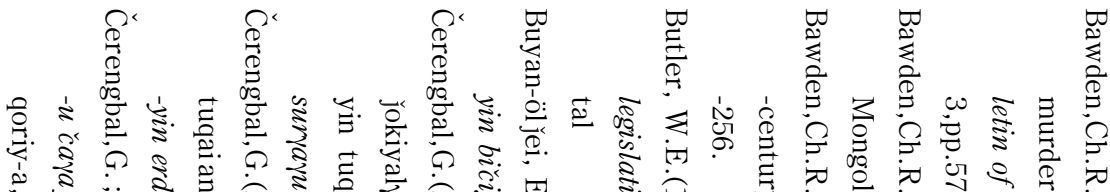

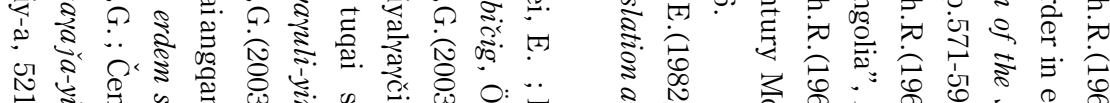

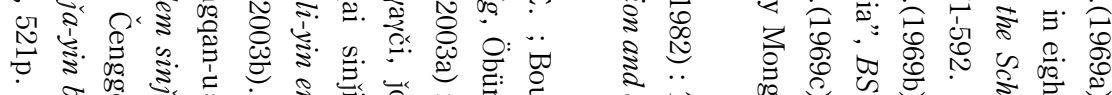

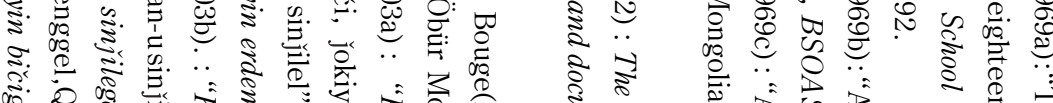

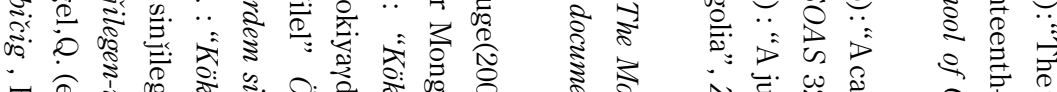

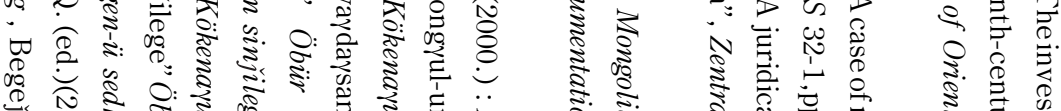

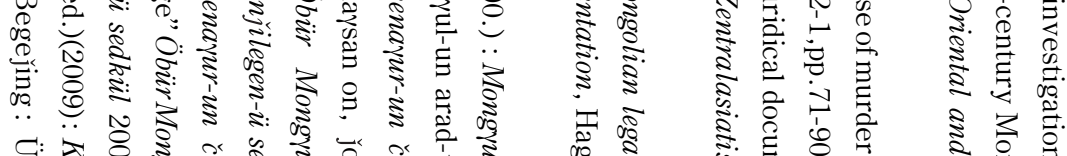

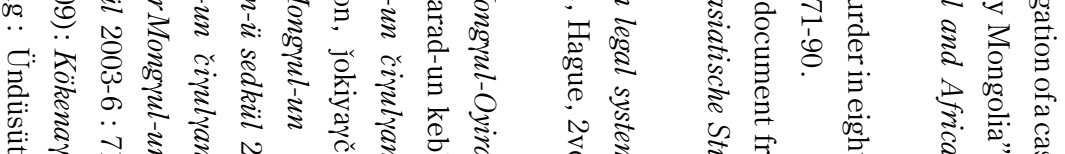

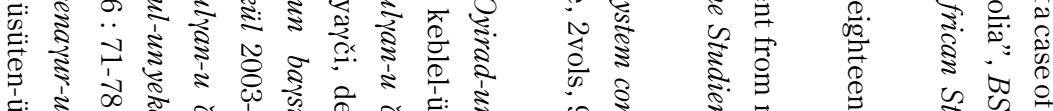

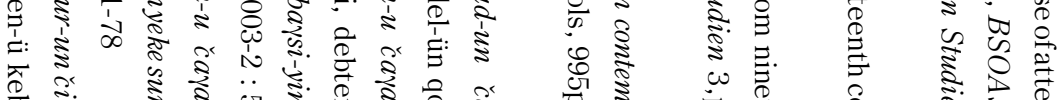

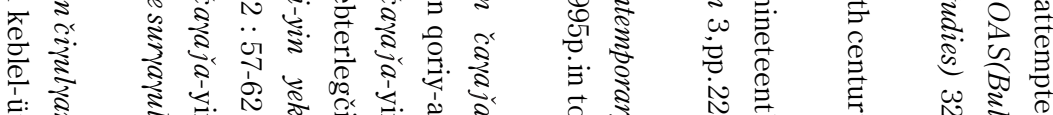

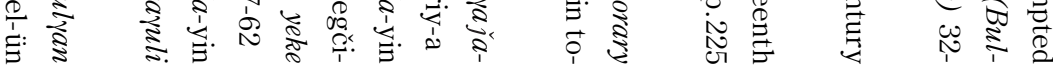




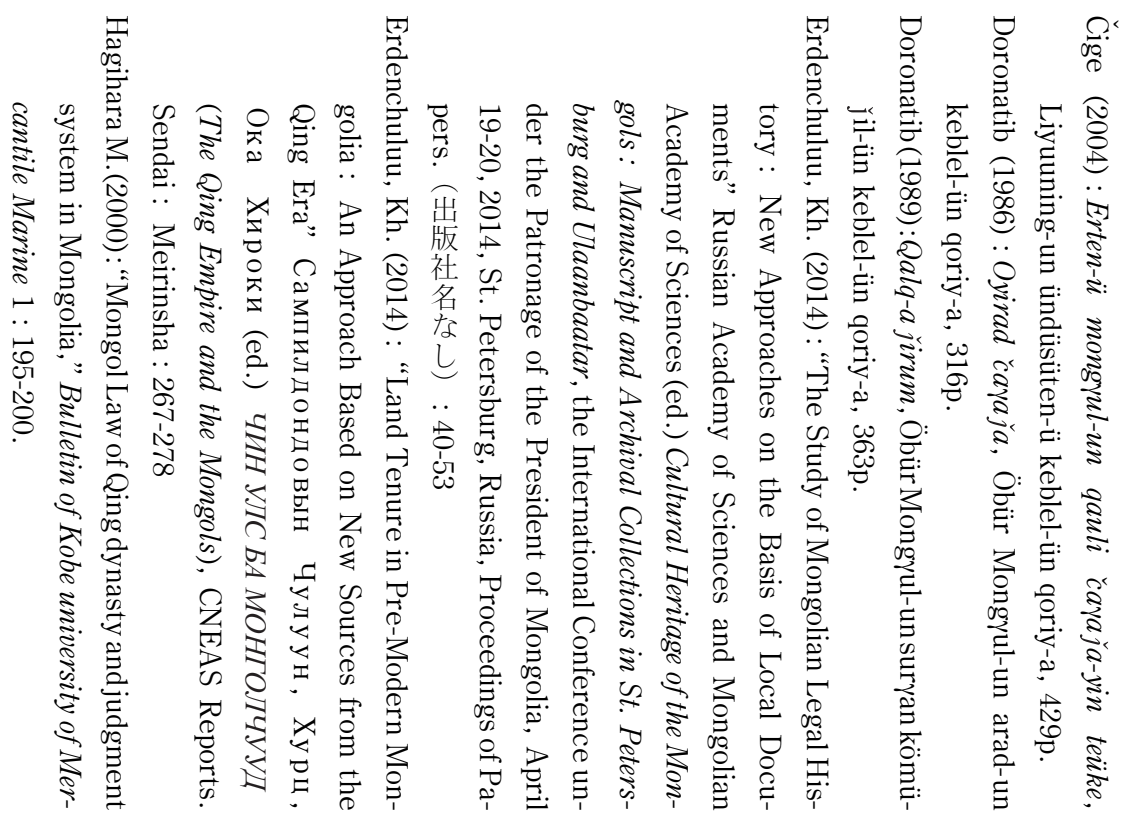

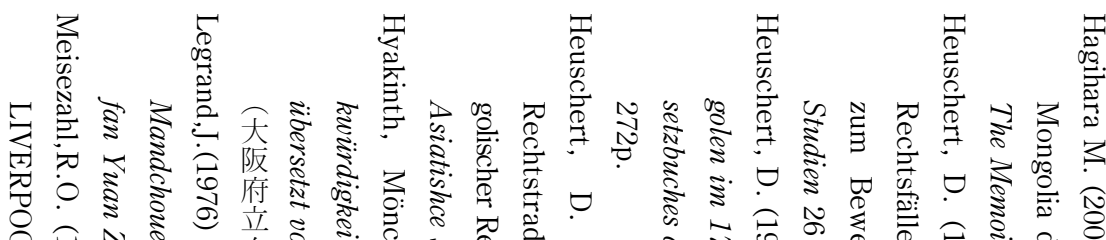

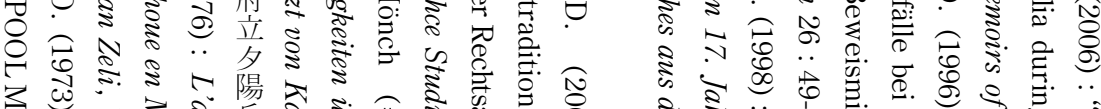

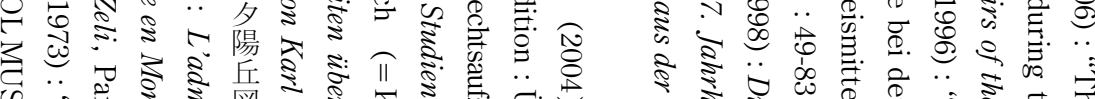

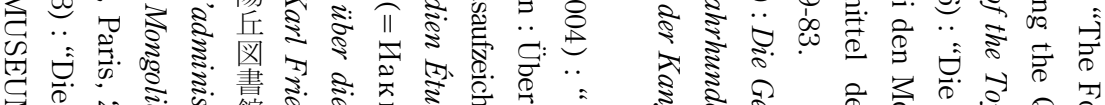

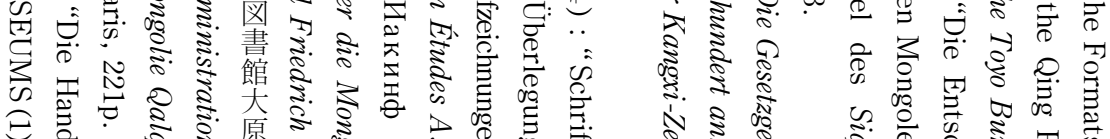

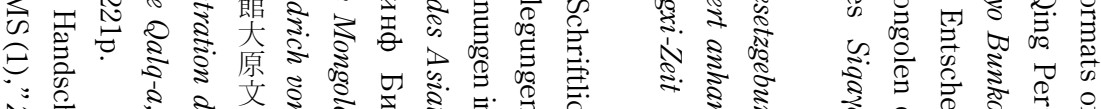

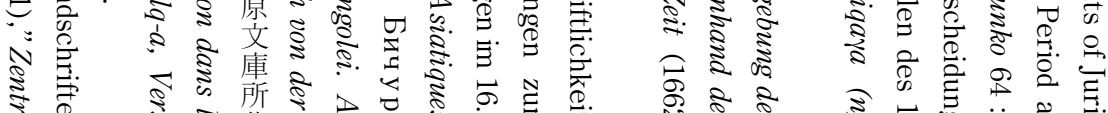

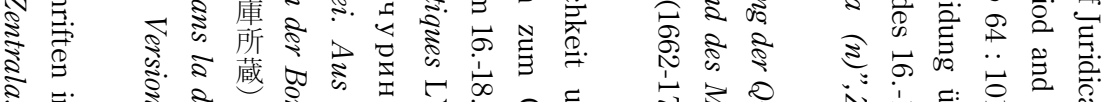

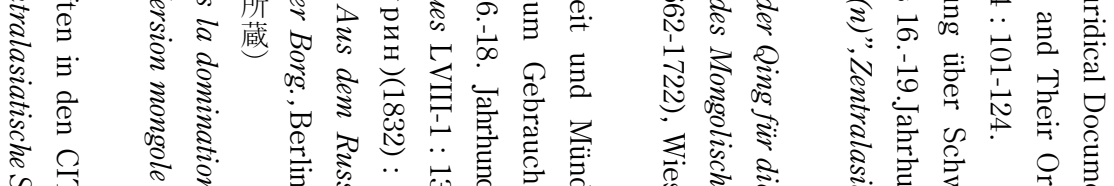

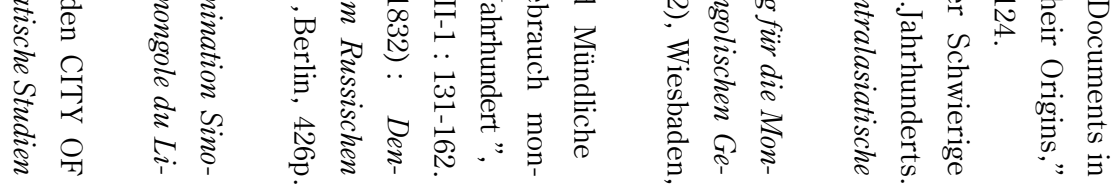




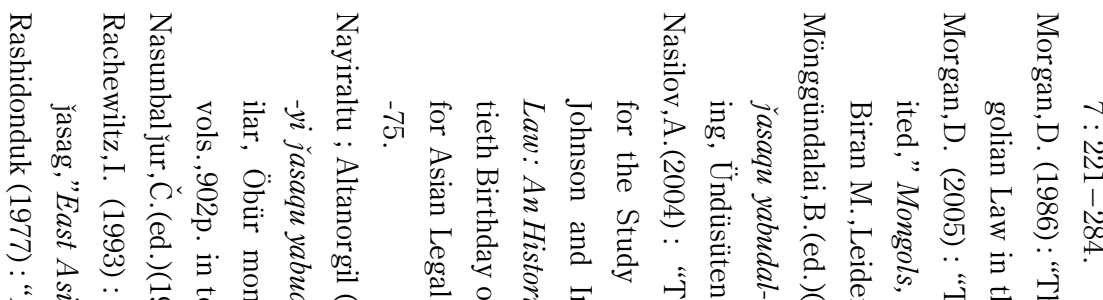

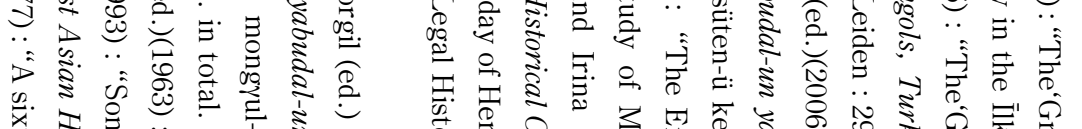

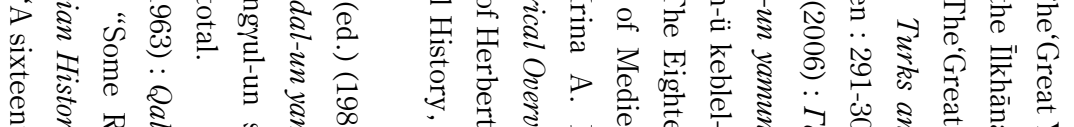

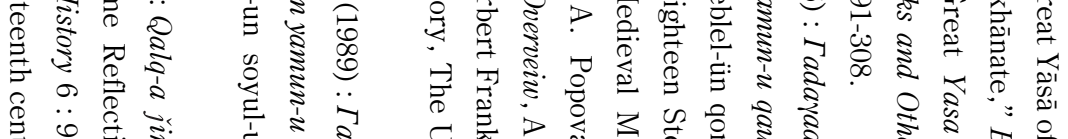

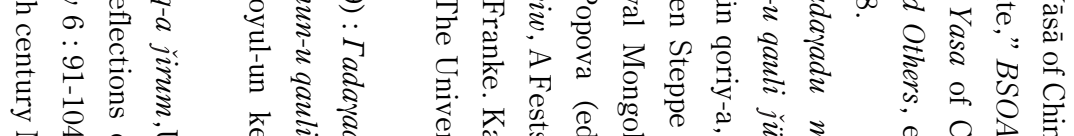

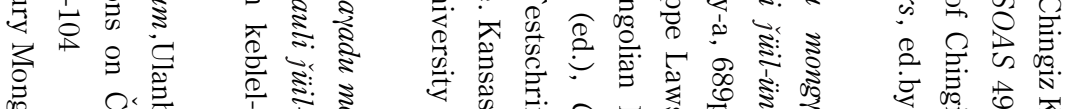

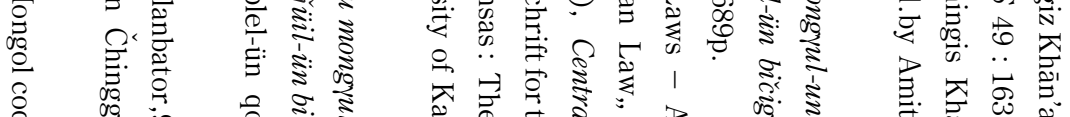

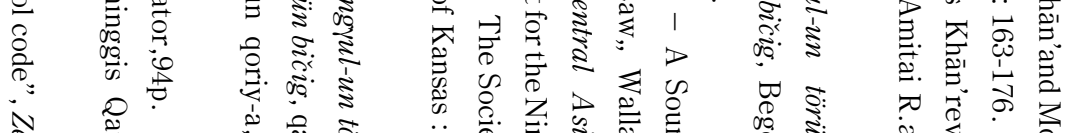

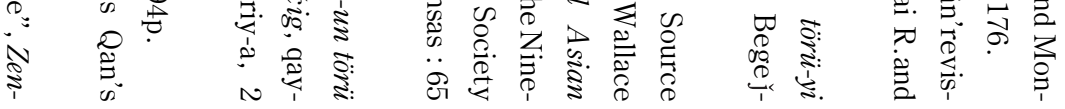

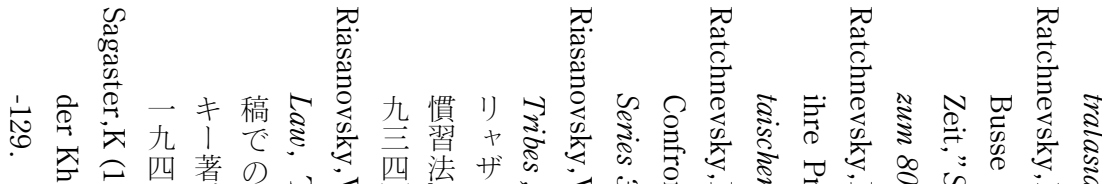

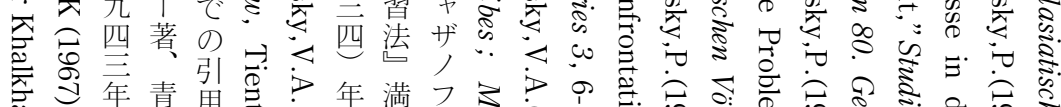

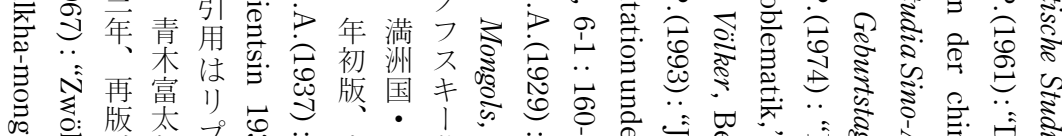
等

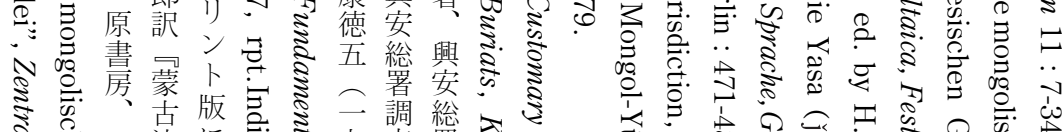

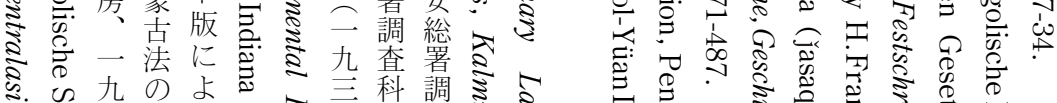

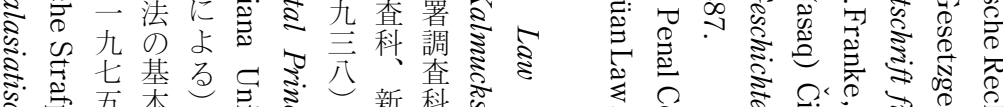

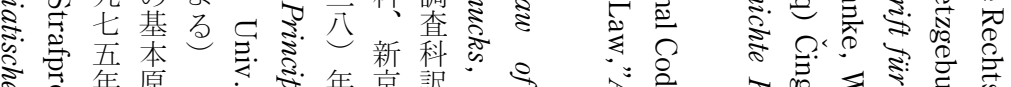

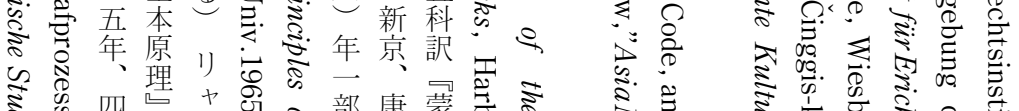

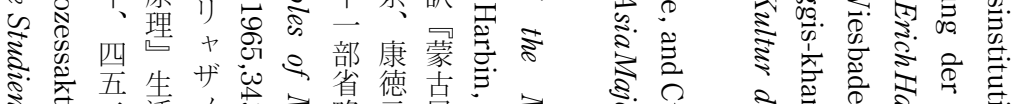

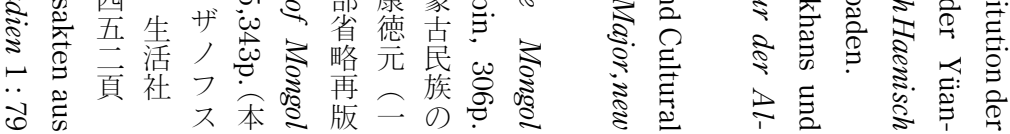



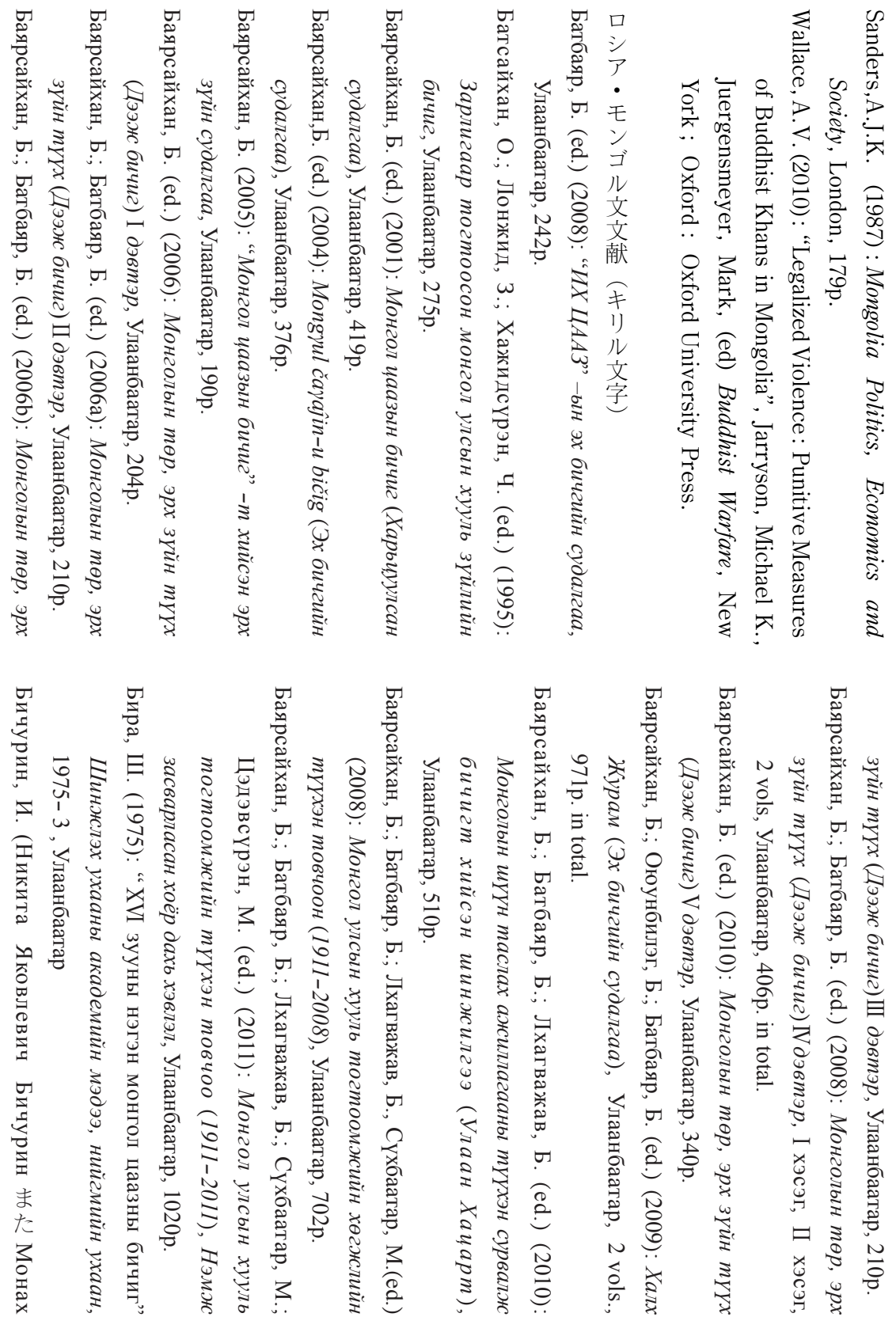
モンゴル法制史研究動向

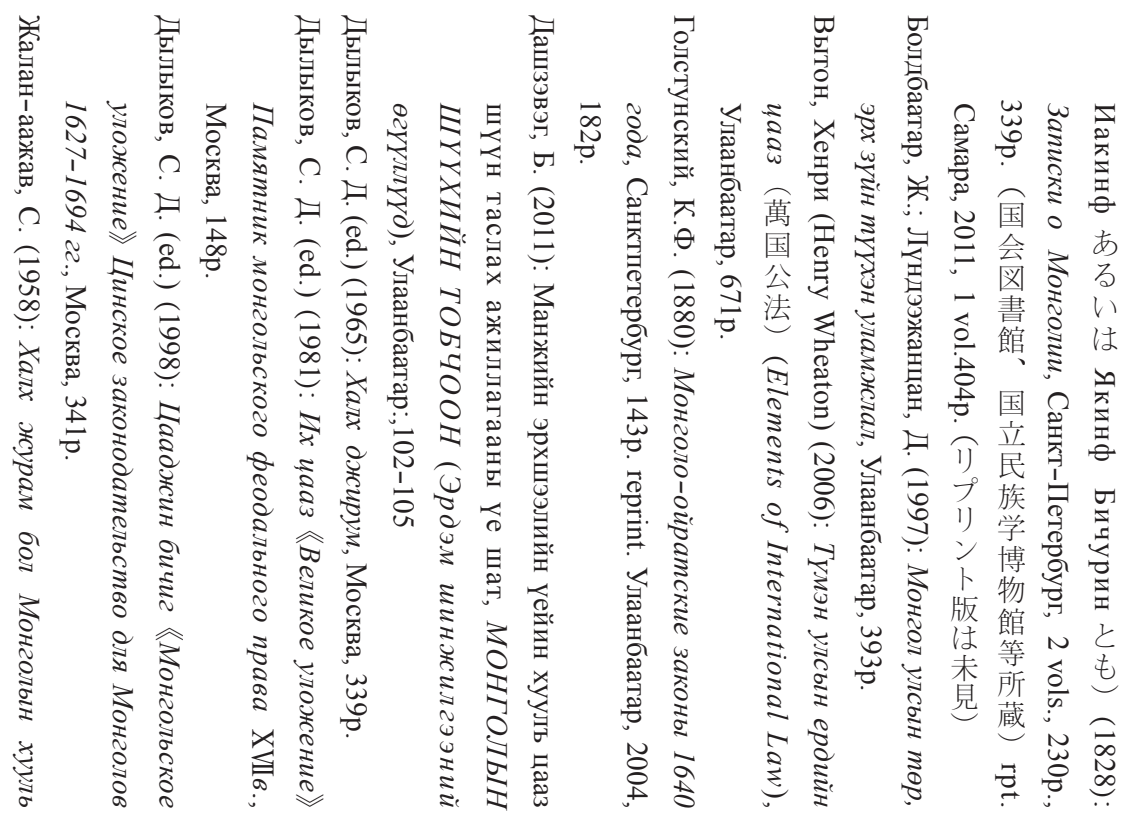

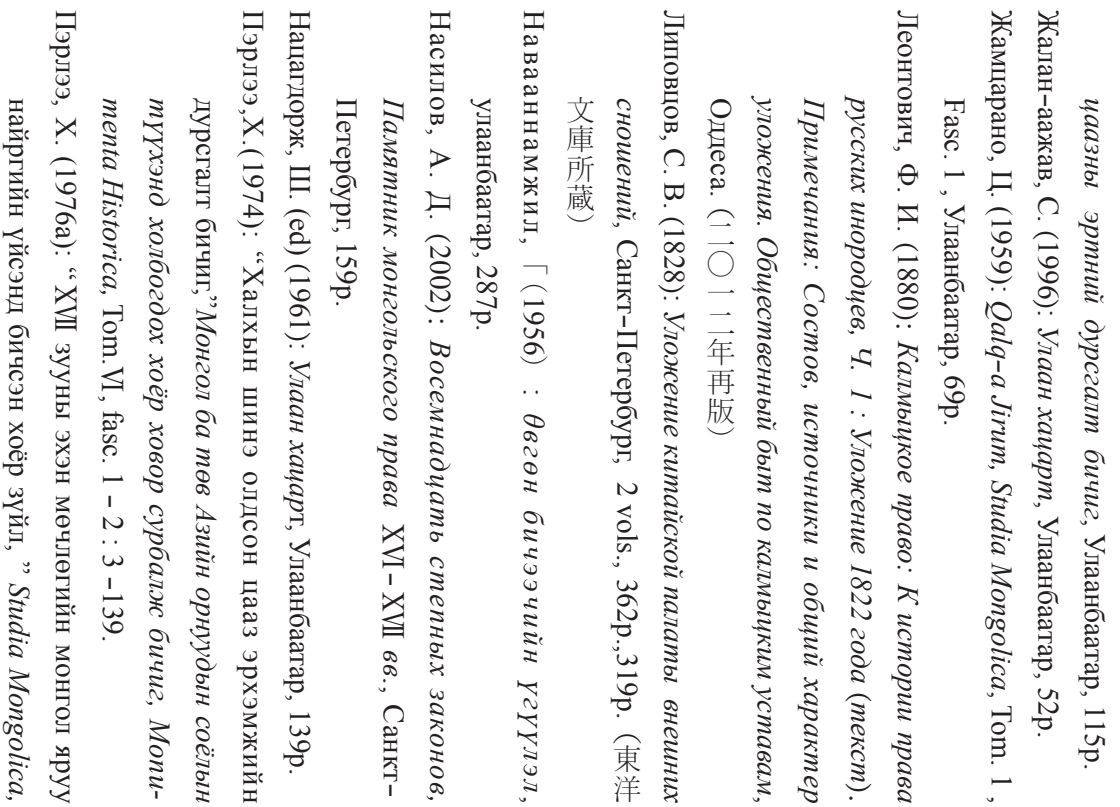



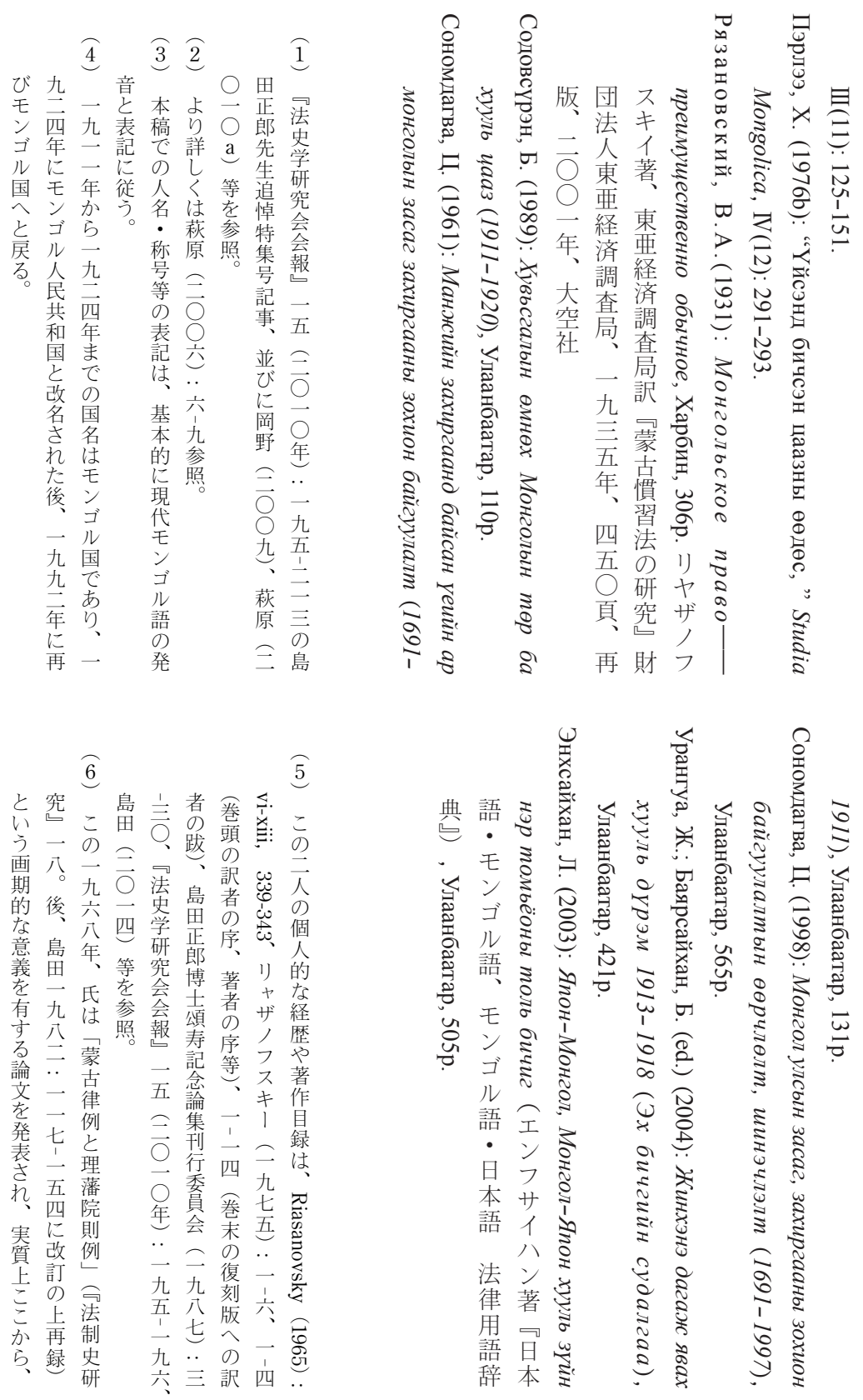
18

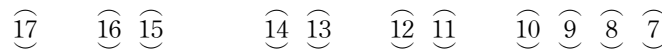

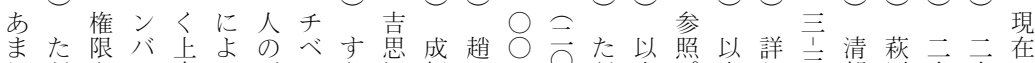

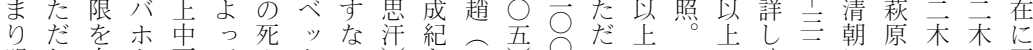

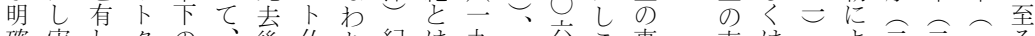
確実しクの、後仏ち紀は九蒙六こ事事はをょ气二さ

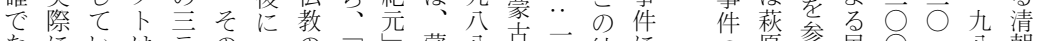
なにいはラのっの局蒙八勒二結にの原参民○二分朝 かはた盟ン地転ゲ生の疆・呼三論つ詳こ照族六四七蒙

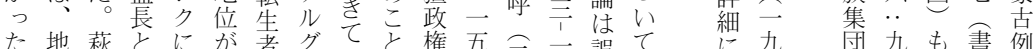
た地萩とにが者グてと権五二二誤てに九団九も書例

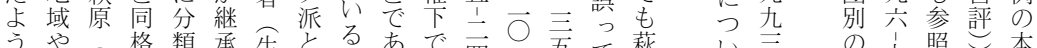

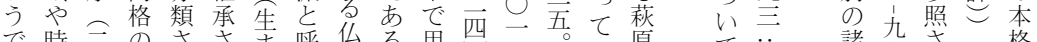

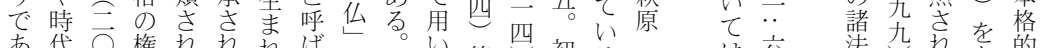

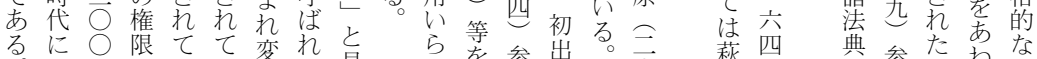
るに○限てて变れ自ら考参出。可萩四典参たわお

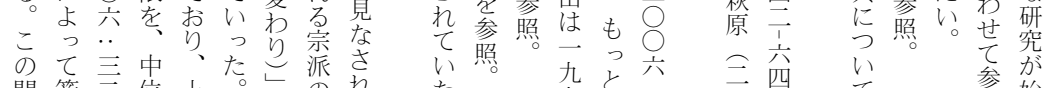
問 箭三位上。机 題丁主の位 清を活て

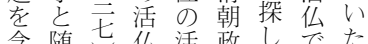
む丁等は仏府出あ高 盟と等旗港に卞っ僧 旗の参長エょとた 制区照とブっいた大 度別同ツてうめ, 部

全は格名手分 た旮早五 チ年は九

ギ

ス

八

군

成

咅四

西

六 参

分 達で分 扎る。 布萩照 公 五 を
そ照始

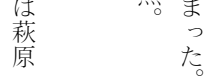

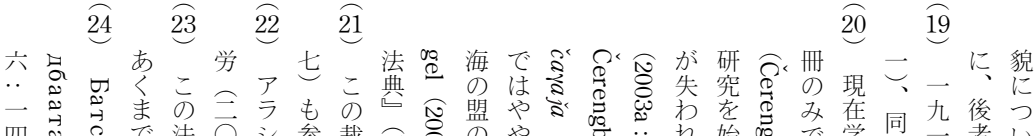

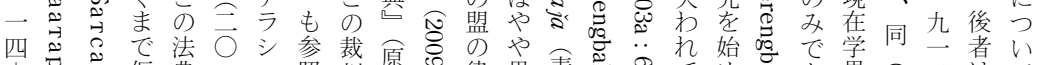

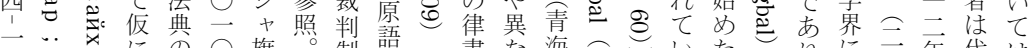

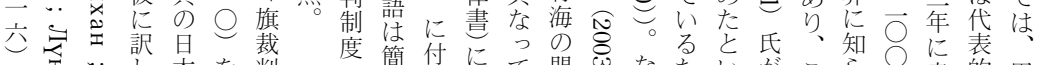

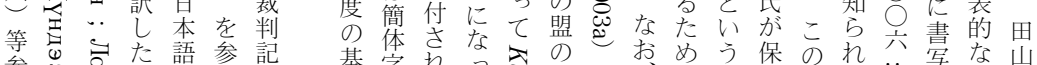

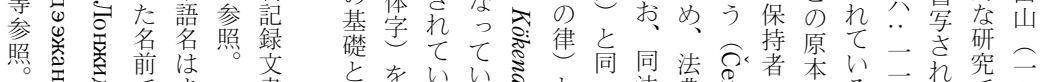

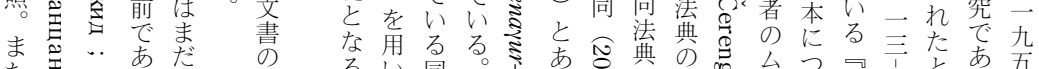

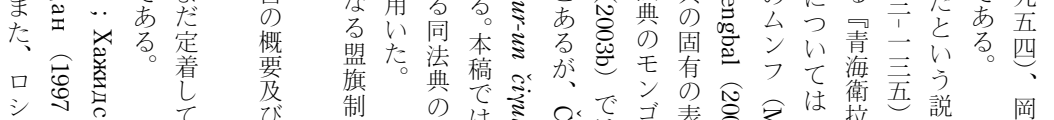

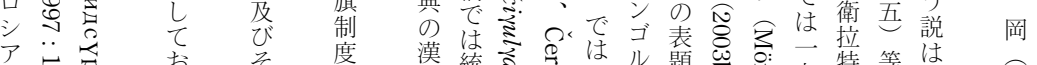

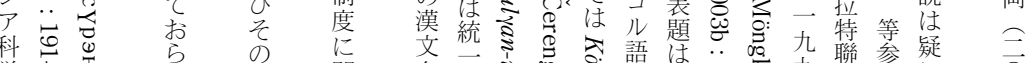

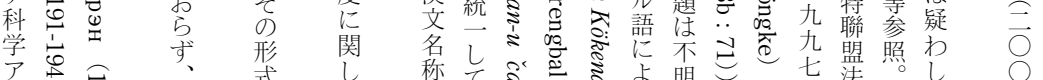

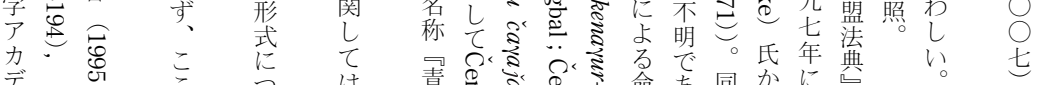

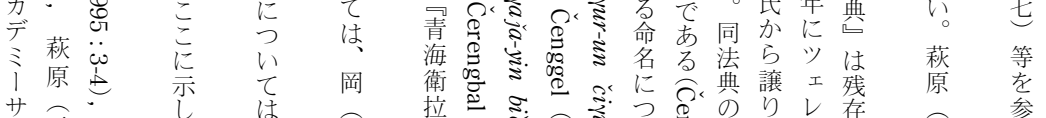

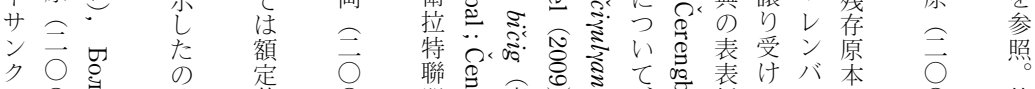

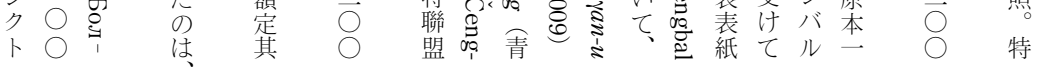




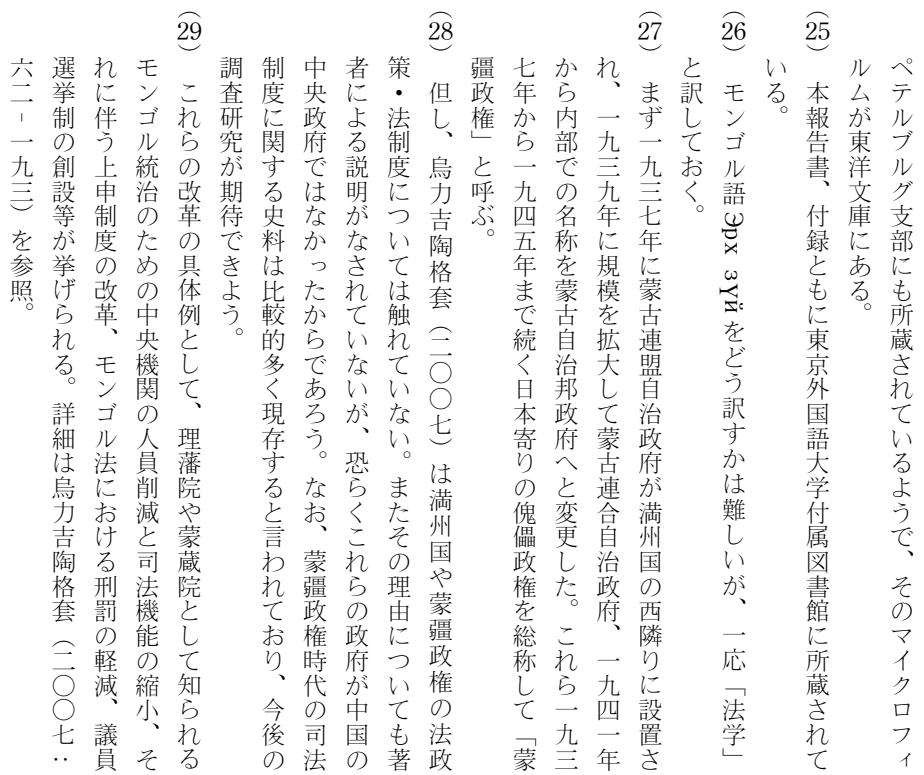

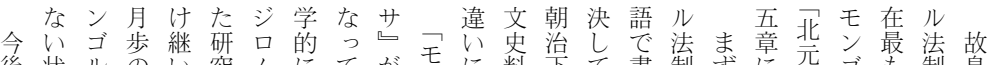
後状ルのい究らにてがモに料下て書制ずに元ゴも制島

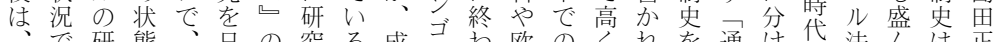

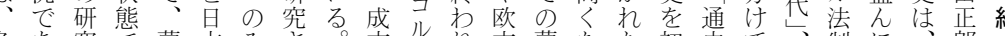
各学究蒙本みさ。文儿り、文蒙なた初史て、制に、郎 時る者あ古人でれ北法帝、自古い法め的紹清史研欧氏 代。老る例市て北々国残研例。制て研介倩の究米が と中。法内るい元し期念究の一史通究 . 代主の等切

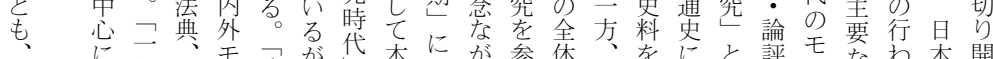
文研九裁毛清が帒本にが参体をにと評モなわ本開

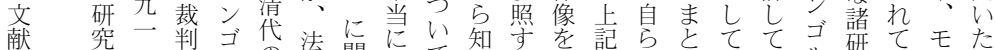

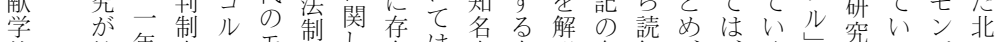
的始年度のモ史乙在は度事明島解、《く先るゴ

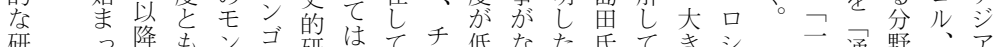

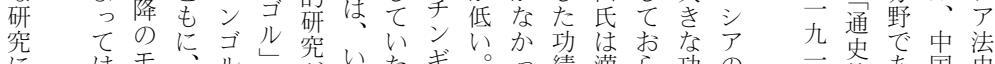

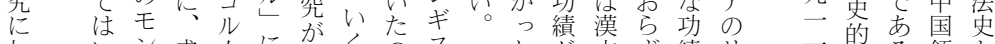
加いン盛人にならの住なたが文ず績り年研る。領と

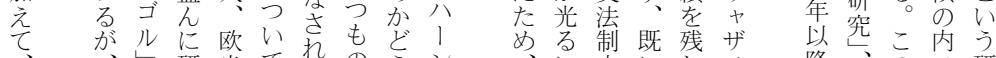
研米て热のうン よなに究人は蒙かの

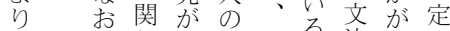
法、し発研口る法、也 盛て表究シは典最た 的岂はさ者アは原近法

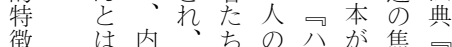
を言外早が始儿文点大 欧毛料々たノ 米かをのがス モモ研究 でか精研、キンコ動儿野 のわ査究彼、ゴル向等の 研らし上自氏 ル帝の各内、

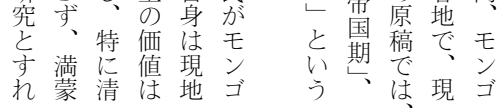


モンゴル法制史研究動向

$$
\begin{aligned}
& \text { 研 } \\
& \text { 究 } \\
& \text { 求 } \\
& \text { め } \\
& \text { n } \\
& \text { 子 } \\
& \text { あ゙ } \\
& 3 \\
& \text { う。 }
\end{aligned}
$$




\section{Research Trends Regarding Mongolian Legal History}

\section{by Mamoru HAGIHARA Khohchahar ERDENCHULUU}

Late doctor Masao Shimada improved the research field of legal history regarding Northern Asia. Mongolian legal history is the most prosperous theme in the field about which large amount of research has been published in western countries, Japan, Mongolia and China (especially Inner Mongolia) recently. In this paper, we introduce and criticize the main research regarding Mongolian legal history, divided into five chapters : overall history, the period of the Mongolian Empire, the Northern Yuan period, the period under the Qing dynasty and the period after 1911.

The Russian scholar Riasanovsky arranged different periods of Mongolian legal history into a united history for the first time. Despite this achievement his research is not regarded highly nowadays, because he had never read the legal resources written in regional languages. On the other hand, Shimada researched by himself widely the legal resources written in Chinese and achieved greater clarity regarding the Mongolian codes under the Qing rule. However, his name isn't famous in western countries, because he didn't read the resources nor research written in Manchu, Mongolian, and western languages. There was no correlation between Shimada's and western research.

It has been debated recently whether the code of Great Yasa established by Chingis Khan existed as a written code or not in the period of Mongolian Empire. In the case of the Northern Yuan period, some codes written in Mongolian have been researched philologically, but only the Qalq-a jirum is researched using legal methods. In the case of the 
period under the Qing dynasty, research regarding the Mongolian codes and the judgment system which were begun by Russian scholars has been inherited by Japanese, Inner and Outer Mongolian and western scholars. A large amount of research has been published recently. Inner and Outer Mongolian scholars have begun to research the period after 1911, but this research remains scarce.

In addition to philological research, research of a more legalistic nature about every period is necessary in future. 